Universidade de Brasília

Faculdade de Medicina

Programa de Pós-Graduação em Ciências Médicas

GABRIEL GINANI FERREIRA

AVALIAÇÃO IN VITRO DE EFEITOS ANTI-INFLAMATÓRIOS DE EXTRATOS DE POUTERIA TORTA (MART.) RADLK E POUTERIA RAMIFLORA (MART.) RADLK

Brasília, DF 
GABRIEL GINANI FERREIRA

\section{AVALIAÇÃO IN VITRO DE EFEITOS ANTI-INFLAMATÓRIOS DE EXTRATOS DE POUTERIA TORTA (MART.) RADLK E POUTERIA RAMIFLORA (MART.) RADLK}

Dissertação de Mestrado apresentada ao Programa de Pós-Graduação em Ciências Médicas, da Faculdade de Medicina da Universidade de Brasília como parte dos requisitos necessários para obtenção do Título de Mestre em Ciências Médicas, Universidade de Brasília.

Orientador: Prof. Dr. Riccardo Pratesi

Co-orientadora: Profa. Dra. Yanna Karla de Medeiros Nóbrega

Brasília-DF

2016 


\section{DEDICATÓRIA}

Ao meu avô, José de Abreu Ferreira (in memorian), pelo exemplo de vida, ensinamentos e apoio nas horas difíceis. 


\section{AGRADECIMENTOS}

Todo trabalho é resultado de um árduo teste de dedicação, comprometimento e suor. O tão aspirado sucesso no final dessa jornada é também compartilhado por todos que, indiretamente ou diretamente, foram indispensáveis durante a caminhada, criando as condições para que os objetivos pudessem ser alcançados. Assim sendo, neste trabalho agradeço à:

Toda a minha família, em especial meus pais, Verônica e Claudio, e irmão, João Pedro, que estavam comigo em cada passo até aqui, me motivando diante das dificuldades enfrentadas.

Ao meu orientador e minha co-orientadora, Riccardo Pratesi e Yanna Karla Medeiros de Nóbrega, que aceitaram me orientar, me deram todas as possibilidades para me corrigir quando errei e possibilitaram o crescimento obtido durante esse período de trabalho.

A toda equipe e amigos do laboratório, que me acompanharam nos longos experimentos. Me ensinaram como realizar trabalhos científicos de qualidade, além de me aconselhar e incentivar depois de tantos ensaios sem sucesso. Agradecimentos, em especial, a Isabella Márcia Soares Nogueira Teotônio e Patrícia Fritsch, que me ajudaram a superar os erros e com seus ensinamentos possibilitaram a conclusão dessa dissertação (ao preço de chocolate Cacau Show 70 \%) e a Carolina Pereira da Cruz, que manteve a cultura de células quando precisei.

Aos amigos que vivenciaram comigo essa fase, escutando quando precisei e interessados em saber o andamento do trabalho, em especial Brisa Goulart, Guilherme Hirata, Júlia Matos, Melissa Merlone, Rafael Matos, Victor Fernandes, entre tantos outros.

Aos meus queridos estagiários no Colégio CEP Saúde, Diogo do Nascimento, Eduardo Carvalho, Clara Luna, Sabrina Amaral, Marcelo de Melo e Victor Honorato, que me possibilitaram mais tempo de dedicação a este trabalho.

Ao coordenador pedagógico do colégio Olimpo Bruno Filipe Cirilo de Carvalho, que foi compreensivo durante todo o período em que precisei me dedicar à pesquisa.

Ao Laboratório de Produtos Naturais da Faculdade de Ciências da Saúde da Universidade de Brasília (UnB), por ter cedido os extratos utilizados, possibilitando a pesquisa.

A todos professores e mestres, inclusive aqueles que, infelizmente, não estão mais aqui, que de uma forma ou de outra me deram o incentivo para escolher essa profissão.

À Coordenação de Aperfeiçoamento de Pessoal de Nível Superior (CAPES) pelo suporte financeiro que possibilitou a pesquisa.

Enfim, a todos aqueles que me ajudaram nessa trajetória. 


\section{EPÍGRAFE}

"Ciência se distingue de todos os outros ramos de procura humana por seu poder de provar e entender o comportamento da natureza em um nível que nos permite predizer com acurácia, se não controle, os resultados de eventos no mundo natural. Ciência especialmente melhora nossa saúde, nossa riqueza e nossa segurança, que é maior hoje para muitas pessoas na Terra do que em qualquer outro período na história da humanidade." 


\section{RESUMO}

O processo inflamatório é um mecanismo complexo, composto por diversos tipos celulares e altamente regulado, servindo como uma linha de defesa primária na resposta imunitária contra diversos estímulos. Essa resposta, normalmente, é benéfica ao organismo, sendo autorregulada, reestabelecendo a homeostasia em pouco tempo, nesses casos classificada como inflamação aguda. Em certas condições, entretanto, a resposta inflamatória apresenta falhas em sua regulação, resultado de condições anormais, levando a perda de função do órgão ou tecido afetado, e ao desenvolvimento de diversas doenças, sendo classificada como inflamação crônica. Doenças inflamatórias crônicas afligem milhões de pessoas ao redor do globo que são obrigadas a aderir a tratamentos com muitos efeitos colaterais. Esse contexto torna indispensável o desenvolvimento de medicamentos anti-inflamatórios eficazes, econômicos e mais seguros do que os atuais, de forma a melhorar a qualidade de vida desses pacientes. Diante desse enorme desafio, as plantas medicinais ganham destaque como possíveis fontes de novas moléculas bioativas. $\mathrm{O}$ Cerrado brasileiro apresenta diversas espécies com imenso potencial, entre elas aquelas do gênero Pouteria, que tem sido usado como plantas medicinais dentro da medicina popular e recentemente tornaram-se alvos de diversos estudos. O objetivo do presente trabalho foi avaliar a atividade anti-inflamatória de extratos de folha de Pouteria torta e Pouteria ramiflora em macrófagos da linhagem J774A. 1 ativados com $1 \mu \mathrm{g} / \mathrm{mL}$ de LPS. A viabilidade celular e citotoxidade foram avaliadas utilizando os métodos WST-8 e vermelho neutro, e a modulação de genes pró-inflamatórios empregando a técnica de quantificação relativa através de qPCR. A resposta inflamatória foi medida por meio da dosagem do mediador inflamatório óxido nítrico (NO) através de espectrofotometria pelo método de Griess. Os resultados obtidos após o estudo indicam atividades biológicas nas concentrações de $0,078,0,039$ e $0,020 \mathrm{mg} / \mathrm{mL}$ em todos os extratos testados. Nestas concentrações empregadas no tratamento, as células J774A.1 estimuladas com LPS não apresentam perda de viabilidade celular, reduziram a produção de NO e também a expressão do número de transcritos de genes marcadores de inflamação $N F-\kappa B, I L-6$, TNF- $\alpha, C O X-2$ e iNOS. Os resultados sugerem que os extratos de Pouteria torta e Pouteria ramiflora apresentam substâncias primárias e secundárias com atividade antiinflamatória demonstrada neste estudo, e por tratar-se de um fitocomplexo há que se considerar essa atividade biológica como de grande potencial terapêutico como antiinflamatórios para estes extratos das plantas estudadas.

Palavras-chaves: Anti-inflamatório, Pouteria spp., Cerrado brasileiro, J774A.1 


\begin{abstract}
The inflammatory process is the most ancient immunologic component to be developed in our group evolution. It is considered a complex mechanism, consisting of several cellular types and highly regulated, serving as a primary line of defense in the immune response against various stimuli. Normally this kind of response is beneficial for the organism, self-regulated, which reestablishes homeostasis in a short time and is classified as an acute inflammation. However, in certain conditions, the inflammatory response presents deficiencies in its regulation, resulting from abnormal conditions, leading to loss of function of the affected organ or tissue, and the development of several diseases classified as chronic inflammation. Chronic inflammation diseases afflict millions of people around the globe, people who are forced to adhere to treatments with many side effects. In light of such facts, the pursuit of new, more efficient, economic and less harmful anti-inflammatory drugs is indispensable to improve the quality of life of these patients. Faced with such enormous challenge, medicinal plants have a primary role in this scenario as a possible source of bioactive molecules. The Brazilian Cerrado has several species with an immense potential, including those of the genre Pouteria, which have been used in popular medicine and recently have been investigated in some studies. The goal of this research was to evaluate anti-inflammatory and anti-oxidant activities in leaf extracts of Pouteria torta and Pouteria ramiflora activated with $1 \mu \mathrm{g} / \mathrm{mL}$ of LPS. Cell viability and cytotoxicity were evaluated using the WST- 8 and neutral red methods, the modulation of pro-inflammatory genes using the technique of relative quantification through qPCR. The inflammatory response was measured by the dosage of the inflammatory mediator nitric oxide (NO) through spectrophotometry and the Griess method. The results obtained after the study indicate biological activities at concentrations of $0.078,0.039$ and $0.020 \mathrm{mg} / \mathrm{mL}$ in all tested extracts. At these concentrations used in the treatment, LPS-stimulated J774A.1 cells showed no loss of cell viability, reduced NO production and also expression of the number of transcripts of marker genes of inflammation NF- $\kappa \mathrm{B}, \mathrm{IL}-6, \mathrm{TNF}-\alpha, \mathrm{COX}-2$ and iNOS. Considering the studied of these extracts, the results suggest that extracts of Pouteria torta and Pouteria ramiflora present primary and secondary substances with anti-inflammatory activity demonstrated, and because it is phytocomplex it is necessary to consider this biological activity as having great therapeutic potential as anti-inflammatory.
\end{abstract}

Key Word: Anti-inflammatory, Pouteria spp., Brazilian Cerrado, J774A.1 


\section{LISTA DE FIGURAS}

Figura 1 - Mecanismo de migração de leucócitos por meio de vasos sanguíneos em direção ao local de inflamação. Inicialmente os leucócitos rolam, são ativados e então se ligam ao endotélio, penetrando em direção a membrana basal. Eles então seguem em direção as quimiocinas liberadas na fonte da lesão

Figura 2 - Mecanismos associados à inflamação, incluindo sua resolução, perda de função por fibrose e desenvolvimento de inflamação crônica

Figura 3 - Delineamento Experimental desenvolvido durante o trabalho

Figura 4 - Produção de óxido nítrico no sobrenadante de células J774A.1 em diversas concentrações celulares e em tempos de 6, 24 e 48 horas.

Figura 5 - Análise da interação química entre os extratos de Pouteria torta (PT Et) e Pouteria ramiflora (PR Aq e PR Et) nas diferentes concentrações utilizadas e o reagente de WST-8 (Cell Counting kit-8).

Figura 6 - Efeitos dos extratos de Pouteria torta (PT Et) e Pouteria ramiflora (PR Aq e PR Et) sobre a viabilidade celular de células J774A.1 nas concentrações onde não existe interação química com o reagente WST-8 40

Figura 7 - Interação química entre os extratos de Pouteria torta (PT Et) e Pouteria ramiflora (PR Aq e PR Et) nas diferentes concentrações utilizadas e o reagente vermelho neutro

Figura 8 - Efeitos dos extratos de Pouteria torta (PT Et) e Pouteria ramiflora (PR Aq e PR Et) sobre a viabilidade celular das células J774A.1 com base no método de incorporação do vermelho neutro

Figura 9 - Expressão gênica de células J774A.1 48 horas após tratamento com extratos de Pouteria torta (PT Et) nas concentrações de 0,020, 0,039 e 0,078 mg/mL

Figura 10 - Expressão gênica de células J774A.1 48 horas após tratamento com extratos de Pouteria ramiflora (PT Aq) nas concentrações de 0,020, 0,039 e 0,078 mg/mL..... 46 
Figura 11 - Expressão gênica de células J774A.1 48 horas após tratamento com extratos de Pouteria ramiflora (PT Et) nas concentrações de $0,020,0,039$ e $0,078 \mathrm{mg} / \mathrm{mL}$ Análise estatística ANOVA de duas vias com pós-teste de Bonferroni de múltipla comparação, os resultados de Quantificação Relativa em comparação com o LPS revelaram **** $p<0.001$

Figura 12 - Nível de produção de óxido nítrico no sobrenadante de células da linhagem J774A.1 após 48 horas de tratamento com os extratos PT Et, PR Aq e PR Et nas concentrações padronizadas $(0,078,0,039,0,020 \mathrm{mg} / \mathrm{mL})$ e estimulados com $1 \mu \mathrm{g} / \mathrm{mL}$ de LPS. 


\section{LISTA DE TABELAS}

Tabela 1 - Espécies de plantas utilizadas no estudo

Tabela 2 - Informações sobre os extratos utilizados

Tabela 3 - Genes analisados no estudo 30

Tabela 4 - Sequência dos Primers dos genes utilizados no estudo em reações de qPCR

Tabela 5 - Threshold, quantidade de primers e de cDNA e condições de termociclagem padronizadas para cada um dos primeris a partir dos ensaios de curva padrão e otimização para amplificação por qPCR

Tabela 6 - Grupos Controle utilizados no estudo 35 


\section{LISTA DE ABREVIATURAS E SIGLAS}

$\begin{array}{ll}\text { AINES } & \text { Anti-Inflamatórios Não Esteroidais } \\ \text { ATCC } & \text { American Type Culture Collection } \\ \text { BCRJ } & \text { Banco de Células Rio de Janeiro } \\ \text { cDNA } & \text { DNA Complementar } \\ \text { COX-1 } & \text { Ciclo-Oxigenase 1 } \\ \text { COX-2 } & \text { Ciclo-Oxigenase 2 } \\ \text { Ct } & \text { Threshold Cycle } \\ \text { D.O. } & \text { Densidade Óptica }\end{array}$

DMEM Dulbecco Modified Eagle Medium

DMSO Dimetilsulfóxido

DNA Ácido Desoxirribonucleico

GAPDH Glyceraldehyde 3-Phosphate Dehydrogenase

HEPES Ácido 2,4-hidroetilpiperazina-1-etanosulfônico

HIF-1 $\alpha \quad$ Fator Indutor de Hipóxia

IDT Integrated DNA Technologies

IL-6 Interleucina 6,

iNOS Óxido Nítrico Sintetase Induzida

LOX Lipoxigenases

LPS Lipopolissacarídeo

MTT Methyl-Thiazolyl-Tetrozalium

NCE Novas Entidades Químicas

NEED Dicloridrato de N-1-naftiletilenodeamida

NFkB Fator Nuclear kappa B

NO Óxido Nítrico

NOS Óxido Nítrico Sintetase

OMS Organização Mundial de Saúde

PAMP Padrões Moleculares Associados a Patógenos 
PBS Solução Tampão Fosfato Salino

PRR Receptores de Reconhecedores de Padrão

qPCR Reação de Polimerase em Cadeia em Tempo Real

RNA Ácido Ribonucleico

ROS Espécies Reativas de Oxigênio

SFB Soro Fetal Bovino

TNF- $\alpha \quad$ Fator de Necrose Tumoral- $\alpha$

USA Estados Unidos da América

WST-8 Cell Counting Kit-8 


\section{SUMÁRIO}

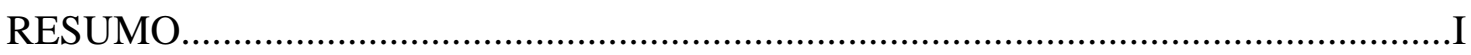

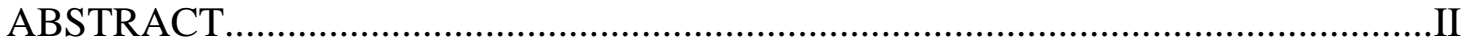

LISTA DE FIGURAS...........................................................................................

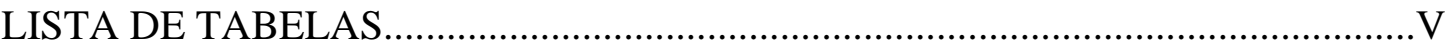

LISTA DE ABREVIATURAS E SIGLAS.............................................................

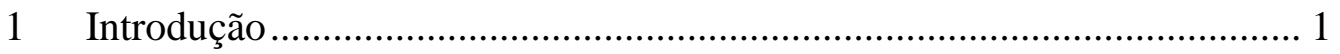

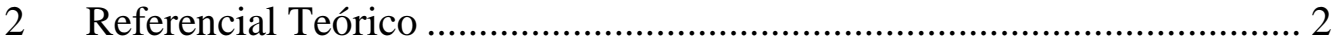

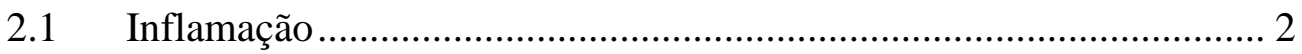

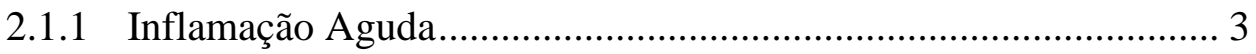

2.1.2 Inflamação Crônica.................................................................. 6

2.2 Mediadores Inflamatórios ….................................................... 9

2.2.1 Óxido Nítrico ...................................................................... 9

2.3 Tratamentos atuais e suas limitações ............................................. 10

2.4 Substâncias derivadas de plantas como alternativas para desenvolvimento de novos fármacos ..................................................... 12

2.5 Plantas medicinais do cerrado brasileiro e sua atividade .................. 14

2.5.1 O gênero Pouteria (Sapotaceae Juss.) ......................................... 15

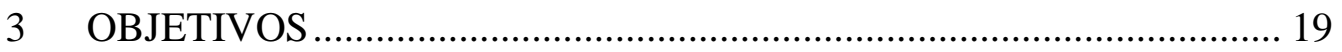

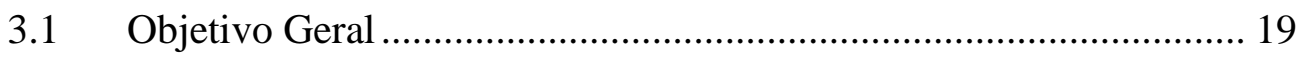

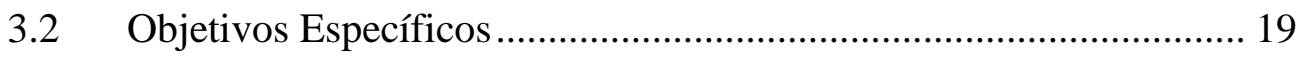

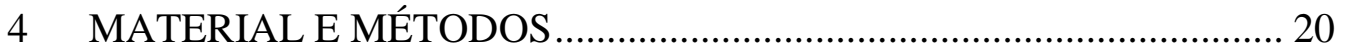

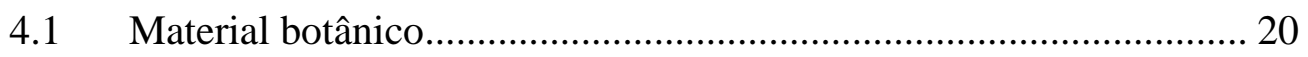

4.2 Extração botânica ........................................................................... 20

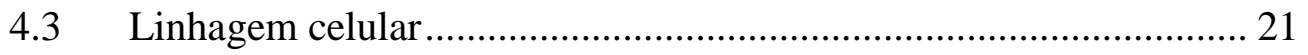

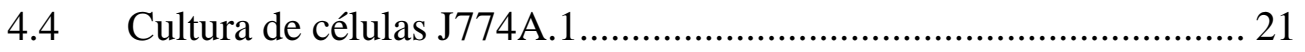

4.5 Modelo inflamatório da linhagem celular J774A.1 empregado no estudo 22

4.6 Delineamento experimental........................................................ 23 
4.7 Avaliação de viabilidade celular após interação com os extratos de plantas 24

4.7.1 Ensaio de WST-8 24

4.7.2 Ensaio de Vermelho Neutro....................................................... 25

4.8 Dosagem de Óxido Nítrico (NO) .................................................. 26

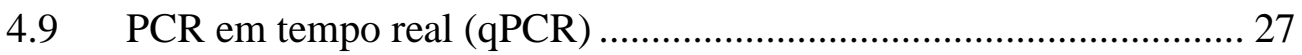

4.9.1 Extração e Purificação do RNA..................................................... 27

4.9.2 Análise do RNA extraído......................................................... 28

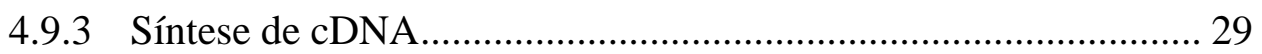

4.9.4 Definição dos genes de Interesse ............................................... 29

4.9.5 Padronização das concentrações dos Primers .............................. 30

4.9.6 Titulação dos Primers .................................................................. 32

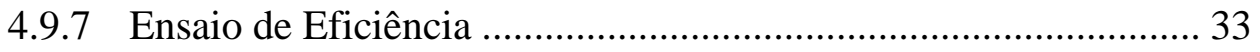

4.9.8 Reação em Cadeia da Polimerase quantitativa em Tempo Real (qPCR) 34

4.9.9 Expressão gênica .............................................................. 34

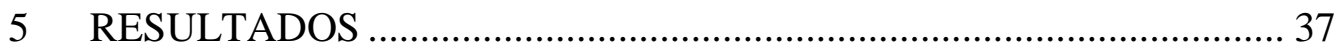

5.1 Avaliação de diferentes concentrações celulares numa cinética de ativação da linhagem celular J774A.1 com $1 \mu \mathrm{g} / \mathrm{mL}$ de LPS ........................ 37

5.2 Ensaios para avaliação da viabilidade celular após interação com os

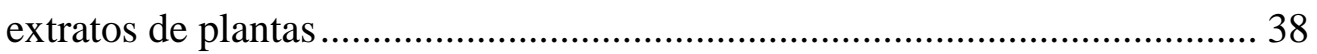

5.2.1 Ensaio utilizando como reagente WST-8 ................................. 38

5.2.2 Ensaio utilizando como reagente Vermelho Neutro .................... 40

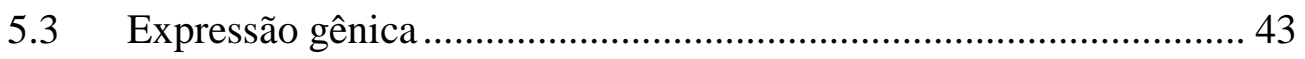

5.3.1 Quantificação relativa dos transcritos dos genes NFkb, Tnf- $\alpha$, IL-6, iNOS e COX-2 após tratamento com extrato etanólico de Pouteria torta (PT Et) $\quad 43$

5.3.2 Quantificação relativa dos transcritos dos genes NFkb, Tnfa, IL-6, iNOS e Cox-2 após tratamento com extrato aquoso de Pouteria ramiflora (PR Aq) 45 
5.3.3 Quantificação relativa dos transcritos dos genes NFkb, Tnfa, IL-6, iNOS e Cox-2 após tratamento com extrato etanólico de Pouteria ramiflora (PR Et) 47

5.4 Dosagem de Óxido Nítrico........................................................... 49

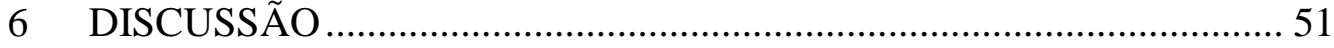

7 CONCLUSÃO

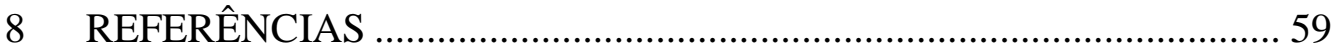




\section{INTRODUÇÃO}

Uma grande parcela da população global é vítima de doenças crônicas. No Brasil o Ministério da Saúde estima que 72 \% das mortes estão associadas com doenças crônicas não transmissíveis. Muitas vezes essas doenças têm seus sintomas derivados de um processo inflamatório crônico. Atualmente o tratamento de doenças inflamatórias é realizado principalmente através de Anti-Inflamatórios Não Esteroidais (AINES), medicamentos que levam a efeitos colaterais caso utilizados de forma constante ou durante um longo período (BRASIL, 2014; NGUTA et al., 2016; SOLEIMANPOUR et al., 2016).

Nesse contexto o desenvolvimento de fármacos com atividade anti-inflamatória com efeitos colaterais menos proeminentes é fundamental para garantir qualidade de vida para uma parcela significativa da população. Plantas medicinais são tidas como importantes fontes de moléculas bioativas, e recentes estudos com plantas do cerrado tem demonstrado potencial como anti-inflamatórios em determinadas famílias. Entre as espécies estudadas o gênero Pouteria revela grande potencial, o que justifica novos estudos investigando as propriedades dessas plantas sob modelos inflamatórios (NEWMAN; CRAGG, 2016; OKSMANCALDENTEY; INZÉ, 2004; POLITO et al., 2016; SILVA; SIMEONI; SILVEIRA, 2009).

O presente estudo tem como objetivo avaliar o potencial anti-inflamatório de extratos de plantas das espécies Pouteria torta e Pouteria ramiflora em modelo celular in vitro utilizando células da linhagem J774A.1, células de murinos comumente utilizadas em ensaios inflamatórios. Tais células serão estimuladas com lipopolissacarídeo obtido de Escherichia coli e posteriomente tratadas com os extratos de forma a possibilitar a avaliação de marcadores inflamatórios e sua modulação após o tratamento (ALLEN et al., 2005; D’AGOSTINO et al., 2001a; TEOTÔNIO, 2015; WONG et al., 2016).

O presente estudo é uma pesquisa experimental com o objetivo de promover modulação de diversos mediadores inflamatórios na presença dos extratos, mais especificamente genes relacionados com vias metabólicas pró-inflamatórias e a produção de um dos derivados dessa via, o óxido nítrico. Todos os genes avaliados atuam em vias que sofrem retroalimentação positiva uma vez estabelecidas as condições inflamatórias e estão relacionados a condições inflamatórias crônicas (COLEMAN, 2001; DRAGHICIU et al., 2015; MÓCSAI; WALZOG; LOWELL, 2015). 


\section{REFERENCIAL TEÓRICO}

\subsection{Inflamação}

Durante o processo evolutivo o sistema imunológico sofreu inúmeras alterações, sendo hoje um sistema complexo composto de diversos fatores, entre ele componentes puramente físicos como barreiras epiteliais e outros ainda mais elaborados, como os fatores humorais e tipos celulares especializados na defesa do organismo contra agentes patogênicos. Classicamente o sistema imunológico é dividido em duas frentes, a resposta inata, que envolve reações inespecíficas contra patógenos, e a resposta adaptativa, que é extremamente especifica a cada patógeno (LIBBY; RIDKER; HANSSON, 2009; NETEA; QUINTIN; VAN DER MEER, 2011).

A resposta inata é evidenciada como a primeira forma de defesa dentre os organismos dotados de sistema imunológico, sendo presente até mesmo em organismos invertebrados e verificado em plantas. Um dos seus principais mecanismos é a chamada inflamação, que também é seu elemento mais antigo (KUMAR V, ABBAS A. K., 2013).

Inflamação é uma palavra derivada do latim, inflammare no original, o que em uma tradução aproximada significa "em chamas", é um conceito que foi construído ao longo dos séculos de estudos, assim como todos os demais conceitos científicos modernos. O primeiro a relatar o processo inflamatório foi o escritor egípcio Aulus Cornelius Celsus, no século 1 do calendário gregoriano, que descreveu a inflamação como um processo ligado a quatro sinais cardinais: vermelhidão, edema, dor e rubor. Tal definição limita o conceito de inflamação a apenas seus sintomas clínicos, deixando de lado a fisiopatologia (SCOTT, 2004).

Esse conceito foi então expandido por Galen cerca de dois séculos após os estudos de Celsus sob um ponto de vista humoral do processo inflamatório, propondo que a inflamação seria uma resposta benéfica à injúria e não outra patologia sobreposta. Essa visão persistiu até o século XIX quando o médico alemão Rudolf Virchow propôs a adição de um quinto sinal cardinal ao processo inflamatório, a perda de função, conectando a inflamação a processos patológicos (PERKINS, 2010).

Com base em observações experimentais (ingestão de espinhos de rosas por amebócitos, de larvas de estrela do mar e ingestão de bactérias por glóbulos brancos de mamíferos) o biólogo russo Elie Metchnikoff, em 1882, descreveu o mecanismo fagocítico presente no processo inflamatório, mostrando que células específicas eram recrutadas para a 
região onde há uma lesão ou um agente inflamatório, com a finalidade de englobar o invasor (HEIFETS, 1982; SCOTT, 2004).

Os estudos de Metchnikoff podem ser considerados o nascimento da imunologia e o levaram ao Nobel de Medicina ou Fisiologia em 1908 em conjunto com Paul Ehrlich, que por sua vez estudou as bases humorais da resposta imune. Em conjunto com o mecanismo celular descrito por Metchnikoff, mecanismos humorais foram descritos por Thomas Lewis, que descobriu a existência de moléculas produzidas no sítio de inflamação capazes de mediar alterações vasculares, como a histamina, o que levou a conclusões essenciais para identificação de mediadores inflamatórios e o uso de medicamentos na medicina clínica (PERKINS, 2010).

A resposta inflamatória é atualmente conceituada como um mecanismo biológico complexo e normalmente autorregulado que atua na defesa do organismo frente a diversos estímulos, sejam de ordem física, química ou patológica, e que tem como objetivo restabelecer a homeostase (CHOI et al., 2014; CHOVATIYA; MEDZHITOV, 2014; YING et al., 2013).

Como evidenciado anteriormente, normalmente a resposta inflamatória é benéfica ao hospedeiro, havendo produção de diversas substâncias que inibem o processo inflamatório após um certo tempo de estímulo, restabelecendo a função do tecido ou órgão afetado. Entretanto, existem diversas condições fisiológicas onde o processo inflamatório não é inibido ou então recebe estímulos para se estabelecer continuamente, havendo nesses casos cronicidade da inflamação, algo que pode ser extremamente patológico ao organismo, levando até mesmo a atrofia de tecidos e/ou órgãos ou mesmo óbito do indivíduo acometido (HANADA; YOSHIMURA, 2002; LAWRENCE; WILLOUGHBY; GILROY, 2002).

\subsubsection{Inflamação Aguda}

A inflamação aguda é um processo de alta complexidade, que envolve uma grande gama de tipos celulares e produção de diversos mediadores químicos, entretanto podemos dividi-la em quatro componentes principais: indutores inflamatórios, mecanismos de reconhecimento, mediadores e tecido alvo. Esses elementos normalmente funcionam em harmonia para possibilita uma resposta que seja imediata ao sinal indutor, autolimitada pela produção de mediadores e benéfica a microcirculação do tecido alvo. Tudo em função do reconhecimento dos sinais inflamatórios, como toxinas ou outros elementos estranhos ao organismo (OKIN; MEDZHITOV, 2012). 
A resposta inflamatória aguda é altamente benéfica ao organismo, levando a restauração do tecido alvo em um curto intervalo de tempo. Essa resposta normalmente é mediada pela imunidade inata, mas pode estar associada com a resposta adaptativa em alguns casos. Como abordado anteriormente, essas duas respostas em conjunto formam o sistema imunitário do hospedeiro (LAWRENCE; WILLOUGHBY; GILROY, 2002).

As defesas inatas do organismo podem ser acionados por diversos estímulos, entre ele estão inclusos infecções microbianas (bacterianas, virais, fúngicas, entre outras), que ativam Receptores de Reconhecedores de Padrão (PRRs) em células imunes inatas pela presença de elementos inflamatórios conhecidos como Padrões Moleculares Associados a Patógenos (PAMPs), por exemplo, o lipopolissacarídeo, reações autoimunes ou de hipersensibilidade a fatores endógenos, levando a destruição de tecidos do próprio individuo; necrose tecidual decorrida de diversos fatores, tais como lesões em tecidos estéreis; hipóxia, normalmente mediada pelo Fator Indutor de Hipóxia $(\mathrm{HIF}-1 \alpha)$, que é produzido por células privadas de oxigênio que possam ativar genes envolvidos na via inflamatória; e, por fim, por estímulos exógenos, normalmente relacionados a corpos estranhos ou suturas cirúrgicas, que possibilitam lesões teciduais traumática e transporte de micro-organismos (KUMAR V, ABBAS A. K., 2013; VALLIÈRES; DU SOUICH, 2010).

Como dito anteriormente, a inflamação é um conjunto coordenado de diversos eventos altamente complexos e cuidadosamente regulados para que ocorra de forma benéfica ao organismo. Tais eventos compreendem mudanças fisiológicas, celulares e moleculares no tecido onde o processo inflamatório se instalará, que é iniciado pela produção de mediadores solúveis tais como quimiocinas, citocinas, eicosanoides como prostaglandinas, radicais livres, aminas vasodilatadoras, etc. Essas substâncias são produzidas por células que estão presentes nos tecidos, entre elas macrófagos, células dentríticas, células endoteliais, entre diversas outras (BUCKLEY et al., 2015; LAWRENCE; WILLOUGHBY; GILROY, 2002).

Para ser efetiva, a resposta inflamatória precisa ser formada rapidamente. Por tal razão, a resposta vascular, que será responsável pelo recrutamento celular, é estabelecida segundos após a formação de lesão tecidual, sendo mediada principalmente pelo tecido endotelial, que é responsável por induzir a vasodilatação e aumento de permeabilidade dos capilares locais. Esse aumento de vascularização, ou hiperemia, resulta em um dos sinais cardinais da inflamação, o eritema, que permite a entrada de líquido extracelular no tecido alvo, gerando o edema local, onde fibroblastos e células epiteliais são ativadas (BUCKLEY et al., 2015).

Esse aumento de fluxo sanguíneo e permeabilidade vascular local é responsável pelo recrutamento de vários tipos celulares, entre eles leucócitos polimorfonucleares, que liberaram 
mediadores tóxicos, levando a perda de função do órgão afetado, outro sinal cardinal do processo inflamatório. Em conjunto com as manifestações clínicas citadas anteriormente, essas respostas fisiológicas levarão às demais características cardinais da inflamação: calor, dor, rubor e edema (BUCKLEY et al., 2015; LAWRENCE; WILLOUGHBY; GILROY, 2002; TAKEUCHI; AKIRA, 2010). Dentre os leucócitos polimorfonucleares encontram-se os neutrófilos, células que recrutam monócitos, que então se diferenciarão em macrófagos, células fundamentais para apresentação de antígenos (LAWRENCE; WILLOUGHBY; GILROY, 2002).

Neutrófilos estão entre as primeiras células a serem recrutadas para o sítio inflamatório, em conjunto com monócitos, e são o tipo celular mais abundante em processos inflamatórios agudos, embora também sejam importantes em processos crônicos. Por seu papel fundamental em conter e posteriormente dispor do agente causador da inflamação os neutrófilos podem ser considerados a primeira linha de defesa do organismo (WANG, 2016).

Os eventos de migração e ativação de neutrófilos para a região lesionada é um evento amplamente descrito na literatura, sendo composto de seis etapas que ocorrem em sequência: quimiotaxia (migração do neutrófilo para o local desejado provocado pela presença de mediadores quimiotáticos produzidos pelas células locais); marginalização (fenômeno resultante da dilatação de vasos na região afetada, o que leva a diminuição do fluxo sanguíneo no local da lesão e segregação dos neutrófilos próximos a parede do vaso pela ação de eritrócitos e fibrogênios), rolamento na superfície endotelial (que é mediada por ação de diversas moléculas da família das selectinas e adesão por meio de integrinas), diapedese (passagem dos neutrófilos entre as células endoteliais das vênulas para então ganhar o tecido intersticial), e, por fim, a fagocitose (ingestão e posterior destruição dos patógenos após opsonização desses) (Figura 1) (KUMAR V, ABBAS A. K., 2013; RIBEIRO, D.; FREITAS, M.; LIMA, J.L.F.C.; FERNANDES, 2015). 


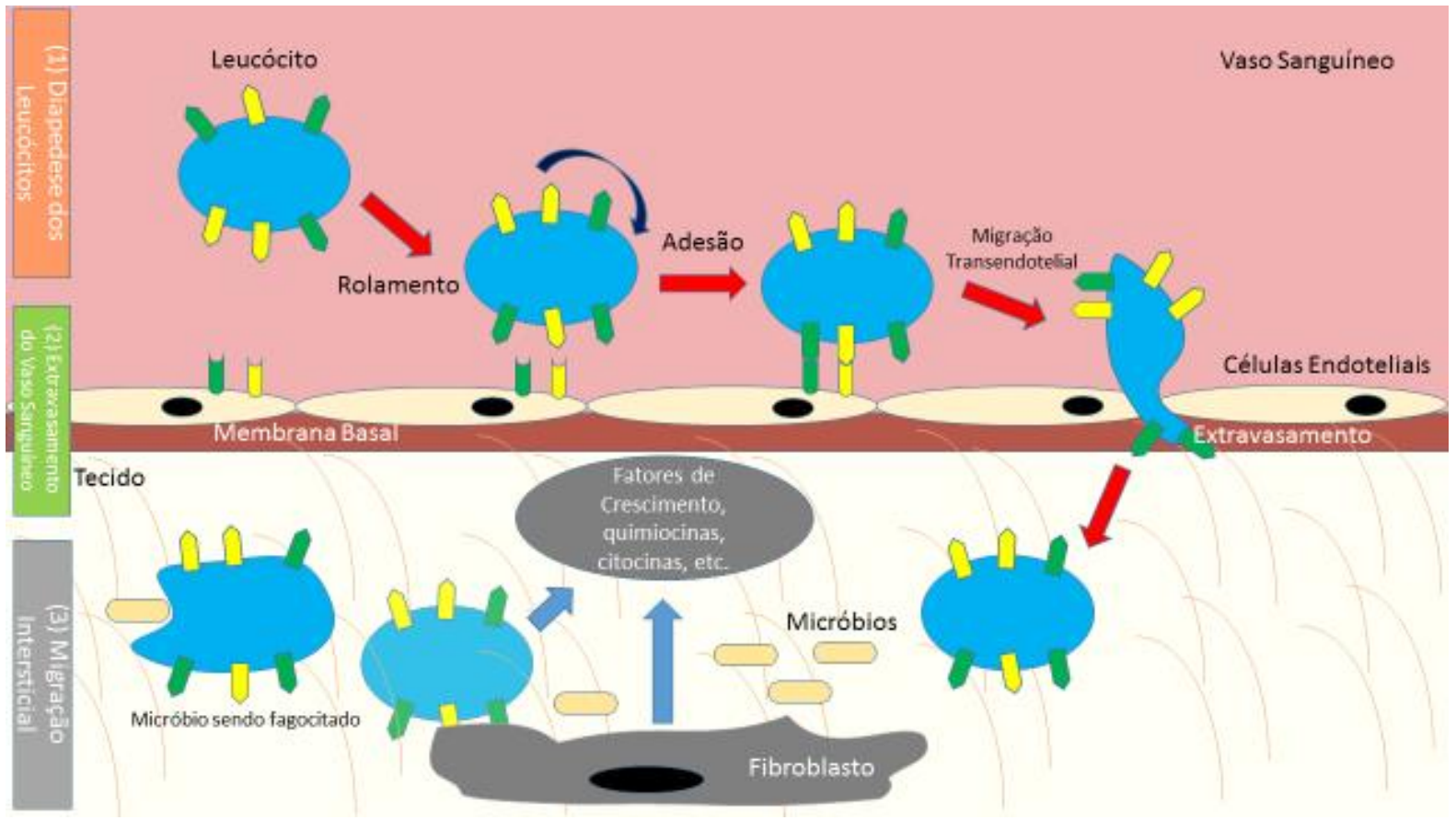

Figura 1 - Mecanismo de migração de leucócitos por meio de vasos sanguíneos em direção ao local de inflamação. Inicialmente os leucócitos rolam, são ativados e então se ligam ao endotélio, penetrando em direção a membrana basal. Eles então seguem em direção as quimiocinas liberadas na fonte da lesão

\subsubsection{Inflamação Crônica}

Embora a resposta imune seja normalmente autorregulada e restrita, sendo dessa forma benéfica e importante para a recuperação da homeostase, existem casos onde a inflamação pode desenvolver cronicidade quando há falhas no processo de remoção de antígenos ou na eliminação de células inflamatórias apoptóticas, podendo até mesmo levar a fibrose tecidual (Figura 2), gerando perda funcional no órgão ou tecido afetado (DE PAULA ROGERIO et al., 2015; KUMAR V, ABBAS A. K., 2013). 


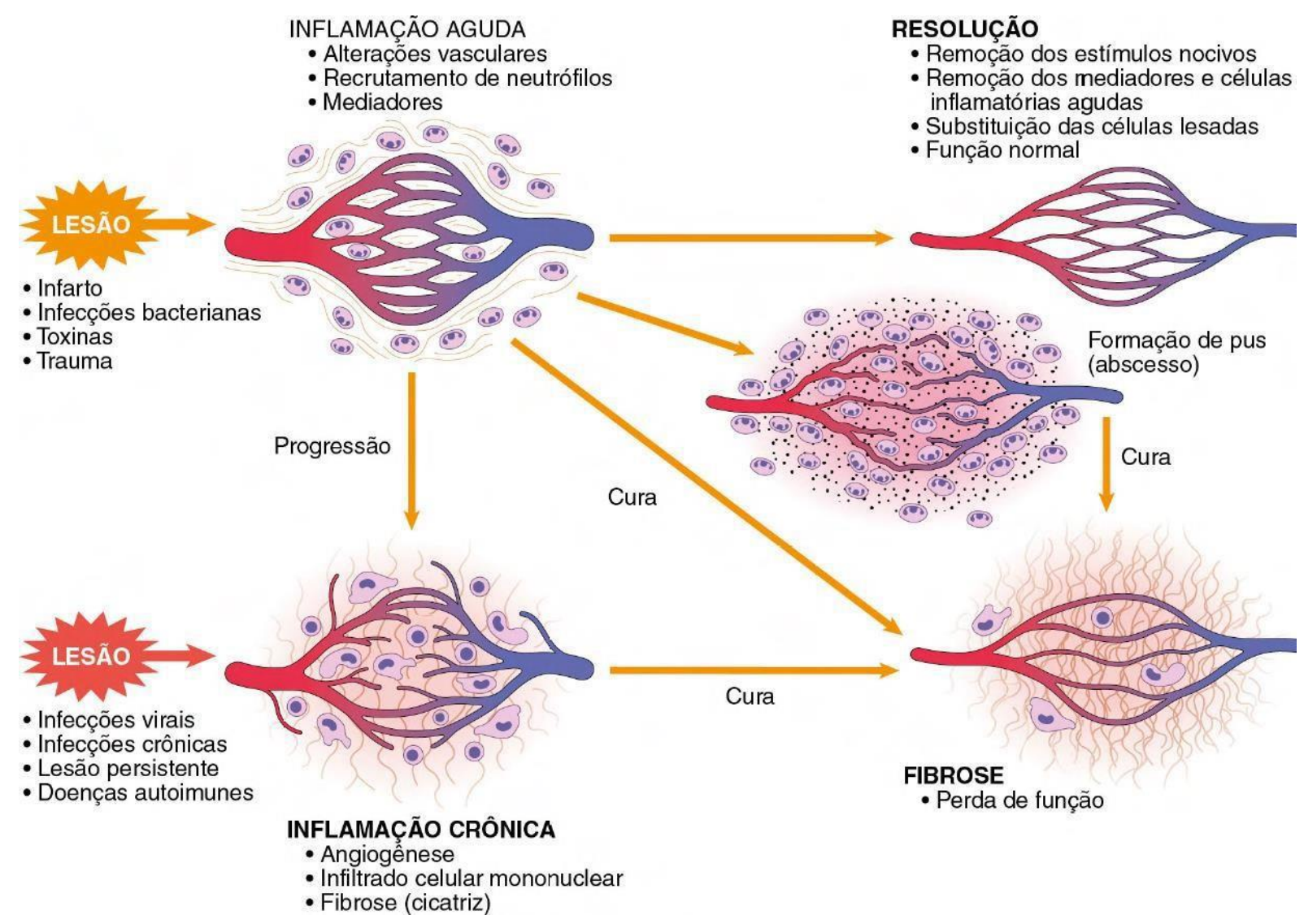

Figura 2 - Mecanismos associados à inflamação, incluindo sua resolução, perda de função por fibrose e desenvolvimento de inflamação crônica

Fonte: Adaptado de KUMAR V, ABBAS A. K., 2013

Como evidenciado, o processo inflamatório crônico ocorre posteriormente a uma resposta aguda que por alguma razão não foi resolvida, seja por falha na autorregulação ou permanência da lesão que a causou inicialmente. Macrófagos e linfócitos normalmente tem um papel importante nesses processos, sendo recrutados para o local. Muitas vezes essa resposta prolongada pode levar a modificações no local afetado, podendo ocorrer um processo de angiogênese (formação de novos vasos sanguíneos) ou fibrose (substituição do tecido local por um tecido conjuntivo denso). A resposta que leva a formação de um processo inflamatório crônico pode vir do sistema adaptativo (produção de citocinas por linfócitos T, induzindo inflamação), mesmo que normalmente esteja relacionado com o sistema imunitário inato (LIBBY; RIDKER; HANSSON, 2009; LUNDVIG; IMMENSCHUH; WAGENER, 2012).

Diferente da inflamação aguda a resposta crônica não possui autolimitação, contribuindo dessa forma para a patogênese de diversas enfermidades, sendo caracterizada pelo acúmulo de células pró-inflamatórias no local da lesão ou acúmulo de antígeno, levando muitas vezes a perda da função do órgão ou tecido afetado. Diversos exemplos de patologias descritas 
na literatura estão relacionados com processos inflamatórios crônicos, como artrite reumatoide, asma, aterosclerose, câncer e doença celíaca, para citar algumas (LAWRENCE; WILLOUGHBY; GILROY, 2002; LIBBY; RIDKER; HANSSON, 2009; MERESSE; MALAMUT; CERF-BENSUSSAN, 2012; PYEE et al., 2014).

A causa da falha no processo de autorregulação pode ser atribuída a diversos fatores, dentre eles infecções por micro-organismos resistentes ou de difícil eliminação, como em doenças como Chagas, ou falhas nos processos de auto reconhecimento do sistema imune, levando a doenças autoimunes e possivelmente a outros processos ainda não tão bem elucidados, tal como a miopia. Em casos autoimunes o corpo reage de forma inapropriada a estímulos que podem ser de origem endógenas (como no caso de doenças autoimunes como a diabetes, onde o organismo destrói as células-beta pancreáticas) ou exógenos (por exemplo inalação de sílica por um longo período de tempo) (DE MELO et al., 2012; KUMAR V, ABBAS A. K., 2013; NUNEMAKER, 2016; PERKINS, 2010).

Em conjunto com esses diversos fatores, ainda existe a produção continua de mediadores pró-inflamatórios diversos pelas células da lâmina própria do local afetado, além do continuo recrutamento de células, como monócitos, para o sitio de inflamação, fatores genéticos e influência ambiental conduzem a danos no tecido. Caso o tecido lesionado e os macrófagos ativados não sejam eliminados pela resposta imune do hospedeiro a resposta inflamatória pode ser agravada, ativando a resposta imune adaptativa e tornando o processo crônico (FICHTNER-FEIGL et al., 2008; HASSOUN; REDDY, 2010; MA et al., 2004).

Devido ao alto recrutamento celular e a produção de citocinas pró-inflamatórias, existe uma renovação celular constante em processos inflamatórios crônicos, havendo aumento na taxa de proliferação celular, o que aumenta a probabilidade de erros durante o processo de replicação, possivelmente levando a mutações e até mesmo a surgimento de carcinomas. Os produtos gerados pelo metabolismo de leucócitos e outros tipos celulares (leucotrienos, espécies ativas de oxigênio e nitrogênio, entre outros) acabam provocando danos no DNA, que podem levar as referidas mutações (IOANNIDOU; GOULIELMAKI; GARINIS, 2016; RUDDLE, 2016; WU et al., 2016).

Entre os produtos liberados pelas células inflamatórias encontram-se as prostaglandinas, produtos da ação da enzima ciclo-oxigenase 2 (COX-2), que intensificam o processo inflamatório e podem levar ao desenvolvimento de neoplasias por diversas vias, além da enzima em questão estar associada com outras patologias (alergias, aterosclerose, asma, entre outras). Com esses elementos em mente é evidente que a resolução prematura desse 
processo inflamatório persistente é chave na resolução de várias patologias, se não pelo menos como uma forma de limitar os sintomas (HEADLAND; NORLING, 2015).

\subsection{Mediadores Inflamatórios}

A inflamação aguda depende da liberação de diversos mediadores químicos que iram intermediar o recrutamento de células para o local da inflamação, sendo os neutrófilos os primeiros a chegarem no local. Tais mediadores atuam induzindo vasodilatação no local e a quimiotaxia dos neutrófilos que estão circulando livremente na corrente sanguínea. (KENNETH L. ROCK, EICKE LATZ, FERNANDO ONTIVEROS, 2010; MÓCSAI; WALZOG; LOWELL, 2015).

A resolução da inflamação aguda é o resultado ideal dessa resposta do organismo, revertendo a homeostase do tecido ou órgão alvo do processo inflamatório. Este é um processo bioquímico altamente intenso, havendo a participação de diversos mediadores, entre eles resolvinas, protectinas e maresinas. Tais mediadores são essenciais para a resolução do processo inflamatório, sendo responsáveis por ativar vias que sinalizam o fim da fase aguda fisiológica inflamatória (LEVY et al., 2001; SERHAN et al., 2014).

Macrófagos tem um papel fundamental na mediação fisiológica e molecular do processo inflamatório por meio da produção de citocinas, enzimas inflamatórias e outros mediadores pró-inflamatórios em geral como prostaglandinas e radicais livres, sendo o mais relevante dentre eles o óxido nítrico (LASKIN,DEBRA L. AND PENDINO, 1995; PARK et al., 2011).

\subsection{1 Óxido Nítrico}

O Óxido Nítrico (NO) é um mensageiro molecular de curto tempo de meia-vida que desempenha um grande número de funções dentro do organismo, atuando na regulação de diversos mecanismos fisiológicos dentro do sistema circulatório, neural e imune. Essa molécula pode atuar em papeis contraditórios dentro do organismo, podendo por exemplo, ser um indutor de apoptose ou inibidor, dependendo da produção. Dentro do sistema neural essa molécula atua de forma semelhante a um neurotransmissor, no sistema vascular ele atua como um fator de regulação do tônus vascular, além de inibir agregação plaquetária. No sistema imune ele atua como um fator tóxico em relação a organismos infectantes e um imuno 
regulador, estando envolvido com diversas vias metabólicas no sistema inato (AKTAN, 2004; COLEMAN, 2001; D’AGOSTINO et al., 2001b).

O NO é um mediador produzido por diversas células no organismo, entre elas células endoteliais, fibrócitos e macrófagos, difunde-se livremente nos tecidos, sendo capaz de atravessar membranas plasmáticas sem resistência. Quando em altas concentrações ao ser produzido pela forma induzível da Óxido Nítrico Sintetase (NOS) e sob condições aeróbicas o NO é rapidamente oxidado formando espécies reativas de oxigênio (ROS). Como são altamente instáveis e oxidativas, as ROS são rapidamente nitrosadas ou hidrolisadas de forma a serem inativadas (COLEMAN, 2001).

As NOS são enzimas que catalisam a conversão de L-arginina e oxigênio molecular em L-citrulina e NO. Existem 3 isoformas dessas enzimas, sendo cada uma relacionada com um conjunto característico de expressões. A nomenclatura de cada uma dessas isoformas da enzima é derivada do padrão de expressão ao qual a enzima está relacionada. A primeira isoforma, NOS 1, também pode ser denominada nNOS por ser expressa em neurônios e outras células cerebrais. A NOS 2 também é conhecida como iNOS pelo fato de sua produção ser induzida mediante a ativação celular. A NO3 é referida como eNOS por sua produção estar associada com células endoteliais (AMANO; NODA, 1995; MATTILA; THOMAS, 2014).

Pelo seu possível papel dentro do processo inflamatório crônico a inibição da produção de oxido nítrico tem se mostrado um alvo chave para drogas anti-inflamatórias (DRAGHICIU et al., 2015; KORHONEN et al., 2005).

\subsection{Tratamentos atuais e suas limitações}

O tratamento de processos inflamatórios e lesões de diversas origens é normalmente realizado utilizando Anti-Inflamatórios Não Esteroidais (AINES), e essas moléculas tem atuado como uma importante classe de compostos terapêuticos ao longo dos séculos. O primeiro fármaco desse tipo a ser introduzido no mercado, também sendo o primeiro fármaco a ser sintetizado, ou seja, não derivado diretamente da fonte natural, foi o ácido salicílico, sintetizado pela empresa alemã Bayer e comercializado desde 1899 (PASERO; MARSON, 2010; PATRONO; ROCCA, 2009).

Os mecanismos de ação de tais medicamentos, entretanto, não eram bem compreendidos naquele momento, por mais popular que o medicamento tenha se tornado. Mais de meio século mais tarde, na década de 1970, John Vane descreveu pela primeira vez o mecanismo de ação do ácido acetilsalicílico, passo importante para desenvolver novos 
fármacos dentre os anti-inflamatórios não esteroidais. Ficou então estabelecido que esses fármacos inibiam a enzima prostaglandina $\mathrm{H}$ sintase ou a ciclooxigenase (COX), sendo aplicados em diversas condições inflamatórias, como lesões ligadas a esportes e artrite reumatoide (VANE, 1971, 2000).

Ainda que apresentem vários aspectos positivos, o uso prolongado destas substâncias foi associado a efeitos tóxicos no sistema gastrointestinal que estão relacionados com a inibição da COX-1 pelo uso de AINES, sendo a inibição de prostaglandinas pró-inflamatórias associada com a isoforma COX-2. Os AINES tradicionais, como a aspirina, são caracterizados pela capacidade de inibir, muitas vezes de forma irreversível, ambas as isoformas da COX, levando a danos gástricos pela inibição da isosforma constitutiva, COX-1, que produz prostaglandinas (PGs) gastroprotetoras (HOEFER et al., 2005; MONCADA, S., FERREIRA, S. H. AND VANE, 1973).

$\mathrm{Na}$ tentativa de reduzir os efeitos negativos no trato gastrointestinal, farmacêuticos desenvolveram inibidores seletivos da COX-2, para reduzir ou eliminar os efeitos adversos ligados a esse sistema, que foram introduzidos de forma ampla em 1999. Não obstante outros efeitos negativos foram observados ligados a estas substâncias, sendo a principal preocupação efeitos cardiovasculares que são atribuídos ao desequilíbrio entre prostaciclina e tromboxano (ZILTENER; LEAL; FOURNIER, 2010).

Confrontados com essa adversidade novas abordagem começaram a ser utilizadas pela indústria farmacêutica, focando no desenvolvimento de novos inibidores de ciclooxigenase (COX) e lipoxigenases (LOX), via que não era afetada pelos AINES tradicionais, como o uso de anti-inflamatórios esteroidais (os glicocorticoides) e terapias inibitórias com alvo em citocinas pró-inflamatórias, como o TNF- $\alpha$. Os últimos anos trouxeram bastante progresso nessa área da indústria farmacêutica, porém o desenvolvimento de uma terapia segura, eficaz e economicamente viável prossegue como um grande desafio (RAO; KNAUS, 2008).

A busca pelo desenvolvimento de tais medicamentos anti-inflamatórios seguros e eficazes deve ser uma prioridade global tendo em vista a grande quantidade de pessoas afetadas por doenças inflamatórias crônicas na população mundial. Entretanto, com base na literatura disponível sobre o assunto, são relatados diversos efeitos colaterais relacionados com esses medicamentos, destacam-se: úlceras, osteoporose, falência renal e risco de desenvolvimento de doenças cardiovasculares associados com a utilização de drogas anti-inflamatórias não esteroidais convencionais (AINES) e mesmo inibidores seletivos da COX-2, o que compromete o uso contínuo desses medicamentos no tratamento dessas doenças (SOLEIMANPOUR et al., 2016). 
Dessa forma, o desenvolvimento de compostos anti-inflamatórios novos que levem a menos efeitos secundários ainda permanecem como um desafio para a comunidade científica. Identificar novas drogas ou fontes de medicamentos com a capacidade de promover a resolução do processo inflamatório sem causa grandes danos a homeostase, além de serem modulatórias, eficazes e bem toleradas pelo organismo continua possuindo importância sumaria (DARSHAN; DORESWAMY, 2004; MANI SENTHIL KUMAR et al., 2008; RECIO; ANDUJAR; RIOS, 2012).

2.4 Substâncias derivadas de plantas como alternativas para desenvolvimento de novos fármacos

No início da história da humanidade, os primeiros remédios e tratamentos foram desenvolvidos na base da metodologia da tentativa e erro, sendo as plantas as primeiras fontes de substâncias utilizadas para produzi-los. Todas as culturas humanas, por mais isoladas ou avançadas tecnologicamente, usaram plantas, tinturas ou chás de extratos vegetais para curar doenças que afetavam sua população, obtendo sucesso ou não. Com base nesses experimentos ricas formas de medicina tradicional surgiram pelo globo, baseadas na cultura oral e não na atual medicina de evidências. A interpretação de que nas plantas utilizadas como cura poderiam possuir alguma substância (ou em muitos casos substâncias) que quando isoladas seriam responsáveis pela ação curativa ou benéfica do vegetal é relativamente recente, sendo remetente a meados do século XIX, no contexto do nascimento do que chamamos hoje de ciência moderna, dentro das ciências naturais e farmacêuticas (POLITO et al., 2016; WALTENBERGER et al., 2016).

Nesse período as primeiras substâncias com potencial medicinal começaram a ser isoladas, como a morfina, quinina, colchicina, atropina, pilocarpina, entre outras. Tais substâncias foram fundamentais para o desenvolvimento das ciências da saúde como temos hoje e são usadas até a presente data na farmacoterapia (FÜRST; ZÜNDORF, 2014)

Atualmente, mais de 53.000 espécies de plantas são usadas com propósito medicinal ao redor do globo, sendo que a Organização Mundial da Saúde, em 2011, relatou que por volta de 70-95 \% dos cidadãos de países em desenvolvimento dependem unicamente desses produtos naturais como fonte primária de tratamento para necessidades básicas de saúde, e o gasto com a compra de tais produtos chega a consumir de 15-30 \% de seus salários básicos (HAMILTON, 2004; MALIK et al., 2015; ROBINSON; ZHANG, 2011). 
Atualmente estima-se que cerca de $30 \%$ dos fármacos disponíveis no mercado farmacêutico tenham origem nos produtos naturais, algo possível graças a caracterização de estruturas e mecanismos bioquímicos desses produtos terem sido elucidados ao longo do último século de pesquisa, o que possibilitou o desenvolvimento de novos medicamentos que atuam nas linhas de frente das terapias farmacológicas empregadas pelo mundo (BASSO et al., 2005; NEWMAN; CRAGG; SNADER, 2000).

As plantas medicinais, no atual cenário da indústria farmacêutica, mostram-se uma excelente fonte para moléculas bioativas naturais, de forma que entre 1981 e 2002 aproximadamente metade (49 \%) das Novas Entidades Químicas (NCE, da sigla em inglês) desenvolvidas tiveram como fonte produtos naturais. A grande diversidade espécies vegetais, além da grande diversidade química presente nesses organismos as torna um excelente alvo para isolamento de moléculas e/ou metabólicos primários ou secundários com potencial para utilização farmacológica (OKSMAN-CALDENTEY; INZÉ, 2004; PAN; CHAI; KINGHORN, 2012).

É estimado que aproximadamente um quarto dos fármacos prescritos no globo tenham origem em produtos vegetais, sendo que $11 \%$ dos 252 fármacos considerados essenciais pela Organização Mundial de Saúde (OMS) derivam unicamente de plantas medicinais. Em contraposição, hoje é estimado que existem por volta de 400.000 espécies de plantas vasculares no planeta, das quais apenas 10 \% tiveram caracterização química de algum tipo realizada. Dos 100.000 metabólitos secundários descobertos nesses estudos, provavelmente metade tiveram seus mecanismos de ação totalmente elucidados (CRAGG, G.M.; BOYD, M.R.; GREVER, M.R.; SCHEPARTZ, 1995; OKSMAN-CALDENTEY; INZÉ, 2004; RATES, 2001).

A biodiversidade no planeta não está distribuída de forma homogênea pelo globo. De fato, a ecologia tenta explicar de forma unificada os padrões de distribuição de espécies há anos, sendo que os motivos continuam sendo matéria para debate. É consenso, entretanto, que quanto mais próximo a linha equatorial maior diversidade é encontrada, levando a estimativa de que $70 \%$ de todas as espécies ocorram em países tropicais, nominalmente os 12 a seguir: Austrália, Brasil, China, Colômbia, Equador, Índia, Indonésia, Madagascar, México, Peru e Zaire (BASSO et al., 2005; WHITTAKER; WILLIS; FIELD, 2001).

Nesses países é visível a concentração de florestas tropicais, onde é estimado que mais de $50 \%$ de todas espécies vegetais do planeta encontram-se. O Brasil possui uma posição proeminente no globo em relação a biodiversidade, possuindo grandes área tropicais consideradas hotspot (áreas altamente ameaçadas que contenham cerca de 0,5\% de toda biodiversidade global): a floresta Amazônica (no Norte, compartilhada com outros países da 
América do Sul), a Mata Atlântica (ao longo da costa, hoje não continuamente), o Cerrado (centro do país), a floresta de Araucárias (no Sul), entre outros biomas proeminentes presentes no Brasil (MYERS et al., 2000).

Graças a essa grande disponibilidade de biodiversidade, o Brasil é um pais com posição estratégica para o desenvolvimento de novas drogas e/ou identificação de metabólitos com valor terapêutico, o que por sua vez poderia ser usado como argumento para uso sustentável dessas regiões para evitar perda de espécies com potencial, como tem acontecido atualmente (MYERS et al., 2000; RANGEL et al., 2007). Fármacos anti-inflamatórias utilizadas na terapia atualmente possuem diversas limitações, principalmente em relação a efeitos adversos relacionados a uso continuo ou de longo prazo, problemas de custos, disponibilidade, resposta ineficaz, entre outros. Fica evidente que é necessário desenvolver novos agentes terapêuticos, sendo mais seletivos nos efeitos farmacológicos e com menor toxicidade. O conhecimento sobre seus mecanismos de ação, ainda que tenham avançado, ainda é pequeno. Desvendar mecanismos de ação de produtos naturais é essencial para encontrar novos compostos para utilizar como modelo de novas moléculas terapêuticas (NEWMAN; CRAGG, 2016).

\subsection{Plantas medicinais do cerrado brasileiro e sua atividade}

O Cerrado, também conhecido como savana brasileira, é atualmente o segundo maior bioma brasileiro, abrangendo uma área de aproximadamente 2 milhões de quilômetros quadrados, cerca de $23 \%$ da área total do país. Este bioma abriga cerca de 160.000 espécies de animas, fungos e plantas, que são conhecidos por apresentarem diversos compostos metabólicos de interesse biotecnológico, tanto em possíveis aplicações na indústria alimentícia quanto para a medicina (CARAMORI; LIMA; FERNANDES, 2004; RATTER; RIBEIRO; S., 1997).

Nos últimos anos estudos descobriram atividades biológicas em diversas plantas de famílias típicas do cerrado, Apocynaceae, Sapotaceae, Fabaceae, entre outras. Foram demostrados efeitos benéficos como atividade antimicrobiana, anti-inflamatória e antifúngica nessas plantas, o que demostra um grande potencial na obtenção de substâncias de interesse comercial no cerrado (SILVA; SIMEONI; SILVEIRA, 2009; SOUZA et al., 2012).

$\mathrm{O}$ potencial anti-inflamatório de plantas no cerrado tem sido ligado à presença de triterpenos e flavonoides, que são encontrados em grande quantidade nas plantas da família Sapotacea e suas espécies do gênero Pouteria (SILVA; SIMEONI; SILVEIRA, 2009). 
Outras plantas desse bioma tiveram ação anti-inflamatória comprovada em modelos in vitro, como as da família Flacoutiaceae (Casearia sylvestris) e Sapindaceae (Cupania vernalis e Seriania lethalis) (NAPOLITANO et al., 2005).

\subsubsection{O gênero Pouteria (Sapotaceae Juss.)}

A família Sapotaceae é membro da ordem das Ericales, do filo Angiosperma. São plantas de morfologia variável, com por volta de 53 gêneros descritos englobando 1250 espécies distribuídas por volta do planeta. A maior parte das espécies estão concentradas em regiões tropicais e subtropicais da Ásia e América do Sul. Segundo Carneiro et al. (2015), existem atualmente 12 gêneros, 232 espécies e 27 subespécies dessa família no Brasil (CARNEIRO et al., 2016; SWENSON, U.; ANDERBERG, 2005).

Essa família apresenta diversas espécies com grande relevância comercial, seja por interesse alimentício por meio dos frutos, produção de látex, madeira e derivados, ou pelo seu potencial farmacológico (GAMA; BARBOSA; OLIVEIRA, 2011; PENNINGTON TD, GARDENS RB, 1991; SILVA; SIMEONI; SILVEIRA, 2009). Destaca-se o gênero Pouteria Albl. dentro desta família, que possui cerca de 330 espécies distribuídas pela região neotropical, com registro de 122 espécies no país, com 50 endêmicas, além de 8 subespécies (CARNEIRO, C.E.; ALVES-ARAUJO, A.; ALMEIDA JR., E.B.; TERRA-ARAUJO, 2016; PENNINGTON TD, GARDENS RB, 1991). Nacionalmente esse gênero está distribuído principalmente na região amazônica e no litoral, sendo encontrada frequentemente na Bahia, Espirito Santo, Rio de Janeiro e São Paulo (PENNINGTON, 1991)

O gênero Pouteria é composto por plantas tropicais de porte arbóreo, frutíferas, apresentando frutos com polpa amarela que apresenta entre uma e quatro sementes rígidas. Os frutos são utilizados na alimentação frescos ou após cozimento, podendo ser preparados de outras formas, sendo usados na produção de cremes, sorvetes, batidos, entre outros. Diversas espécies de Pouteria possuem grande quantidade de antioxidantes, compostos polienólicos biologicamente ativos, incluindo ácido gálico, galocatequina, catequina, epicatequina, dihidromiricetina e miricetina (MA et al., 2004).

Além dos usos associados aos frutos, as folhas de algumas espécies de Pouteria também apresentaram potencial anti-inflamatório, sendo na literatura também demostrado efeito protetor de extratos de frutos em danos induzidos no fígado por uso de paracetamol, ainda em resultados preliminares que precisam de maior investigação (ASEERVATHAM et al., 2014). 
Espécies do gênero Pouteria tem sido utilizada em estudos por apresentarem grande potencial farmacológico, sendo associadas a tratamento de inflamações, febres, erupções de pele, úlceras, efeitos larvicidas, efeito neurológico protetor e atividade anti-fúngica (CORREIA et al., 2016; MA et al., 2004; MONTENEGRO et al., 2006).

Essas plantas possuem triterpenos e flavonoides como principais metabólitos secundários (SILVA; SIMEONI; SILVEIRA, 2009), substâncias com diversas propriedades biológicas uteis para aplicação em medicamentos. Em várias espécies foi isolado o Lupeol, triterpeno natural que possui diversas propriedades farmacológicas como ação antiinflamatória, antiartrite, antimutagênico e antitumoral (AGARWAL, R. B.; RANGARI, 2003).

Dados sobre atividade farmacológica e metabólitos secundários do gênero Pouteria são escassos, como afirma Silva (2007), porém tem aumentado devido a vários estudos, que evidenciaram atividades antimicrobiana, citotóxica e imunomoduladora (FONTES JÚNIOR et al., 2009).

Foram estudadas duas espécies pertencentes a esse gênero durante o estudo, Pouteria ramiflora (Mart.) Radlk. e Pouteria torta (Mart.) Radlk., ambas amplamente distribuídas pelo território brasileiro, sendo presentes no bioma amazônico, na Caatinga, Cerrado e Mata Atlântica (ALVES-ARAUJO, 2016).

A espécie Pouteria ramiflora, é uma planta com porte arbóreo, chegando a cerca de 10 metros de altura, presente na região central, sul do Brasil e no norte na Amazônia, onde se espalha ao oeste para a Bolívia, tendo sido registrada no Paraguai mais ao sul. É comum no Cerrado brasileiro, estando presente nas fisionomias de cerradão, cerrado sentido restrito ou strito senso, cerrado ralo, borda de vereda e mata mesofítica ou seca (ALMEIDA, PROENÇA, SANO, 1998; PENNINGTON, GARDENS, 1991).

As coletas das amostras preferencialmente dever ser realizadas para as flores entre abril e dezembro, e frutos entre setembro e fevereiro, em área de campo rupestre, cerrados e matas de galeria. Essa planta é conhecida popularmente pelos nomes louco, massaranduba, leiteiropreto, fruta-do-veado, pessegueiro-do-cerrado, massaranduba-vermelha, entre outros nomes, sendo que existem variações regionais (ALVES-ARAUJO, 2016; E., 2010; SOUZA et al., 2012).

Em estudo realizado por Costa (2014) foram identificados compostos fenólicos, miricetina-3-O- $\beta$-D-galactopiranosídeo e miricetina-3-O- $\alpha$-L-ramnopiranosídeo nas concentrações de 13,55 mg/g e 9,61 mg/g, respectivamente, além de flavonoides a 48,82 mg/g e fenóis a 125,87 mg/g, indicando presença de substâncias com interesse terapêutico. O referido estudo foi feito utilizando extratos hidroalcóolicos. 
Um ensaio realizado por Fontes Junior et al. (2009) utilizando extrato etanólico nas concentrações de 50 e $100 \mathrm{mg} / \mathrm{Kg}$ de $P$. ramiflora evidenciou o efeito anti-inflamatório e analgésico desse extrato em camundongos.

Mais uma vez em camundongos, estudos realizados com esta planta mostram potencialização da ação de enzimas antioxidantes e diminuição de elementos oxidantes em animais diabéticos. $\mathrm{O}$ extrato teria conferido efeito neuroprotetor, sendo que para elucidar tal mecanismo e suas possíveis ações em outras fases da diabetes mais estudos se fazem necessários (COSTA, 2013).

A Pouteria torta, é uma árvore com um longo ciclo de vida, chegando a atingir entre 8 e 14 metros de altura. É típica do Cerrado, podendo também ser encontrada na região amazônica. Seus frutos são utilizados para alimentação e sua casca é popularmente utilizada como anti-disentérico. É conhecida pelas alcunhas de guapeva, abiu-piloso, curiola, aça-ferro, abiu do cerrado, pêssego-do-mato, cabo-de-machado, entre outros (LORENZI, 1992; PERFEITO, 2005).

Além de estar presente no Brasil a Pouteria torta também está presente em outros países da América Latina, incluindo México e Paraguai. Como dito anteriormente, no Brasil essa planta pode ser encontrada no Cerrado, além disso ela também pode ser encontrada em florestas semidecíduas e pluviais, estando presente desde a região amazônica até estados mais ao sul, havendo registros no Goiás, Rio de Janeiro, Minas Gerais, São Paulo, Bahia e Paraná. Estudos realizados na Bahia demonstram que a espécie abrange toda região do cerrado, florescendo entre fevereiro e dezembro e frutificando entre maio e janeiro (QUEIROZ E CARNEIRO, 2010).

Extratos hexânicos e diclorometânicos preparados das flores e frutos de Pouteria torta apresentam $\alpha$ e $\beta$-amirina (que também foi isolada em folhas). Outras substâncias de interesse também foram isoladas nesses extratos, entre elas lupeol, taraxasterol, pseudotaraxasterol, cicloartenos, ácidos graxos, triglicerídeos, hidrocarbonetos de cadeia normal e ramificada, para citar algumas. Nessa espécie foram isolados ainda os ácidos betulínico e ursólico através de extratos metanólicos, substâncias de grande interesse farmacêutico (CHE; KOIKE, 1980; DAVID, 1993; SILVA; SIMEONI; SILVEIRA, 2009).

Diversas outras substâncias foram isoladas a partir de extratos de P. torta, incluindo derivados de glicosídeos classificados como flavonóis, a subclasse mais abundante de flavonoides, que foram isolados a partir de extratos de folhas, e uma proteína chamada pouterina, isolada a partir de sementes da planta. A pouterina tem atividade semelhante à da lecitina, demonstrando atividade antifúngica através de interação com componentes da parede 
celular desses organismos. Essa proteína também demonstrou atividade inseticida e capacidade de induzir aglutinação de eritrócitos em humanos, coelhos e ratos, sendo ainda capaz de induzir apoptose em células de mamíferos (BOLETI et al., 2008; BOLETI et al., 2007; COSTA, 2014).

Existem hoje poucos estudos sobre a caracterização química e biológica de espécies pertencentes ao gênero Pouteria spp., por mais que alguns autores tenham realizado estudos em revisando a família da qual esta planta pertence, Sapotaceae, e o gênero em si. A complexidade morfológica da espécie e falta de especialistas muitas vezes impossibilita o avanço nesses estudos (SILVA; SIMEONI; SILVEIRA, 2009).

O pequeno número de publicações científicas descrevendo a maioria das atividades biológicas propostas para espécies do gênero Pouteria, como descrito por Silva et al. (2009) e evidenciado até o momento no texto reafirmam a finalidade deste estudo, que propõem expandir o conhecimento sobre estas espécies de plantas do Cerrado brasileiro. 


\section{OBJETIVOS}

\subsection{OBJETIVO GERAL}

Avaliar o potencial anti-inflamatório de extratos de plantas das espécies Pouteria torta e Pouteria ramiflora em modelo celular in vitro utilizando células da linhagem J774A.1.

\subsection{OBJETIVOS ESPECÍFICOS}

Verificar a modulação da expressão gênica de marcadores inflamatórios ( $N F k B$, Tnf- $\alpha$, IL-6, iNOS e COX-2), na presença dos extratos de plantas utilizados no estudo.

Confirmar o potencial anti-inflamatório dos extratos de plantas estudados por meio da produção de óxido nítrico (NO). 


\section{MATERIAL E MÉTODOS}

\subsection{Material botânico}

O material vegetal que foi utilizado durante o estudo foi coletado, processados e fornecidos na forma de extrato pelo Laboratório de Produtos Naturais da Faculdade de Ciências da Saúde, da Universidade de Brasília (UnB). São espécies naturais do cerrado brasileiro, mais especificamente aquele proveniente da região do entorno de Brasília. As plantas utilizadas foram identificadas pelo botânico Christopher William Fagg. Vouchers das espécies foram depositados no Herbário da UnB (Tabela 1).

Tabela 1 - Espécies de plantas utilizadas no estudo

\begin{tabular}{llll}
\hline Espécies de Plantas & Nomes Populares & Família & Vouchers \\
\hline Pouteria torta (Mart.) Radlk & "Abiurana-curríola-liso", & Sapotacea & (UB) 3671 \\
& "Guapeva", "Grão-de-Galo" ou & & \\
& "Pateiro" & & \\
\hline Pouteria ramiflora (Mart.) & "Abiu-cutite", "Fruta-do-Veado", & Sapotacea & (UB) 3674 \\
Radlk & "Pessegueiro-do-Cerrado" ou & & \\
& "Massaranduba" & &
\end{tabular}

\subsection{Extração botânica}

Os extratos foram produzidos por desidratação, o que leva a perda de metabolitos voláteis, do material botânico, processo realizado em estufa com circulação de ar à temperatura inferior a $40{ }^{\circ} \mathrm{C}$ durante um período de 7 dias, em seguida as amostras desidratadas foram submetidas a moagem através de moinhos de facas. O pó obtido foi macerado com etanol $95^{\circ}$ com água destilada. A solução obtida foi então concentrada sob a ação de evaporador rotatório, utilizando novamente temperatura inferior a $40{ }^{\circ} \mathrm{C}$, de forma a não comprometer a integridade do material biológico (CORREIA et al., 2008). Os extratos foram estocados para uso na concentração final de $100 \mathrm{mg} / \mathrm{mL}$ (Quadro 2), obtidas solubilizando $100 \mathrm{mg}$ dos extratos em 1 $\mathrm{mL}$ do solvente desejado. 
Tabela 2 - Informações sobre os extratos utilizados

\begin{tabular}{lllll}
\hline Código & Espécies & $\begin{array}{l}\text { Órgão de } \\
\text { Origem }\end{array}$ & Solvente & $\begin{array}{l}\text { Concentração } \\
\text { Final }\end{array}$ \\
\hline PT Et & Pouteria torta & Folhas & Etanol $\left(95^{\circ}\right)$ & $100 \mathrm{mg} / \mathrm{ml}$ \\
\hline PR Aq & $\begin{array}{l}\text { Pouteria } \\
\text { ramiflora }\end{array}$ & Folhas & $\begin{array}{l}\text { Água Ultrapura } \\
\text { Estéril }\end{array}$ & $100 \mathrm{mg} / \mathrm{ml}$ \\
\hline PR Et & $\begin{array}{l}\text { Pouteria } \\
\text { ramiflora }\end{array}$ & Folhas & Etanol $\left(95^{\circ}\right)$ & $100 \mathrm{mg} / \mathrm{ml}$ \\
\hline
\end{tabular}

4.3 Linhagem celular

As células da linhagem J774A.1 American Type Culture Collection (ATCC® TIB$67^{\mathrm{TM}}$ ) foram inicialmente isoladas a partir de ascite desenvolvidos a partir de sarcoma reticular e isoladas após repetidas passagens em camundongos. São células com crescimento em maior parte aderente que mantem características de macrófagos, sendo capazes de produzir óxido nítrico e outros marcadores inflamatórios uma vez estimulados por elementos inflamatórios como o lipopolissacarídeo de Escherichia coli (LPS). É um modelo in vitro largamente usado em ensaios para seleção de substâncias com possível características anti-inflamatórias e posterior análise das vias inflamatórias sinalizadas por macrófagos (MUNIĆ et al., 2011).

\subsection{Cultura de células J774A.1}

Com o objetivo de avaliar os possíveis efeitos anti-inflamatórios dos extratos utilizados durante o estudo e a produção de marcadores inflamatórios foi selecionada a linhagem de macrófagos de murinos J774A.1 (ATCC) TIB-67 adquiridos do Banco de Células Rio de Janeiro (BCRJ)

As células foram submetidas a criopreservação utilizando nitrogênio líquido enquanto solubilizadas em solução de congelamento contendo $5 \%$ de Dimetilsulfóxido (DMSO) e $20 \%$ de Soro Fetal Bovino (SFB). Para realizar os ensaios de estimulação in vitro as células foram descongeladas em banho-maria à temperatura de $37{ }^{\circ} \mathrm{C}$ pelo tempo máximo de 2 minutos até descongelarem completamente, então sendo transferidas para frasco de cultura de células de $75 \mathrm{~cm}^{2}$ contendo meio comercial Dulbecco Modified Eagle Medium (DMEM), suplementado com glicose na concentração de $4500 \mathrm{mg} / \mathrm{L}, 110 \mathrm{mg}$ de Piruvato de Sódio e $2 \mathrm{mM}$ de L- 
glutamina (Sigma-Aldrich Life Science, USA) e $10 \%$ de Soro Fetal Bovino (SFB, Gibco, Invitrogen) anteriormente inativado por calor $\left(56^{\circ} \mathrm{C}\right.$ por $\left.1 \mathrm{~h}\right)$. Também foram adicionados 100 $\mathrm{U} / \mathrm{mL}$ de penicilina-estreptomicina (Sigma-Aldrich), $1 \%$ de aminoácidos não-essenciais (Sigma-Aldrich) e $200 \mu \mathrm{L}$ de HEPES (Ácido Etanosulfônico 4-2-Hidroetil Piperazina-1, Sigma-Aldrich), o qual foi denominado meio DMEM completo.

As células foram armazenadas em estufa à temperatura de $37{ }^{\circ} \mathrm{C}$ contendo $95 \%$ de ar atmosférico e $5 \%$ de $\mathrm{CO}_{2}$, até completa recuperação da linhagem celular. $\mathrm{O}$ meio foi trocado rotineiramente a cada 4 dias. Após atingir confluência de cerca de $90 \%$, sub-cultivos foram realizados obedecendo a taxa de 1:4 recomendada pelo protocolo ATCC de cultivo celular implementado.

A contagem global de células foi realizada utilizando a câmara de Neubauer para contagem total do número de macrófagos J774A.1. Em todos os experimentos realizados durante o estudo as células foram plaqueadas e então cultivadas por 24 horas antes de tratamento com os extratos.

\subsection{Modelo inflamatório da linhagem celular J774A.1 empregado no estudo}

Para fins de controle da ativação dos macrófagos foi utilizado o lipopolissacarídeo presente em membranas de bactérias gram-negativas (LPS) (Lipopolysaccharides from Escherichia coli 055: B5) (Sigma-Aldrich ${ }^{\circledR}$, Life Sciences, St. Louis, EUA) na concentração $1 \mu \mathrm{g} / \mathrm{mL}$. A concentração de LPS utilizada foi definida com base na literatura utilizada e em experimentos prévios (BANJANAC et al., 2012).

Foi também avaliado se o aumento ou diminuição da concentração celular tinha efeito benéfico na produção do óxido nítrico por meio da realização de uma curva com diferentes concentrações de células. Para esse fim uma microplaca de 12 poços foi semeada com diferentes concentrações de células J774A.1, as concentrações usadas nesse experimento foram $5 \times 10^{4}, 5 \times 10^{5}$ e $5 \times 10^{6}$. Após o plaqueamento das células estas foram incubadas durante 24 horas em estufa a $37{ }^{\circ} \mathrm{C}$ com atmosfera de $5 \%$ de $\mathrm{CO}_{2}$ para que chegassem a uma confluência superior a $90 \%$. Cessado o período de incubação o meio DMEM Suplementado foi descartado e então substituído por meio DMEN $5 \%$, com o objetivo de regular a taxa de crescimento das células estudadas, e foi então adicionado LPS na concentração definida anteriormente e a microplaca foi novamente incubada nas condições anteriormente descritas. Foi então coletado o sobrenadante dessas culturas nos tempos de 6, 24, 48 e 72 horas, para posterior análise de produção de mediadores inflamatórios. 
Uma vez definidos o parâmetro avaliado no experimento acima foi definido o modelo para cultura de células nas próximas etapas do projeto. Para tais ensaios as células foram cultivadas como foi anteriormente descrito, em estufa a $37{ }^{\circ} \mathrm{C}$ e atmosfera de $5 \%$, e então semeadas em microplacas de 12 poços, na concentração de $5 \times 10^{6}$, sendo então incubadas por 24 horas. Em seguida o meio DMEN Suplementado foi descartado e substituído pelo meio DMEN $5 \%$ e as células foram estimuladas com o LPS na concentração de $1 \mu \mathrm{g} / \mathrm{mL}$ para promover inflamação das células.

Após 3 horas foi então adicionado $200 \mu \mathrm{L}$ dos extratos nas concentrações 5, 2,5, 1,25, $0,625,0,313,0,156,0,078,0,039$ e $0,020 \mathrm{mg} / \mathrm{mL}$ pré-definidas, sendo então incubadas nas condições anteriormente descritas. O sobrenadante das culturas foi então coletado após os tempos de 24 e 48 horas, sendo então armazenados a $-20{ }^{\circ} \mathrm{C}$ devidamente identificados para possibilitar a análise de produção de óxido nítrico. Todos os ensaios realizados nesse estudo foram feitos em triplicata.

4.6 Delineamento experimental

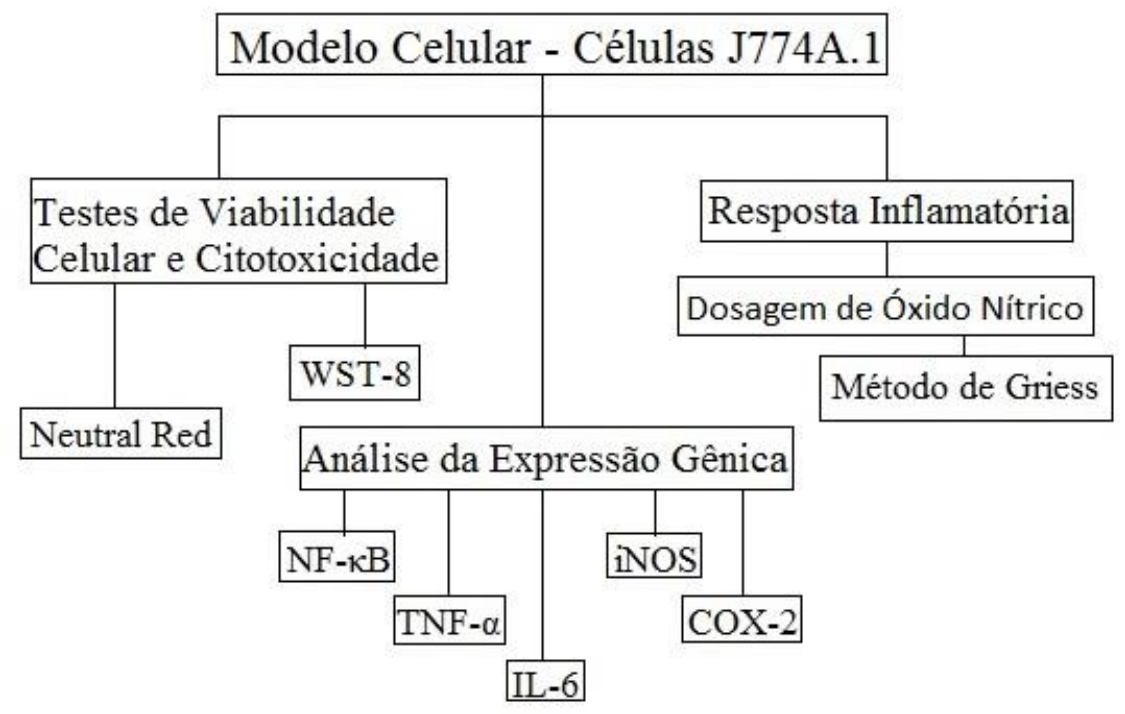

Figura 3 - Delineamento Experimental desenvolvido durante o trabalho 
4.7 Avaliação de viabilidade celular após interação com os extratos de plantas

\subsubsection{Ensaio de WST-8}

Para analisar os efeitos citotóxicos dos extratos nas células utilizadas durante o estudo foi utilizado o método WST-8 (Cell Counting Kit-8) (Sigma-Aldrich®, St. Louis, EUA), um método bastante similar ao 3-(4,5-Dimetiltiazol-2-il)2,5-Difenil Brometo de Tetrozólio, Methyl-Thiazolyl-Tetrozalium (MTT), um método colorimétrico amplamente utilizado em estudos na literatura.

O método do MTT é um ensaio baseado na clivagem de anéis de tetrazólio presentes na estrutura química desta substância, realizada pela enzima desidrogenase mitocondrial, resultando na produção de cristais de formazan, insolúveis em agua e com uma coloração violeta. Esses cristais são extraídos das células utilizando-se dimetilsulfóxido (DSMO). O ensaio apenas será reativo em células viáveis, uma vez que aquelas inviáveis não apresentarão atividade mitocondrial o que inviabiliza a clivagem do reagente (FERREIRA et al., 2013).

O ensaio de WST-8 [2- (2-metoxi-4-nitrofenil) -3- (4-nitrofenil) -5- (2,4-dissulfofenil) 2H-tetrazólio], também resulta na produção de cristais de formazan sob a ação da desidrogenase mitocondrial, mas ao contrário do que acontece no ensaio clássico de MTT os cristais formados são solúveis em água, não sendo necessário o emprego de DMSO ou qualquer outro solvente para a dissolução dos cristais formados, o que torna o método mais sensível que o MTT, comumente empregado. Em ambos os ensaios, o número de células sobreviventes é proporcional à quantidade de formazan e é quantificável pela cor da solução, motivo pelo qual a técnica é colorimétrica. A cor pode ser quantificada em espectrofotômetro ou leitor de microplacas (FERREIRA et al., 2013).

Para realizar o ensaio de citotoxicidade as células foram semeadas numa concentração de 1 x $10^{5}$ em placas de 96 poços, cultivadas então em DMEM suplementado e incubadas a 37 ${ }^{\circ} \mathrm{C}$ em estufa com $5 \% \mathrm{CO}_{2}$ por um período de 24 horas. Após o referido intervalo o meio foi substituído por $180 \mu \mathrm{L}$ de meio DMEM suplementado apenas com $5 \%$ de SFB e então foi adicionado $20 \mu \mathrm{L}$ das concentrações a serem testadas dos extratos de plantas. Os extratos de Pouteria torta e Pouteria ramiflora estavam diluídos nas seguintes concentrações: 5, 2,5, 1,25, $0,625,0,313,0,156,0,078$ e $0,02 \mathrm{mg} / \mathrm{mL}$.

Depois da adição dos extratos, a cultura de células foi homogeneizada e a microplaca foi novamente incubada nas mesmas condições descritas. Após mais 24 horas o meio foi então 
descartado e substituído por $100 \mu \mathrm{L}$ de meio DMEM incolor (sem a presença de vermelho de fenol, presente no DMEM suplementado) suplementado com $5 \%$ de SFB, e, em seguida, 10 $\mu \mathrm{L}$ de WST-8 foi adicionado em cada poço. Nesse ensaio, para o controle positivo, foi utilizado células estimuladas com LPS e sem tratamento com os extratos. Para o controle de morte celular foram utilizadas células estimuladas com LPS e tratados com $10 \mu \mathrm{L}$ de DMSO $20 \%$. Para funcionar como o branco (padrão para o espectrofotômetro) foi usado o próprio meio DMEM incolor sem células. Após 4 horas de incubação com o WST-8, foi medida a absorbância das amostras em espectrofotômetro (Thermo Plate TP-Reader) utilizando filtro no comprimento de onda de $450 \mathrm{~nm}$. Para descartar interação química entre o extrato e o reagente de WST-8 foi realizado um ensaio utilizando WST-8 e cada uma das concentrações dos extratos testados, sem a presença de células.

\subsubsection{Ensaio de Vermelho Neutro}

O segundo ensaio empregado para avaliação da citotoxicidade dos extratos foi o de incorporação de vermelho neutro, que é um teste que avalia a sobrevivência e viabilidade celular baseada na capacidade das células sobrevivente de absorver o reagente vermelho neutro, um corante supravial, catiônico fraco que penetra facilmente nas membranas celulares por um mecanismo distinto da difusão, acumulando-se intracelularmente nos lisossomos, onde se liga aos sítios de matriz lisossomal aniônica. Alterações nas membranas plasmática ou lisossomal leva a fragilidade do lisossomo e outras mudanças que gradualmente podem tornar-se irreversíveis, levando até mesmo a morte celular. Tais alterações causadas pela ação de xenobióticos resultam numa redução da absorção e ligação do vermelho neutro, portanto, é possível distinguir células mortas, danificadas e vivas, fato que será a base para esse ensaio (MATTANA, 2014).

Para avaliar a viabilidade das células estimuladas pelos extratos, nos termos de integridade lisossomal, foi realizado o ensaio de vermelho neutro conforme descrito por Taner et al. (2013), com algumas modificações descritas a seguir. As células foram plaqueadas em microplacas de 96 poços numa concentração de 1 x 10 , em meio DMEM suplementado e foram incubadas a $37{ }^{\circ} \mathrm{C}$ em estufa com $5 \%$ de $\mathrm{CO}_{2}$. Após 24 horas o meio foi trocado por 180 $\mu \mathrm{L}$ de meio DMEM incolor contendo $5 \%$ de SFB, e $20 \mu \mathrm{L}$ dos extratos (PT Et, PR Aq e PR Et) nas concentrações: 5, 2,5, 1,25, 0,625, 0,313, 0,156, 0,078 0,039, 0,020 mg/mL. Em seguida a microplaca foi novamente incubada por 24 horas nas mesmas condições referidas acima. 
Após o mencionado tempo de incubação com os extratos o meio foi removido e as células foram lavadas três vezes com $300 \mu \mathrm{L}$ da solução tampão fosfato salino (PBS - pH 7.4) e 100 $\mu \mathrm{L}$ de meio DMEM suplementado com $50 \mu \mathrm{g} / \mathrm{mL}$ de vermelho neutro foram adicionados aos poços. A microplaca foi então incubada a $37{ }^{\circ} \mathrm{C} \operatorname{com} 5 \%$ de $\mathrm{CO}_{2}$ por 3 horas, após esse período, o meio foi descartado e as células foram lavadas 5 vezes com $300 \mu \mathrm{L}$ PBS a fim de remover o excesso de corante não incorporado às células e $100 \mu \mathrm{L}$ de solução de álcool-ácido $(50 \%$ de etanol, $1 \%$ de ácido acético e $49 \%$ de água destilada) foram adicionadas em cada poço para fixar o vermelho neutro nas células. A placa foi agitada por 10 minutos e a absorbância de cada amostra foi lida em leitor de microplacas a $492 \mathrm{~nm}$. Os resultados foram expressos como uma porcentagem das células não tratadas, usando a equação:

Viabilidade $(\%)=\left(n^{\circ}\right.$ de células viáveis/número total de células $) X 100$.

\subsection{Dosagem de Óxido Nítrico (NO)}

A produção de espécies reativas de nitrogênio, em especial o Óxido Nítrico (NO), é um regulador produzido da ativação de macrófagos. A produção de NO está intimamente ligada com produção de algumas citocinas e outros estímulos imunológicos, como o LPS. Para analisar a produção de óxido nítrico foi aplicado o método de Griess. O método consiste em combinar dois reagentes, a Sufanilamida dissolvida em ácido fosfórico a $5 \%$, e 0,1 \% de N-1naftil-ethylendiamide-dicloridrato (NEED) em água, formando o reagente de Griess, que então se liga ao nitrito, um óxido derivado do Óxido Nítrico. Para o experimento foram semeadas 5 x $10^{6}$ células em placas de 12 poços, que foram incubadas durante 24 horas. Após esse período as células foram tratadas com os extratos das plantas. Após 3 horas, conforme o protocolo de inflamação anteriormente definido, as células foram estimuladas com $10 \mu \mathrm{L}$ LPS na concentração $1 \mu \mathrm{L} / \mathrm{mL}$ por poço. Foram então coletadas amostras do sobrenadante das culturas. Em seguida foi adicionado $100 \mu \mathrm{L}$ do reagente de Griess e o resultado foi analisado em leitora de microplacas utilizando o filtro de $450 \mathrm{~nm}$ e os resultados expressos em $\mu \mathrm{mol} / \mathrm{L}$ de NO2comparando-se a densidade ótica (D.O.) obtida com uma curva padrão de $\mathrm{NO}_{2}$ - variando de 3,125 a 200,0 $\mu \mathrm{mol} / \mathrm{L}$ (GREEN et al., 1981). 


\subsubsection{Extração e Purificação do RNA}

O Kit Direct-zolTM RNA Miniprep (R2051, Zymo Research, USA) foi escolhido para realizar a extração e purificação do RNA obtido durante os experimentos descritos a seguir, seguindo as recomendações do fabricante. O método consiste em inicialmente extrair o material genético alvo usando o reagente Trizol, uma solução monofásica de fenol e isotiocianato de guanidina, que atua rompendo a célula sem comprometer a integridade do RNA presente.

Para realizar essa etapa, células J774A.1 foram semeadas em garrafas de cultura de células com $25 \mathrm{~cm}^{2}$ de área com $7 \times 10^{5}$. Foi usado o meio DMEM Suplementado para incubação, que durou até que as células atingissem um mínimo de $90 \%$ de confluência. Após esse período o meio foi então descartado e substituído por $3 \mathrm{~mL}$ de meio DMEM contendo 5 $\%$ de SFB. As células foram então tratadas com os extratos de plantas nas diluições $0,78,0,39$ e $0,19 \mathrm{mg} / \mathrm{mL}$ e após 3 horas foi adicionado $30 \mu \mathrm{L}$ de LPS para atingir a concentração de 1 $\mu \mathrm{L} / \mathrm{mL}$. Após 48 horas de tratamento, durante o qual as células foram mantidas em estufa a $37^{\circ} \mathrm{C}$ em atmosfera de $5 \%$ de $\mathrm{CO}_{2}$, o sobrenadante das culturas foi coletado e armazenado em microtubos de $0,5 \mathrm{~mL}$, que foram então congelados a $-20{ }^{\circ} \mathrm{C}$ para serem posteriormente utilizados para dosagem de óxido nítrico. Em seguida o restante do meio nas garrafas foi descartado e $1 \mathrm{~mL}$ de Trizol, TRI Reagent ${ }^{\circledR}$ (Sigma-aldrich, Life Science), foi adicionado ao tapete celular e então foi homogeneizado por pipetagem de forma a promover a lise celular. $\mathrm{O}$ lisado foi então transferido para microtubos de $2 \mathrm{~mL}$ e armazenado a $-20{ }^{\circ} \mathrm{C}$.

No dia seguinte a purificação do RNA foi realizada utilizando-se o kit Direct-ZolTM RNA MiniPrep. O lisado celular ( $1 \mathrm{~mL})$ obtido anteriormente foi descongelado por 5 minutos a temperatura ambiente para permitir dissociação completa dos complexos de nucleoproteínas. Depois de descongelado o lisado celular foi transferido para um novo microbulo e $1 \mathrm{~mL}$ de etanol estéril a $95 \%$ foi adicionado. O conteúdo foi homogeneizado e agitado vigorosamente por 15 segundos e então transferido para coluna de sílica, sendo então centrifugado a $11.000 \mathrm{~g}$ por 1 minuto. Em seguida o filtrado foi descartado e a coluna transferida para novo microtubo e $400 \mu \mathrm{L}$ de solução de lavagem (RNA Wash Buffer) foi adicionado a coluna, que foi novamente centrifugada a $11.000 \mathrm{~g}$ por mais 1 minuto. A coluna foi então transferida para novo microtubo para dar início a purificação do RNA. 
Para o processo de purificação de RNA foi adicionado à coluna $80 \mu \mathrm{L}$ de DNAse (cocktel DNAse) aplicados diretamente no filtro para eliminar qualquer fragmento indesejado de DNA. Em seguida os tubos e coluna foram incubados em estufa a temperatura de $37^{\circ} \mathrm{C} \mathrm{em}$ atmosfera de $5 \%$ de $\mathrm{CO}_{2}$ por 15 minutos. Após esse tempo os microtubos foram centrifugados a $11.000 \mathrm{~g}$ por 30 segundos. O próximo passo consistiu em adicionar à coluna $400 \mu \mathrm{L}$ de solução pré-lavagem (RNA pre-wash buffer) e então uma nova centrifugação foi realizada, $11.000 \mathrm{~g}$ por 1 minuto. O filtrado foi novamente descartado e esse passo foi novamente repetido. Posterior a repetição foi adicionado à coluna $700 \mu \mathrm{L}$ de solução de lavagem (RNA wash buffer) e nova centrifugação a $11.000 \mathrm{~g}$ por 2 minutos foi realizada. O filtrado foi então descartado e em seguida foi repetida a mesma centrifugação com a coluna vazia. A coluna foi então transferida para novo microtubo que foi anteriormente purificado de RNAse e recebeu a adição de $22 \mu \mathrm{L}$ de água ultrapura (Invitrogen, Life Technologies). Para liberar o RNA purificado de coluna de sílica uma nova centrifugação, dessa vez a $13.500 \mathrm{~g}$ por 2 minutos, foi realizada. O filtrado foi coletado e transferido para um microtubo de 1,5 $\mathrm{mL}$, que foi devidamente identificado para dar-se prosseguimento para a etapa de quantificação do RNA.

\subsubsection{Análise do RNA extraído}

Para assegurar a qualidade do RNA obtido foi utilizado eletroforese em gel de agarose a $1 \%$ corado com brometo de etídio $(0,5 \mu \mathrm{g} / \mathrm{mL})$. A quantificação do RNA extraído foi determinada através do espectrofotômetro NANODROP ND-100 (Thermoscientific, Walthan, EUA). Para avaliar o grau de pureza das amostras foi considerada a razão da absorvência em dois comprimentos de onda nas densidades óticas (DO) A260/280 nm (utilizada para avaliar contaminação proteica) e $\mathrm{A}_{260 / 230} \mathrm{~nm}$ (utilizada para avaliar a contaminação por compostos orgânicos em geral). Quando a razão dessas densidades óticas foi superior a 1,9 o grau de pureza do RNA foi considerado adequado para a realização das análises. Depois de quantificado no espectrofotômetro o RNA total foi estocado à $-80^{\circ} \mathrm{C}$ para posterior síntese de cDNA. 


\subsubsection{Sintese de cDNA}

Para realizar a síntese do cDNA foi utilizado o kit Highcapacity cDNA Reverse Transcription Kit (Applied Biosystems, USA), seguindo as recomendações do fabricante. Uma quantidade de $2 \mu \mathrm{g}$ de RNA foram submetidas à reação de transcrição reversa (RT) em cada uma das amostras onde tal quantidade foi observada.

Após o cDNA ter sido sintetizado as amostras foram diluídas para que a concentração final de $6 \mathrm{ng} / \mu \mathrm{L}$ fosse obtida de forma a padronizar a quantidade de amostra a ser pipetada em cada reação de qPCR. Após a padronização foi possível determinar que cada reação seria realizada com $36 \mathrm{ng} / \mu \mathrm{L}$ de cDNA e o erro de pipetagem pode ser considerado reduzido ao máximo, o que possibilitou o emprego de um pipetador automático. Os microtubos contendo o cDNA produzido nessas reações foi armazenado a $-20^{\circ} \mathrm{C}$ para posterior análise.

\subsubsection{Definição dos genes de Interesse}

Os genes selecionados para essa etapa do estudo são genes ligados a regulação de atividade inflamatória que foram considerados satisfatórios para produção de respostas adequadas aos objetivos propostos no estudo. Foram utilizados 6 primers sintetizados pela Integrated DNA Technologies (IDT), melhor descritos na tabela a seguir. Tais pares de primers foram desenhados de acordo com a literatura, sendo utilizado o programa Primer Express (Applied Biosystems) e com base nas sequências obtidas da base de dados do transcriptoma de camundongo (http://www.informatics.jax.org). 
Tabela 3 - Genes analisados no estudo

\begin{tabular}{|c|c|}
\hline $\begin{array}{l}\text { Símbolo do } \\
\text { Gene }\end{array}$ & Descrição \\
\hline \multirow{2}{*}{ GAPDH } & Gliceraldeído-3-Fosfato \\
\hline & Desidrogenase \\
\hline $\mathrm{COX}-2$ & Ciclooxigenase 2 \\
\hline$I L-6$ & Interleucina 6 \\
\hline iNOS & Óxido Nítrico Sintetase Induzida \\
\hline$N F \kappa B$ & Fator Nuclar kappa B \\
\hline$T N F-\alpha$ & Fator de Necrose Tumoral Alfa \\
\hline
\end{tabular}

\subsubsection{Padronização das concentrações dos Primers}

Para realização dos experimentos de qPCR foi utilizado o equipamento StepOnePlus ${ }^{\mathrm{TM}}$ (Applied BioSystems - Life Technologies ${ }^{\mathrm{TM}}$, Carlsbad, USA). Para determinar o desempenho das reações de PCR comparando-se diferentes condições experimentais e ensaios foi necessário a realização da otimização do protocolo de reação usado durante o estudo. Diversos fatores foram levados em conta durante a avaliação para que pudesse ser obtido maior precisão e confiabilidade nos resultados produzidos: 1) Precisão que é determinada e passível de ser corrigida quando a reação é feita em triplicata; 2) Eficiência, indicada pela inclinação (slope) da curva padrão e de outros parâmetros como R2 e $Y$-interceptor (ponto em que a curva corta o eixo Y), estes são calculados pela diluição seriada, demonstrando o quanto um valor é consegue predizer outro valor, estabelecendo uma boa confiança na correlação de dois valores, e; 3) Sensibilidade da análise estatística, onde um grande número de replicatas é necessário para prover significância estatística.

Após determinar o desempenho das reações que foram realizadas no equipamento disponível para uso, foi necessária a otimização do protocolo de qPCR e quantificação relativa, que foi feita pelo método $\Delta \Delta \mathrm{Ct}$. Inicialmente foi realizado a titulação dos primers, ou experimento de Matriz de primers. Nesse experimento são utilizadas diferentes concentrações de cada primer reagindo com uma mesma amostra de cDNA. A concentração considerada ideal é logicamente aquela que apresenta melhor rendimento, em outras palavras, um menor valor de threshold cycle $(\mathrm{Ct})$ e maior $\Delta \mathrm{RN}$. Durante a realização do experimento de titulação ainda 
é possível detectar formação de dímeros de primers e especificidade da reação, verificando a formação de uma curva de melting única.

Após o término da titulação foi iniciado o experimento de eficiência da reação, desenhado para garantir que o protocolo da reação está otimizado em relação às concentrações dos componentes e se os primers desenhados para o estudo estão corretos. Em uma reação com eficácia dentro do esperado deve apresentar eficiência em um intervalo entre 90 e $110 \%$. Qualquer variação fora do esperado indica algum problema na reação em si ou que os primers não são adequados para o uso. É necessário garantir a eficiência da reação para que os resultados gerados possam ser comparáveis com outros e precisos. 
Tabela 4 - Sequência dos Primers dos genes utilizados no estudo em reações de qPCR

\begin{tabular}{|c|c|c|c|}
\hline Símbolo do Gene & Sentido & Sequência (5'-3') & Temperatura \\
\hline Alvo & de & & Média de \\
\hline & Leitura & & Anelamento \\
\hline GAPDH & Forward & CCG GTG CTG AGT ATG TCG & $85,75^{\circ} \mathrm{C}$ \\
\hline & Reverse & CCC TGT TGC TGT AGC CGT A & \\
\hline$C O X-2$ & Forward & TGA GTA CCG CAA ACG CTT CTC & $80,35^{\circ} \mathrm{C}$ \\
\hline & Reverse & TGG ACG AGG TTT TTC CAC CAG & \\
\hline$I L-6$ & Forward & GCT ACC AAA CTG GAT ATA & $73,48^{\circ} \mathrm{C}$ \\
\hline & & ATC AGG A & \\
\hline & Reverse & CAG GTA GCT ATG GTA CTC & \\
\hline & & CAG AA & \\
\hline$i N O S$ & Forward & GGC AGC CTG TGA GAC CTT TG & $77,81^{\circ} \mathrm{C}$ \\
\hline & Reverse & GCA TTG GAA GTG AAG CGT & \\
\hline & & TTC & \\
\hline$N F \kappa B$ & Forward & AGC CAG CTT CCG TGT TTG TT & $77,81^{\circ} \mathrm{C}$ \\
\hline & Reverse & AGG GTT TCG GTT CAC TAG TTT & \\
\hline & & $\mathrm{CC}$ & \\
\hline
\end{tabular}

\begin{tabular}{lll}
\hline TNF- $\alpha$ & Forward & TCT TCT CAT TCC TGC TTG TGG \\
\cline { 2 - 3 } & Reverse & GGT CTG GGC CAT AGA ACT GA
\end{tabular}${ }^{\circ} \mathrm{C}$

4.9.6 Titulação dos Primers

As sequências dos primers dos genes GAPDH, COX-2, IL-6, iNOS, NF-kB e TNF- $\alpha$ foram obtidas para expressão gênica via $\Delta \Delta \mathrm{Ct}$ por SYBR Green, gerando as sequências forward e reverse (Tabela 4). 
A concentração considerada ideal de primers para utilização na reação de qPCR deve ser a mínima capaz de promover a duplicação de todas as cópias do gene presentes na amostra utilizada. Para determinar tal concentração foram realizadas reações com a mesma quantidade de amostras de células estimuladas durante 48 horas com LPS utilizando as concentrações de 100,300 e 600 nM de cada primer, tanto na cópia forward e reverse de cada um desses primers. Para quantificar cada uma dessas reações foi utilizado o método Quantification - Relative Standard Curve. As concentrações consideradas ótimas foram as que o gene de interesse apresentou Cycle threshold ou ciclo limiar $(C t)$ e $\Delta \mathrm{RN}$ maior que 1, sem formação de dímeros. $\mathrm{Na}$ tabela a seguir estão listadas as condições ótimas que foram padronizadas para cada um dos pares de primers a partir dos ensaios realizados.

Tabela 5 - Threshold, quantidade de primers e de cDNA e condições de termociclagem padronizadas para cada um dos primers a partir dos ensaios de curva padrão e otimização para amplificação por qPCR Nome do Gene Cycle Quantidade de primer Quantidade de Número de ciclos

\begin{tabular}{lllll} 
& Threshold & $(\mathrm{nM})$ & cDNA $(\mathrm{ng})$ & de desnaturação \\
\hline $\boldsymbol{G A P D H} \boldsymbol{F}$ & 2,22 & $300 \mathrm{nM}$ & 100 & 40 \\
\hline $\boldsymbol{G A P D H} \boldsymbol{R}$ & 2,22 & $300 \mathrm{nM}$ & 100 & 40 \\
\hline $\boldsymbol{C O X}-\boldsymbol{2} \boldsymbol{F}$ & 0,73 & $300 \mathrm{nM}$ & 100 & 40 \\
\hline $\boldsymbol{C O X}-\mathbf{2} \boldsymbol{R}$ & 0,73 & $300 \mathrm{nM}$ & 100 & 40 \\
\hline $\boldsymbol{I L - 6} \boldsymbol{F}$ & 1,30 & $600 \mathrm{nM}$ & 100 & 40 \\
\hline $\boldsymbol{I L - 6} \boldsymbol{R}$ & 1,30 & $100 \mathrm{nM}$ & 100 & 40 \\
\hline $\boldsymbol{i N O S} \boldsymbol{F}$ & 1,02 & $300 \mathrm{nM}$ & 100 & 40 \\
\hline $\boldsymbol{i N O S} \boldsymbol{R}$ & 1,02 & $300 \mathrm{nM}$ & 100 & 40 \\
\hline $\boldsymbol{N F}-\boldsymbol{\kappa B} \boldsymbol{F}$ & 0,80 & $600 \mathrm{nM}$ & 100 & 40 \\
\hline $\boldsymbol{N F}-\boldsymbol{\kappa} \boldsymbol{B} \boldsymbol{R}$ & 0,80 & $600 \mathrm{nM}$ & 100 & 40 \\
\hline $\boldsymbol{T N F}-\boldsymbol{\alpha} \boldsymbol{F}$ & 1,40 & $600 \mathrm{nM}$ & 100 & 40 \\
\hline $\boldsymbol{T N F}-\boldsymbol{\alpha} \boldsymbol{R}$ & 1,40 & $300 \mathrm{nM}$ & 100 & 40 \\
\hline
\end{tabular}

\subsubsection{Ensaio de Eficiência}

Após ser estabelecido a quantidade ideal de primers a ser utilizada em cada ensaio foi então realizado o ensaio de eficiência da reação, de forma a verificá-la. Grandes quantidades de cDNA foram necessárias para possibilitar esse experimento. Cada amostra foi obtida pela 
extração de células em cultivo que foram inflamadas com LPS, o que resultou na expressão de cada um dos genes que foi analisado. Foram realizados seis ensaios com diferentes concentrações de cDNA, sendo elas 200 ng, 100 ng, 25 ng, 12,5 ng e 6,25 ng de DNA diluído em água ultrapura (Invitrogen, Life techologies). Todas as reações foram quantificadas pelo método Quantification - Relative Standard Curve ou quantificação relativa.

\subsubsection{Reação em Cadeia da Polimerase quantitativa em Tempo Real (qPCR)}

Para realizar a detecção da expressão gênica por qPCR foi utilizado o sistema SYBR Green Máxima SYBR Green/Rox qPCR (Thermo scientific, USA), de uso já padronizado pela equipe de pesquisa. Para cada reação foi utilizado $10 \mu \mathrm{L}$ de SYBR Master Mix (concentração inicial $2 \mathrm{x}$ ), $2 \mu \mathrm{L}$ de cada um dos sentidos dos primers (forward e reverse, $5 \mu \mathrm{M}$ de cada); $6 \mu \mathrm{L}$ de cDNA (36 ng) e água ultrapura (Invitrogen, Life techologies) suficiente para completar o sistema para $20 \mu \mathrm{L}$. Todos os ensaios de amplificação foram realizados em placas de 96 poços na plataforma StepOnePlus Real-Time PCR System (Applied biosystems, USA). As reações foram padronizadas em 10 minutos de amplificação a $95{ }^{\circ} \mathrm{C}$ seguidos por 40 ciclos de 15 segundos também a $95{ }^{\circ} \mathrm{C}, 1$ minuto a $60{ }^{\circ} \mathrm{C}$ para anelamento e 30 segundos a $72{ }^{\circ} \mathrm{C}$ para alongação. O gene $G A P D H$ foi utilizado como controle endógeno e os valores de $C t$ foram obtidos segundo o método $2-\Delta \Delta \mathrm{Ct}$.

\subsubsection{Expressão gênica}

Para analisar a expressão gênica dos marcados inflamatórios estudados os dados de quantificação relativa (Fold Change) foram calculados pelo método $\Delta \Delta \mathrm{Ct}$, metodologia que permite comparação relativa entre o grupo usado como controle negativo (grupo não recebeu o estimulo inflamatório). Nesse estudo os grupos calibradores foram nomeados NT (que não recebeu tratamento algum) e grupo LPS (que recebeu tratamento apenas com LPS), o controle positivo desses experimentos.

Para facilitar a apresentação desses dados foi utilizada a seguinte terminologia apresentada na tabela a seguir: 
Tabela 6 - Grupos Controle utilizados no estudo

\section{Código do Grupo Descrição}

\begin{tabular}{|c|c|}
\hline NT & Não recebeu estímulo, Controle Negativo \\
\hline LPS & Estímulo com LPS, Controle Positivo \\
\hline PT Et 1 & $\begin{array}{l}\text { Tratamento com extrato etanólico de Pouteria torta na concentração de } \\
0,078 \mathrm{mg} / \mathrm{mL}\end{array}$ \\
\hline PT Et 2 & $\begin{array}{l}\text { Tratamento com extrato etanólico de Pouteria torta na concentração de } \\
0,039 \mathrm{mg} / \mathrm{mL}\end{array}$ \\
\hline PT Et 3 & $\begin{array}{l}\text { Tratamento com extrato etanólico de Pouteria torta na concentração de } \\
0,020 \mathrm{mg} / \mathrm{mL}\end{array}$ \\
\hline PR Aq 1 & $\begin{array}{l}\text { Tratamento com extrato aquoso de Pouteria ramiflora na concentração } \\
\text { de } 0,078 \mathrm{mg} / \mathrm{mL}\end{array}$ \\
\hline PR Aq 2 & $\begin{array}{l}\text { Tratamento com extrato aquoso de Pouteria ramiflora na concentração } \\
\text { de } 0,039 \mathrm{mg} / \mathrm{mL}\end{array}$ \\
\hline PR Aq 3 & $\begin{array}{l}\text { Tratamento com extrato aquoso de Pouteria ramiflora na concentração } \\
\text { de } 0,020 \mathrm{mg} / \mathrm{mL}\end{array}$ \\
\hline PR Et 1 & $\begin{array}{l}\text { Tratamento com extrato etanólico de Pouteria ramiflora na } \\
\text { concentração de } 0,078 \mathrm{mg} / \mathrm{mL}\end{array}$ \\
\hline PR Et 2 & $\begin{array}{l}\text { Tratamento com extrato etanólico de Pouteria ramiflora na } \\
\text { concentração de } 0,039 \mathrm{mg} / \mathrm{mL}\end{array}$ \\
\hline PR Et 3 & $\begin{array}{l}\text { Tratamento com extrato etanólico de Pouteria ramiflora na } \\
\text { concentração de } 0,020 \mathrm{mg} / \mathrm{mL}\end{array}$ \\
\hline
\end{tabular}


Grupo calibrador 1:

- LPS/NT representa o número de vezes que o gene é mais (+) ou menos (-) expresso no Grupo estimulado com LPS em relação ao Grupo NT, a fim de avaliarmos se o estímulo induzido com LPS altera a expressão dos genes em estudo.

- Extratos/NT ou PT Et 1, PT Et 2, PT Et 3, PR Aq 1, PR Aq 2, PR Aq 3, PR Et 1, PR Et 2, PR Et 3/NT representa o número de vezes que o gene é mais (+) ou menos (-) expresso nos Grupos tratados com os extratos em relação ao NT, a fim de avaliarmos se os extratos utilizados alteram a expressão dos genes em estudo.

Grupo calibrador 2:

- LPS/Extratos ou ou LPS/PT Et 1, PT Et 2, PT Et 3, PR Aq 1, PR Aq 2, PR Aq 3, PR Et 1, PR Et 2, PR Et 3 representa o número de vezes que o gene é mais (+) ou menos (-) expresso nos Grupos extratos em relação ao Grupo LPS, a fim de avaliarmos se os extratos utilizados no tratamento das células inflamadas com LPS alteram a expressão dos genes em estudo. 


\section{RESULTADOS}

5.1 Avaliação de diferentes concentrações celulares numa cinética de ativação da linhagem celular J774A. 1 com $1 \mu \mathrm{g} / \mathrm{mL}$ de LPS

A concentração de células por poço utilizada poderia influenciar na produção de óxido nítrico. Assim, com a finalidade de avaliar se o estímulo de LPS selecionado com base na literatura pertinente era adequado a tal concentração, foi construída uma curva de concentração de células, todas estimuladas com $1 \mu \mathrm{g} / \mathrm{mL}$ para avaliar qual concentração celular apresentava a melhor produção de óxido nítrico.

Foram utilizadas as concentrações de $5 \times 10^{4}, 5 \times 10^{5}$ e $5 \times 10^{6}$ nos tempos de 6, 24, 48 e 72 horas em placas de 12 poços. O tempo de 72 horas foi descartado pois as células visivelmente desprenderam-se do fundo da placa, tonando a medição da densidade ótica (DO) imprecisa. De acordo com os resultados apresentados na Figura 4, não houve diferença significativa na produção de oxido nítrico em função da variação da concentração celular ou de tempo, tendo sido selecionado então o tempo de 48 horas com a concentração de $5 \times 10^{6}$, concentração verificada em trabalhos anteriores na literatura disponível e padronizada em outros experimentos realizados pela equipe de pesquisa.

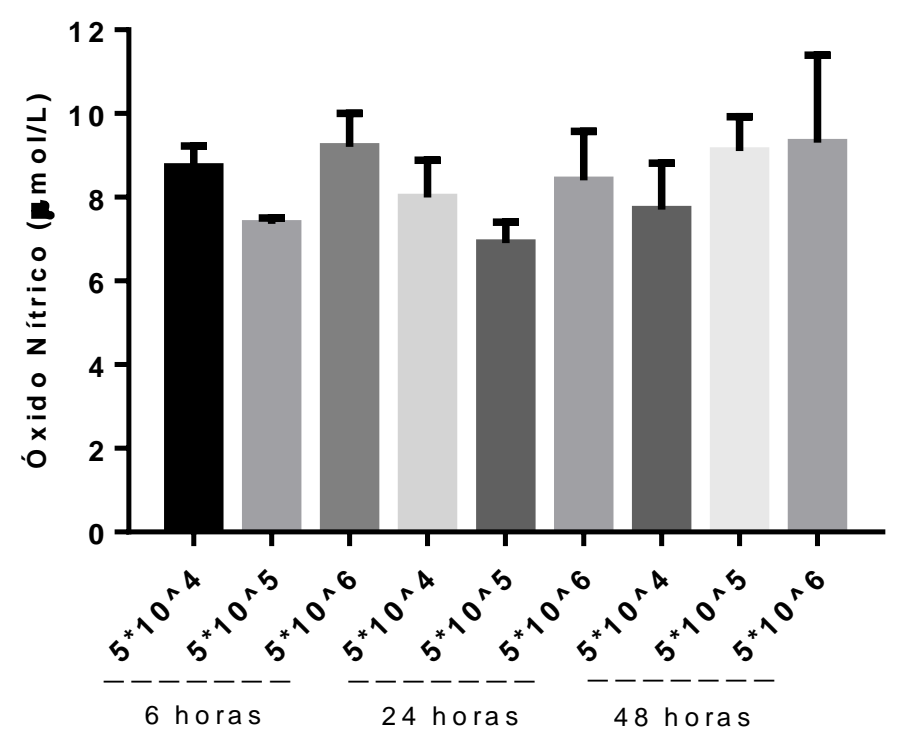

Figura 4 - Produção de óxido nítrico no sobrenadante de células J774A.1 em diversas concentrações celulares e em tempos de 6, 24 e 48 horas

Os resultados de NO foram expressos em $\mu \mathrm{mol} / \mathrm{L}$ e representam a média \pm de três experimentos independentes 
5.2 Ensaios para avaliação da viabilidade celular após interação com os extratos de plantas

\subsubsection{Ensaio utilizando como reagente WST-8}

\subsubsection{Interação dos extratos das plantas com o reagente WST-8}

Os extratos de Pouteria torta e Pouteria ramiflora foram testados em diferentes concentrações de forma inicial. As concentrações escolhidas foram as de 5, 2,5, 1,25, 0,625, 0,313, 0,156, 0,078, 0,039 e 0,020 mg/mL. Antes de serem testados com as células J774A.1, foi necessário testar se havia algum tipo de interação química entre os extratos em suas diversas concentrações e o reagente WST-8 (Cell Counting kit-8) o que levaria a falsos resultados no ensaio de citotoxicidade.

Durante o ensaio realizado foi considerado que não houve interação entre os extratos e o reagente quando a absorbância (Densidade Ótica em filtro de $450 \mathrm{~nm}$ ) foi inferior ou igual ao branco, que era apenas poços contendo o reagente WST-8. Foi obtido, durante o experimento, uma absorbância de 0,110 para o Branco, e as concentrações dos extratos que não apresentaram interferência em relação ao reagente foram as de $0,020,0,039$ e $0,078 \mathrm{mg} / \mathrm{mL}$ para os três extratos vegetais testados, e para padronização nos experimentos posteriores essas foram as concentrações utilizadas, mesmo levando em conta que ambos os extratos de Pouteria ramiflora (PR Aq e Pr Et) também não apresentaram interação na concentração de 0,156 $\mathrm{mg} / \mathrm{mL}$ (Figura 5). 


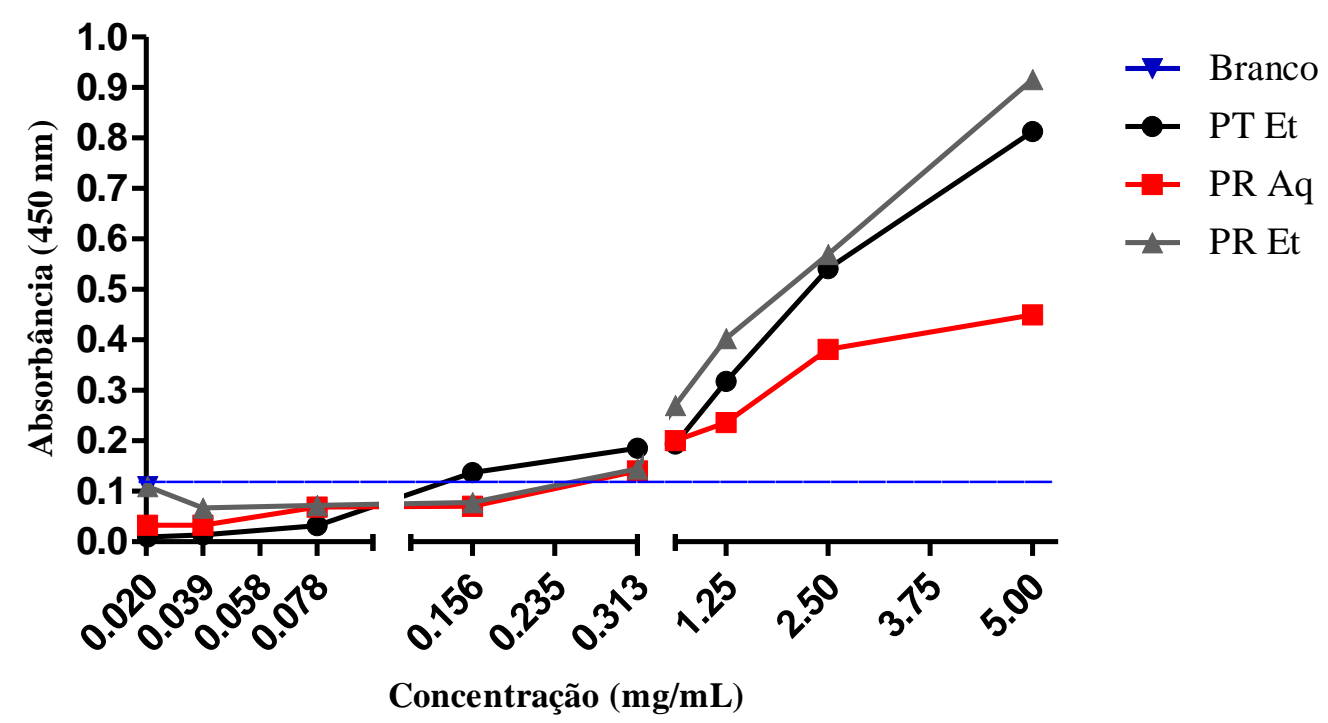

Figura 5 - Análise da interação química entre os extratos de Pouteria torta (PT Et) e Pouteria ramiflora (PR Aq e PR Et) nas diferentes concentrações utilizadas e o reagente de WST-8 (Cell Counting kit-8). Os resultados foram expressos pela média \pm DP das triplicadas de três experimentos independentes

\subsubsection{Efeito dos extratos das plantas sobre a viabilidade celular de J774A.1 pelo método de WST-8}

Uma vez determinado que as concentrações dos extratos que apresentavam interação química com o reagente por meio do experimento anterior, foi dado prosseguimento aos experimentos, agora com a finalidade de avaliar se os extratos de Pouteria spp. apresentariam ação tóxica sobre as células J774A.1, o que influenciaria os resultados posteriores. Foram realizados diversos ensaios utilizando as concentrações padronizadas de 0,020, 0,039 e 0,078 $\mathrm{mg} / \mathrm{mL}$, que seguindo o ensaio anterior não apresentaram interação com o reagente. Em todas as concentrações testadas dos extratos, a viabilidade celular encontrada foi próxima ou superior a $100 \%$, como apresentado na figura 6 . 


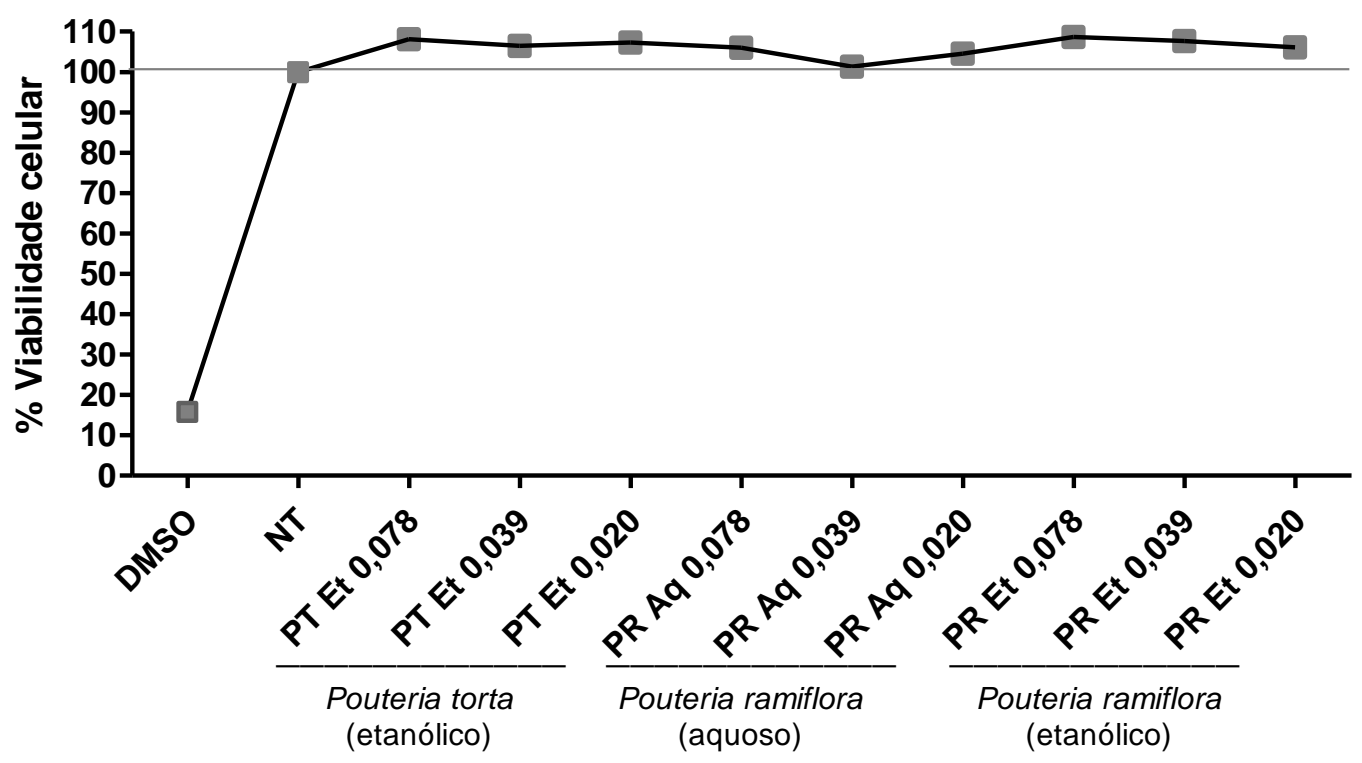

Figura 6 - Efeitos dos extratos de Pouteria torta (PT Et) e Pouteria ramiflora (PR Aq e PR Et) sobre a viabilidade celular de células J774A.1 nas concentrações onde não existe interação química com o reagente WST-8

Os resultados foram expressos como média \pm DP da porcentagem de células viáveis em quatro experimentos independentes. A viabilidade celular foi apresentada graficamente comparada como uma porcentagem do controle positivo (células sem qualquer tratamento que foram consideradas $100 \%$ viáveis)

\subsubsection{Ensaio utilizando como reagente Vermelho Neutro}

\subsubsection{Interação dos extratos das plantas com o reagente Vermelho Neutro}

Como forma de confirmar os resultados obtidos no experimento anterior, avaliando então o efeito citotóxico dos extratos de planta utilizados, foi também realizado o teste de incorporação do vermelho neutro, que assim como o WST-8 avalia viabilidade celular. Novamente foi necessário avaliar se havia interação entre os extratos com o reagente vermelho neutro para posteriormente utilizado para avaliar o efeito citotóxico extratos sobre as células J774A.1. Nesse ensaio, assim como o anterior, foi considerado que não existia interação química quando a absorbância estava abaixo daquela observada no branco. Analisando o ensaio realizado, foi possível concluir que não houve interação química entre o corante utilizado e nenhuma das concentrações dos três extratos vegetais testadas, todas foram inferiores ao branco, que teve absorbância de 0,5 (D.O, em filtro de $492 \mathrm{~nm}$ ), como mostrado na figura 7. 


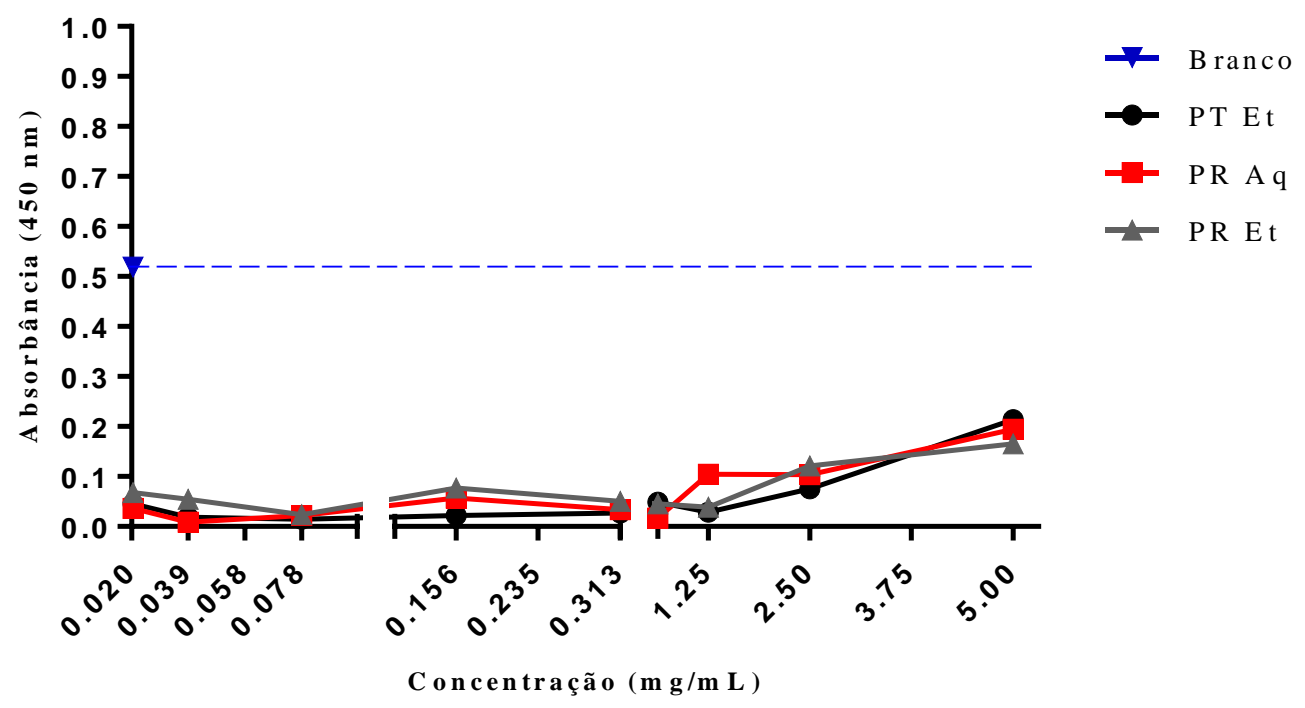

Figura 7 - Interação química entre os extratos de Pouteria torta (PT Et) e Pouteria ramiflora (PR Aq e PR Et) nas diferentes concentrações utilizadas e o reagente vermelho neutro

Os resultados foram expressos como média \pm DP das triplicadas de três experimento independentes

\subsubsection{Efeito dos extratos sobre a viabilidade celular de J774A.1 pelo método de Vermelho Neutro}

Como forma de confirmar se os extratos de Pouteria spp. apresentam ou não atividade tóxica para as células, essas foram então testadas utilizando método de incorporação do vermelho neutro, utilizando as concentrações padronizadas com a outra metodologia para confirmar o resultado obtido no ensaio utilizando o método WST-8.

Além das concentrações padronizadas pelo método WST-8, as diluições de 5, 2,5, 1,25, $0,625,0,313$ e $0,156 \mathrm{mg} / \mathrm{mL}$ foram testadas com o objetivo de avaliar atividade citotóxica. Nas concentrações de 1,25, 2,5 e $5 \mathrm{mg} / \mathrm{mL}$ houve redução considerável na viabilidade celular (dado não apresentado), enquanto nas concentrações de 0,078, 0,039 e 0,020 mg/mL, a viabilidade mais uma vez se encontrou próxima de $100 \%$.

Com base nos resultados de viabilidade celular e citotoxicidade, as concentrações dos extratos que apresentaram efeito tóxico para as células foram então excluídas, além daquelas que tiveram interação química com os reagentes, dessa forma padronizando as concentrações de $0,078,0,039$ e $0,020 \mathrm{mg} / \mathrm{mL}$ dos extratos PT Et, PR Aq e PR Et no tempo de 48 horas para serem testadas nos próximos ensaios experimentais. 


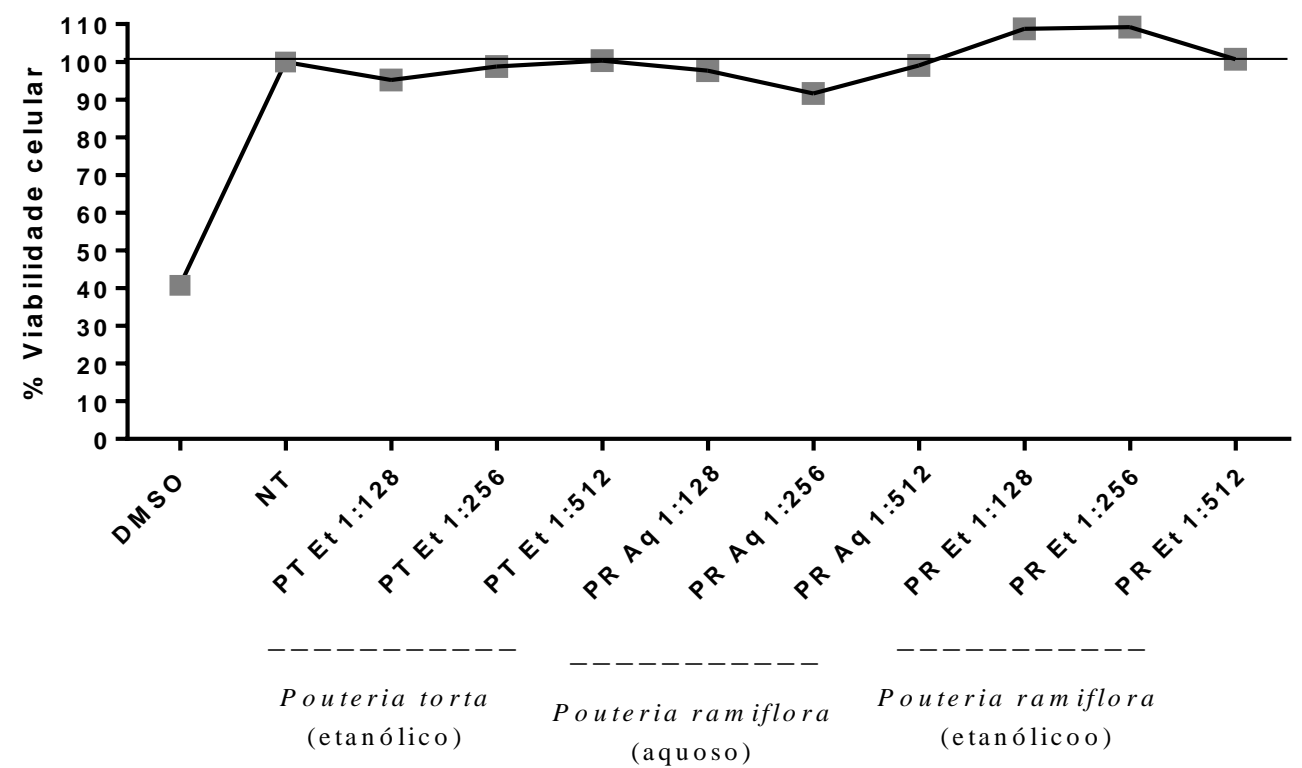

Figura 8 - Efeitos dos extratos de Pouteria torta (PT Et) e Pouteria ramiflora (PR Aq e PR Et) sobre a viabilidade celular das células J774A.1 com base no método de incorporação do vermelho neutro Os resultados foram expressos como média \pm DP da porcentagem de células viáveis em três experimentos independentes. A viabilidade celular foi apresentada graficamente comparada como uma porcentagem do controle positivo (células sem qualquer tratamento que foram consideradas $100 \%$ viáveis) 


\subsection{Expressão gênica}

\subsubsection{Quantificação relativa dos transcritos dos genes NFkb, Tnf- $\alpha$, IL-6, iNOS e COX- 2 após tratamento com extrato etanólico de Pouteria torta (PT Et)}

Ao analisar a quantificação relativas dos transcritos dos cinco genes abordados durante o estudo após o tratamento com o extrato PT Et nas concentrações padronizadas foi possível verificar, de forma geral, uma redução no número de transcritos de todos os genes em relação ao grupo tratado com LPS.

Quando comparado com o grupo calibrador 2 (LPS/Extrato PT Et) em cada um dos genes estudados, foi observado que quando a concentração do extrato igual a 0,078 mg/mL, houve uma redução de 519 vezes na expressão do $N F \kappa B$ em relação ao grupo controle LPS, além de reduções de 27567,2 vezes na expressão do $I L-6,80$ vezes na expressão de $T N F$ - $\alpha$, 1256 vezes na expressão de $i N O S$ e de 1182 vezes na expressão de $C O X-2$.

Na concentração de $0,039 \mathrm{mg} / \mathrm{mL}$, em relação ao grupo calibrador 2 (LPS/PT Et 2), foi verificada uma redução de 145 vezes na expressão do gene $N F \kappa B$, redução de 2917,5 vezes na expressão de $I L-6$, redução de 38 vezes na expressão de $T N F$ - $\alpha$, redução de 265 vezes na expressão de $i N O S$ e por fim redução de 329 vezes para o gene $C O X-2$.

Para a concentração de maior diluição, $0,020 \mathrm{mg} / \mathrm{mL}$, houve uma menor redução na expressão do número de transcritos dos genes analisados, como era esperado com base nos dados produzidos por Teotônio (2015). No tratamento com essa diluição houve redução de 90 vezes na produção de transcritos do $N F \kappa B$, redução de 1488,9 vezes na expressão de $I L-6$, redução de 31 vezes na expressão de $T N F$ - $\alpha$, redução de 175 vezes na expressão de $i N O S$ e de 138 vezes na expressão de $C O X-2$. Tal redução pode ser observada ao verificar a figura 9.

De maneira geral, as concentrações de menor diluição apresentaram maior desempenho na redução do processo inflamatório induzido pelo LPS. 

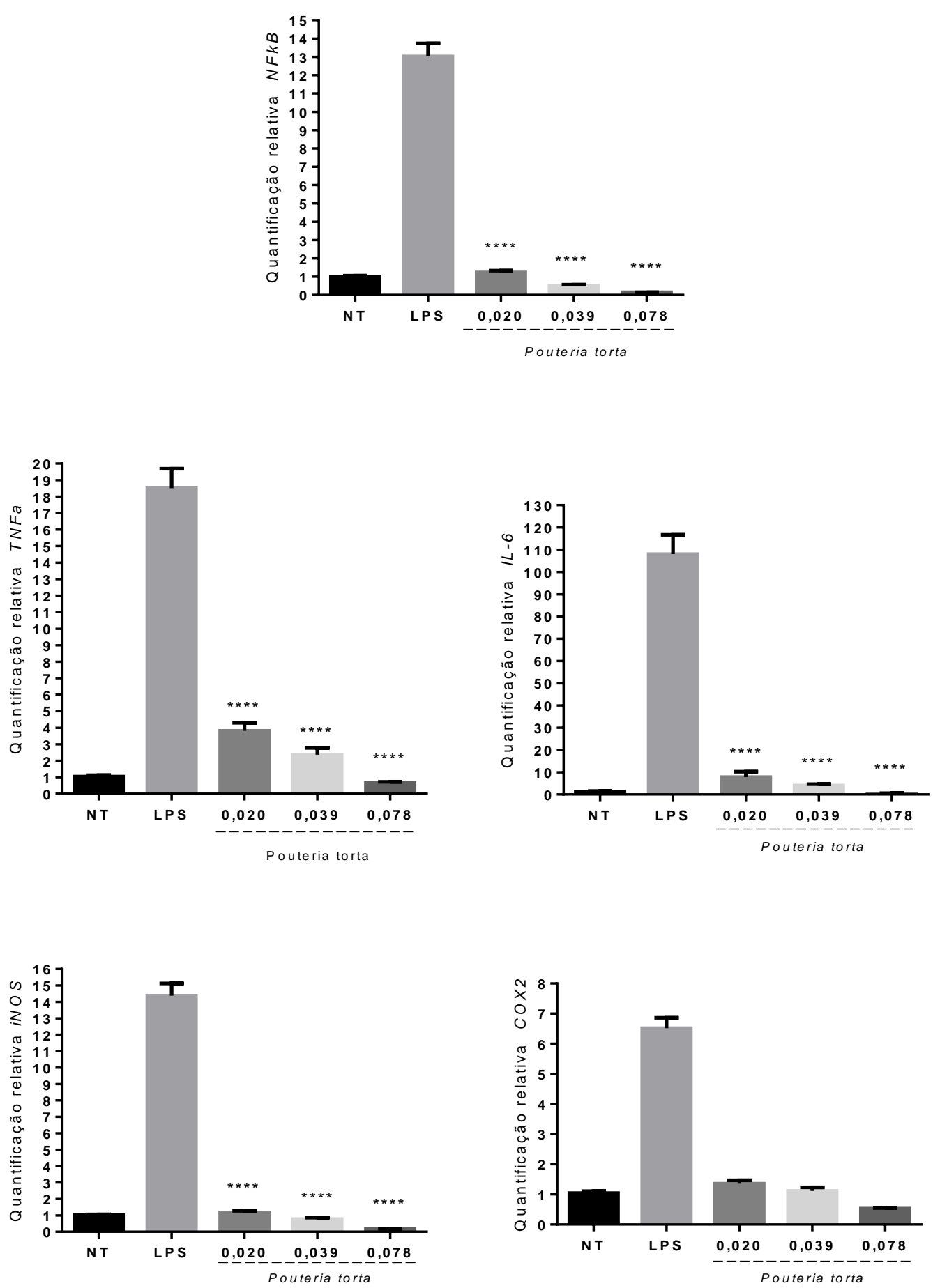

Figura 9 - Expressão gênica de células J774A.1 48 horas após tratamento com extratos de Pouteria torta (PT Et) nas concentrações de 0,020, 0,039 e $0,078 \mathrm{mg} / \mathrm{mL}$

Análise estatística ANOVA de duas vias com pós-teste de Bonferroni de múltipla comparação, os resultados de Quantificação Relativa em comparação com o LPS revelaram **** $p<0.001$ 


\subsubsection{Quantificação relativa dos transcritos dos genes NFkb, Tnfa, IL-6, iNOS e Cox- 2 após tratamento com extrato aquoso de Pouteria ramiflora (PR Aq)}

Ao realizar a análise da quantificação relativa dos transcritos dos genes de interesse no estudo após tratamento com o extrato PR Aq nas concentrações padronizadas pode ser observado, mais uma vez, redução no nível de expressão dos cinco genes avaliados, indicando diminuição no número de transcritos dos genes ligados ao processo inflamatório, um indicativo de atividade anti-inflamatória do extrato (Figura 10).

De forma inesperada, quando comparamos o grupo calibrador 2 (LPS/PR Aq 2) tratado com o extrato na concentração de $0,039 \mathrm{mg} / \mathrm{mL}$ para todos os genes, foi aquele que apresentou maior redução no número de transcritos gênicos. Nesse grupo foi constatado uma redução no número de transcritos de $N F \kappa B$ de 267 vezes, seguido de uma redução de 9255,4 vezes na expressão dos transcritos de $I L-6$, redução de 86 vezes para $T N F$ - $\alpha$, redução de 1490 vezes para iNOS e finalmente redução de 990 vezes na expressão de transcritos do gene $C O X-2$.

A concentração mais diluída, $0,020 \mathrm{mg} / \mathrm{mL}$, mais uma vez de forma inesperada, foi a segunda a apresentar maior nível de diminuição na expressão no número de transcritos gênicos, que mesmo menor que a apresentada pelos grupos LPS/PR Aq 2 ainda permanece significativa. Houve redução na ordem de 220 vezes na expressão dos transcritos do gene $N F \kappa B$, redução de 6098,1 vezes na expressão de transcritos de $I L-6$, redução de 49 vezes na expressão de transcritos de $T N F$ - $\alpha$, redução de 564 vezes na expressão de transcritos de $i N O S$ e por fim redução de 460 vezes na produção dos transcritos do gene COX-2.

Por fim o grupo LPS/PR Aq 1 foi aquele que apresentou menor redução na expressão gênica em todos os genes estudados, ainda que tal redução tenha sido extremamente significativa. Nesses grupos, onde houve o tratamento com o extrato a concentração de 0,078 $\mathrm{mg} / \mathrm{mL}$, foram verificadas reduções na expressão gênica na ordem de 120 vezes no gene $N F \kappa B$, 1758,2 vezes nos transcritos do gene $I L-6,27$ vezes nos transcritos do gene $T N F-\alpha, 172$ vezes para transcritos do gene $i N O S$ e por fim de 147 vezes para $C O X-2$. 

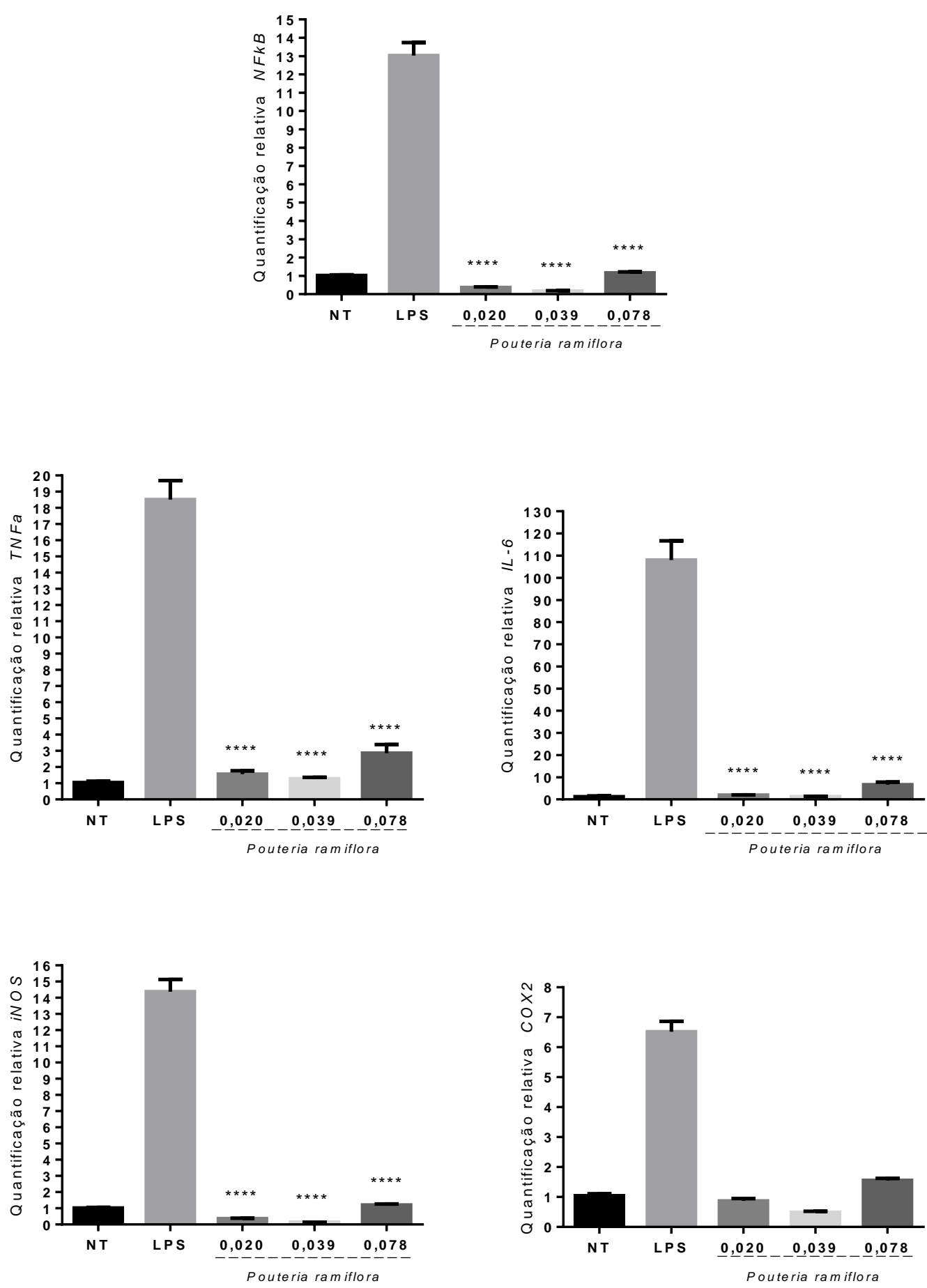

Figura 10 - Expressão gênica de células J774A.1 48 horas após tratamento com extratos de Pouteria ramiflora (PT Aq) nas concentrações de $0,020,0,039$ e $0,078 \mathrm{mg} / \mathrm{mL}$

Análise estatística ANOVA de duas vias com pós-teste de Bonferroni de múltipla comparação, os resultados de Quantificação Relativa em comparação com o LPS revelaram ****p $<0.001$ 


\subsubsection{Quantificação relativa dos transcritos dos genes NFkb, Tnfa, IL-6, iNOS e Cox-}

2 após tratamento com extrato etanólico de Pouteria ramiflora (PR Et)

Com base na quantificação relativa dos produtos da transcrição dos genes analisados após o tratamento com as diluições do extrato PR Et mais uma vez foi possível verificar significante redução no nível de expressão de transcritos dos genes em questão, sendo que a repressão do gene IL-6 foi a mais significativa entre os três extratos de plantas utilizados.

Dentre as concentrações dos extratos testados, aquele que monstrou maior redução em relação ao grupo calibrador 2 (LPS/PR Et 1). Para todos os genes avaliados, o grupo tratado com o extrato diluído a $0,078 \mathrm{mg} / \mathrm{mL}$, a redução no número de transcritos dos genes estudados na ordem de 694,3 vezes para o $N F \kappa B$, redução de 19.448.677 vezes para os transcritos do gene IL-6 (maior redução observada no presente estudo), redução de 67 vezes para $T N F-\alpha$, redução de 1269 vezes para o iNOS e redução de 1060 vezes para produção de COX-2 (Figura 11).

Como o esperado ao aumentar a diluição do extrato, que estava na concentração de $0,039 \mathrm{mg} / \mathrm{mL}$, houve redução na expressão do número de transcritos dos genes $N F \kappa B, I L-6$, TNF- $\alpha, i N O S$ e $C O X-2$ em 336, 22862,9, 54, 685 e 627 vezes, respectivamente.

Como esperado, o grupo com maior diluição do extrato utilizado foi aquele que apresentou menor capacidade de repressão no número de transcritos dos genes estudados. Esse grupo, LPS/PR Et 3, grupo que recebeu o tratamento com o extrato na concentração de 0,020 $\mathrm{mg} / \mathrm{mL}$, reduziu a expressão no número de transcritos do gene $N F \kappa B$ em 112 vezes, reduziu a expressão do gene $I L-6$ em 3874,1 vezes, reduziu a expressão do gene $T N F$ - $\alpha$ em 20 vezes, reduziu a expressão do gene $i N O S$ em 98 vezes e por fim reduziu a expressão do gene $C O X-2$ em 207 vezes. 

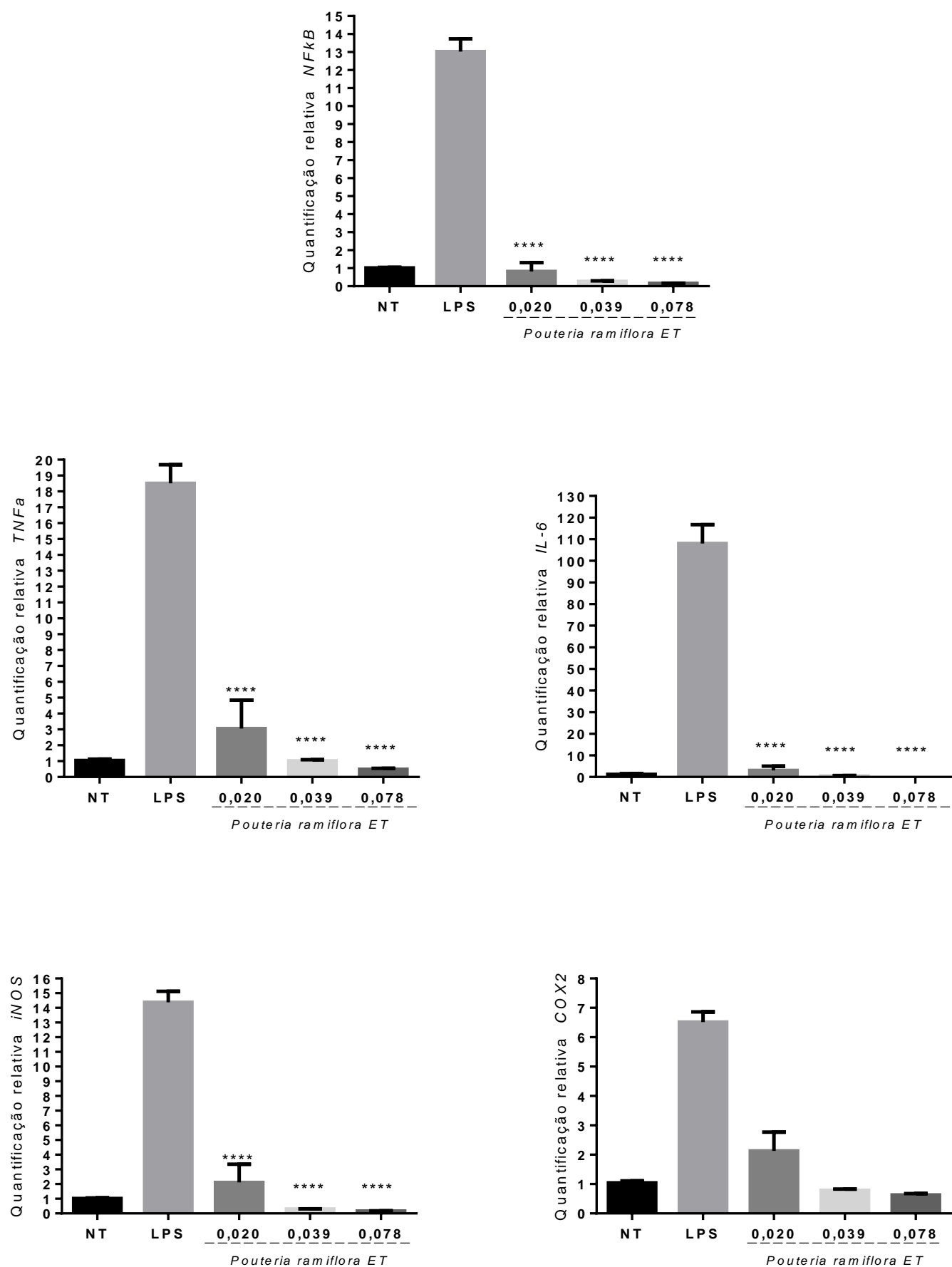

Figura 11 - Expressão gênica de células J774A.1 48 horas após tratamento com extratos de Pouteria ramiflora (PT Et) nas concentrações de 0,020,0,039 e 0,078 mg/mL

Análise estatística ANOVA de duas vias com pós-teste de Bonferroni de múltipla comparação, os resultados de Quantificação Relativa em comparação com o LPS revelaram ****p $<0.001$ 


\section{$5.4 \quad$ Dosagem de Óxido Nítrico}

Com a finalidade de mensurar os efeitos dos diferentes extratos na produção de Óxido Nítrico (NO), foi realizada a medição indireta desse metabólito pela mensuração da quantidade de nitrito $\left(\mathrm{NO}^{2-}\right)$ utilizando o consagrado método de Griess.

Os resultados são apresentados abaixo na Figura 12, que evidencia a redução, em certos casos maior do que em outros, a produção do óxido nítrico em todos os tratamentos, principalmente nas concentrações mais baixas testadas.

O extrato PT Et foi capaz de produzir uma redução menos significativa da produção de óxido nítrico quando comparado com os demais extratos, sendo mais eficaz na concentração de $0,020 \mathrm{mg} / \mathrm{mL}$, para as demais concentrações também foram capazes de produzir redução na produção de NO, mesmo que em menor quantidade, dado compatível com o gerado pela redução no número de transcritos na expressão gênica, que indica que a concentração de 0,078 $\mathrm{mg} / \mathrm{mL}$ é aquela com a maior capacidade de redução de expressão gênica.

$\mathrm{O}$ extrato PR Aq apresentou uma maior redução na produção de óxido nítrico em relação ao PT Et em todas as concentrações testadas, sendo que a concentração $0,039 \mathrm{mg} / \mathrm{mL}$ testada foi aquela que apresentou maior redução na produção de NO.

E por fim, o extrato PR Et também foi capaz de inibir a produção de NO de forma mais eficiente do que o PT Et, sendo que a concentração de $0,078 \mathrm{mg} / \mathrm{mL}$ testada, apresentou uma maior redução do que nas demais (Figura 12).

De maneira geral os extratos monstraram possuir uma atividade anti-inflamatória sobre as células da linhagem J774A.1, equivalente à mesma proporção que seria esperada com base nos dados gerados de expressão gênica, como será discutido na análise completa desses dados em conjunto com os dados de expressão do gene iNOS. 


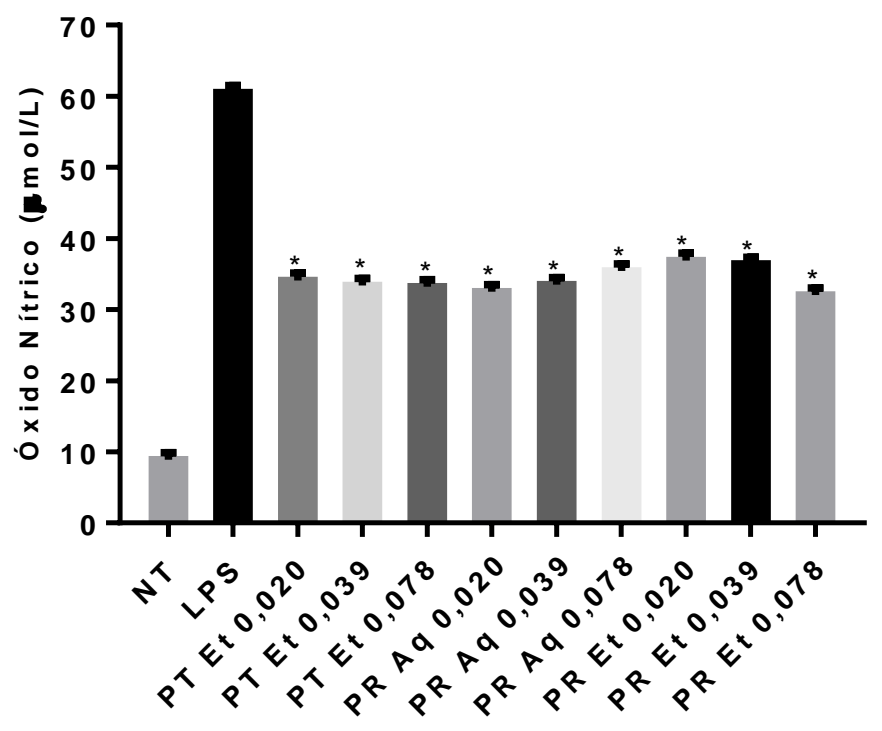

Figura 12 - Nível de produção de óxido nítrico no sobrenadante de células da linhagem J774A.1 após 48 horas de tratamento com os extratos PT Et, PR Aq e PR Et nas concentrações padronizadas $(0,078$, $0,039,0,020 \mathrm{mg} / \mathrm{mL}$ ) e estimulados com $1 \mu \mathrm{g} / \mathrm{mL}$ de LPS.

Análise estatística ANOVA de uma via com pós-teste de Dunn de múltipla comparação, os resultados de NO em comparação com o LPS revelaram * $p<0.001$ 


\section{DISCUSSÃO}

Doenças crônico inflamatórias são importantes causas de morbidade e prejuízos nos ambientes sociais e de trabalho, sendo responsável pela morte de cerca de 35 a 52 milhões de pessoas todos os anos ao redor do planeta, sendo que pequenos processos inflamatórios contínuos podem ser considerados a grande causa da maior parte dessas enfermidades (PRUIMBOOM; RAISON; MUSKIET, 2015).

Com isso em mente, diversos pesquisadores têm abordado linhas de pesquisa voltadas para desenvolvimento de fármacos anti-inflamatórios que não apresentem os efeitos colaterais derivados do uso dos fármacos convencionais, como gastrite severa, úlcera, náusea, entre outros, de forma a tratar ou mesmo prevenir os sintomas ligados a diversas doenças inflamatórias. Como medicamentos com base em plantas não apresentam tais efeitos danosos existe uma tendência natural a condução de investigações para a produção de medicamentos baseados em plantas (ALOLGA et al., 2015).

O levantamento de informações etnofarmacológicas ganha um destaque ainda maior nesse cenário, o que possibilitaria identificação de vários produtos naturais usualmente utilizados como fármacos, importantes candidatos para produção de fármacos com menos efeitos negativos mantendo a eficiência encontrada em drogas sintéticas. De fato, diversos estudos tem sido bem-sucedidos no isolamento de compostos com atividade biológica de interesse para diversos campos, inclusive como agentes anti-inflamatórios que poderiam ser usados para tratar diversas patologias (FERREIRA et al., 2013; KIM; PARK; KIM, 2013; NGUTA et al., 2016).

O presente estudo teve como objetivo investigar os efeitos anti-inflamatório e protetor de extratos de duas espécies do gênero Pouteria, Pouteria torta e Pouteria ramiflora. Ambos os extratos foram produzidos a partir da maceração de folhas de ambas as espécies, sendo que foi produzido apenas extrato etanólico para a primeira espécie e para a segunda foi também preparado extrato aquoso e etanólico. Macrófagos foram escolhidas como as células ideais para realização do estudo, uma vez que essas células são fontes de muitas citocinas diretamente ligadas ao processo inflamatório, e por isso as células da linhagem J774A.1 foram escolhidas, devido a sua alta resposta a tais estímulos (CHEN et al., 2012; SCOTECE et al., 2012).

O lipopolissacarídeo, componente da parede celular de bactérias gram-negativas (LPS), foi utilizado para estimular a resposta inflamatória das células utilizadas. Ao serem estimulados com LPS, macrófagos simulam a reação esperada durante a resposta inflamatória, produzindo 
fatores pró-inflamatórios tais como NO induzido pela iNOS e com base nisso elementos capazes de inibir a produção ou liberação desse mediador, entre outros, ou que regule a expressão dos genes responsáveis por sua produção ou outros genes inflamatórios como o COX-2, podem ser considerados elementos com atividade anti-inflamatória (JUNG et al., 2009; SHAHBAZI et al., 2016; WONG et al., 2016).

Antes de dar-se início aos experimentos para verificar se a hipótese de que os extratos possuem efeitos anti-inflamatório e protetor em células da linhagem J774A.1 foi preciso determinar a melhor concentração de LPS para uma reação inflamatória das células. A concentração escolhida para produção dos mediadores inflamatórios foi $1 \mu \mathrm{g} / \mathrm{mL}$ no tempo de 48 horas, seguindo diversos trabalhos na literatura que sugerem que esta seria a melhor concentração para o estudo, além de possibilitar a discussão dos resultados com outro trabalho produzido pela equipe de pesquisa (BANJANAC et al., 2012; D’AGOSTINO et al., 2001b; MUNIĆ et al., 2011).

A produção de NO e expressão gênica pode ser influenciada pela quantidade de células utilizadas em cada experimento, portanto foi fundamental a realização de um ensaio para verificar qual seria a concentração ideal para realizar os experimentos, levanto em conta o tempo do estímulo, que também poderia influenciar os resultados. Por meio dos ensaios realizados foi possível verificar que a produção de NO não variava de forma significativa dependendo da quantidade de células ou tempo de estímulo, portanto foi escolhido a concentração onde houve maior produção do mediador inflamatório, excluindo o tempo de 72 horas foi nesse tempo as células tornavam-se inviáveis.

Exames pré-clínicos são vitais para assegurar a eliminação de componentes inadequados para testes in vivo, de forma a reduzir testes ineficazes em animais e em humanos. Técnicas de testes in vitro como exame inicial na avaliação de potenciais compostos farmacêuticos tornavam-se padrão no meio cientifico pois é possível a seleção de células que simulem doenças específicas ou anormalidades. Testes in vitro são de grande importância por avaliar, além de possíveis efeitos positivos, efeitos de perfil tóxico desses compostos. Para tal, testes que avaliem efeito citotóxico desses compostos tornam-se essenciais para avaliar fármacos em desenvolvimento (ALLEN et al., 2005; VAN TONDER; JOUBERT; CROMARTY, 2015).

Com o objetivo de avaliar o potencial citotóxico dos extratos que foram utilizados durante o estudo, dois métodos colorimétricos foram empregados para determinar a viabilidade celular após tratamento com tais extratos em diferentes concentrações, de forma a eliminar 
aquelas que levavam a perda de viabilidade ao buscar as concentrações com melhor atividade biológica.

Os dois ensaios empregados no estudo foram o método WST-8 e o ensaio de incorporação de vermelho neutro. O método WST-8 é um dos vários ensaios criados a partir do MTT (brometo de 3-(4,5-dimetiltiazol-2-ila)-2,5-difeniltetrazolium), método que mede redução do tetrazolium em cristais insolúveis em organelas de células viáveis, padrão-ouro para testes de viabilidade e proliferação celular desde seu desenvolvimento por Mosmann durante a década de 1980.

O ensaio de incorporação do vermelho neutro foi realizado de forma a confirmar os resultados obtidos com o método WST-8. Esse ensaio foi desenvolvido na Universidade Rockefeller e baseia-se na incorporação do corante vermelho neutro realizada por lissosomos de células viáveis, sendo um método com alta sensibilidade para detecção de viabilidade celular (AKREMI et al., 2016; REPETTO; DEL PESO; ZURITA, 2008).

$\mathrm{Na}$ literatura ainda é escasso o número de artigos que demostram atividades biológicas nas espécies Pouteria torta e Pouteria ramiflora, mesmo que alguns estudos recentes tenham começado a abordar modelos clínicos para demostrar tais efeitos. O estudo de Napolitano et al. (2005) examinou o efeito de extratos hexânicos e etanólicos das folhas de exemplares de Pouteria ramiflora, de forma semelhante à realizada nesse trabalho, em macrófagos J774A.1 estimulados com LPS (10 $\mu \mathrm{g} / \mathrm{mL})$ e IFN- $\gamma$. O referido estudo chegou na conclusão que, mesmo não apresentando citotoxicidade ao ser avaliado por meio de MTT, os extratos não eram capazes de reduzir a produção de Óxido Nítrico, ao contrário do verificado no presente estudo e também demostrado por Teotônio (2015) em macrófagos RAW 264.7.

Souza et al. (2012) trabalharam com a atividade inibitória da tirosinase dos extratos aquoso, etanólico e hexánico de folhas e outros fragmentos de Pouteria torta e Pouteria ramiflora, dentre outras espécies vegetais, e verificaram por meio de ensaio de MTT realizado em células da linhagem HeLa que ambos os extratos não apresentavam efeitos citotóxicos, além de serem eficazes na inibição da enzima estudada, em especial o extrato etanólico das folhas de $P$. torta (SOUZA et al., 2012).

Os extratos hexânico, etanólico e aquoso de folhas dessas duas espécies mostraram toxicidade quando testados em larvas de Artemia salina na concentração de $0,28 \mathrm{mg} / \mathrm{mL}$, uma fração muito superior a aquelas utilizadas durante o presente estudo (PERFEITO, 2005).

Ainda sobre a avaliação de citotoxicidade, Elias et al. (2013) testaram a atividade citotóxica dos extratos etanólico, aquoso e hexânico de folhas de $P$. torta nas concentrações de $0,1,0,75,0,5,0,25$ e $0,125 \mathrm{mg} / \mathrm{mL}$ com a finalidade de induzir morte celular em linhagens de 
células humanas cancerígenas, especificamente tumores orais e de mama. Em ambos os casos foi demostrado efeito citotóxico para as células estudadas, evidenciando o potencial para combate desses tipos de câncer, mais uma vez destacando a relevância biológica do cerrado brasileiro como fonte de moléculas bioativas (ELIAS et al., 2013).

Correia et al. (2016) trabalharam com o potencial antifúngico de extratos de Pouteria torta e Pouteria ramiflora, avaliando a ação desses extratos sobre o crescimento de culturas de Candida albicans e outras espécies de fungo do gênero Candida. Nesse estudo foi demostrado que ambos os extratos possuem tal atividade, e os extratos de Pouteria ramiflora demonstram uma ação ainda mais eficaz contra espécies não albicans, mais uma vez demonstrando o potencial dessas espécies de plantas (CORREIA et al., 2016).

Além disso, Fonte-Junior (2009) avaliou o efeito extrato etanólico de raízes de Pouteria ramiflora sobre camundongos e ratos para verificar atividade antinociceptiva e antiinflamatória. O extrato não demonstrou toxicidade, além de apresentar bons resultados para ambas atividades, diminuindo contorções abdominais e, assim como demonstrado nesse estudo e no estudo de Teotônio (2015), redução na produção de NO.

Nesse estudo foi demonstrado que a produção de óxido nítrico aumenta de forma considerável em células estimuladas com LPS, que atuam como controle positivo, quando comparadas com aquelas não tratadas, controle negativo. Diversos outros estudos corroboram com tal resultado (AMANO; NODA, 1995; D’AGOSTINO et al., 2001b; KIM et al., 2007; PARK et al., 2016; PUNTUREE; WILD; VINITKETKUMNEUN, 2004). Ficou demonstrado que os extratos foram capazes de reduzir a produção de óxido nítrico em relação as células tratadas com LPS e mesmo com aquelas não tratadas.

Além de afetar a produção de NO, os extratos também demonstraram efeito inibitório em relação aos genes abordados durante o estudo quando comparadas as células tratadas com LPS e aquelas não tratadas para a expressão de mRNA transcritos dos genes iNOS, $C O X-2, N F \kappa B, I L-6$ e $T N F-\alpha$.

Todos os extratos testados, PT Et, PR Aq e PR Et, foram capazes de reduzir a expressão de transcritos dos genes estudados em todas as concentrações utilizadas $(0,078,0,039$ e $0,020 \mathrm{mg} / \mathrm{mL})$ quando comparados com o controle positivo, o que está parcialmente de acordo com a literatura, considerando que Teotônio (2015) também demonstrou redução no nível de expressão para esses extratos, com exceção do extrato PR Et, que naquele estudo demonstrou efeito inibidor dependendo da concentração utilizada.

Variações no efeito desses extratos dependendo da dose utilizada não é algo de todo inesperado, uma vez que os extratos estudados são fitocomplexos, compostos por diversos 
metabólitos primários e/ou secundários das plantas que os deram origem. Eles são responsáveis, em conjunto, pelo efeito biológico de uma planta medicinal ou seus derivados, e a medida que diluímos esses extratos alteramos o efeito de diversos metabólitos sobre as células, o que pode explicar a modulação inesperada observada no extrato PR Aq (BRASIL, 2014b).

Esse efeito variável pode ser associado com a concentração de fitocompostos em relação ao alvo, criando uma variação semelhante ao chamado efeito prozona. O efeito prozona é um fenômeno imunológico onde existe um desequilíbrio entre a quantidade de antígeno e anticorpo na reação de aglutinação, sendo possível casos onde o excesso de anticorpo provoque um desequilíbrio na ligação, diminuindo a eficiência, para citar uma das explicações possíveis (JACOBS et al., 2015).

Dentro da literatura existem casos relatados de eventos similares, como um teste para efeito protetor de Ig polivalente humano em camundongos neutropênicos NALN/c infectados com Streptococcus pneumoniae. Doses de 50 e $100 \mathrm{~g} /$ camundongo foram eficazes, enquanto doses de 250 e $500 \mathrm{~g} /$ camundongo não apresentaram o mesmo efeito. Além desse exemplo também foi encontrado na literatura um trabalho comparando a eficácia citotóxica de anticorpos biespecíficos anti-CD7 e anti-CD38 conjugados com Proteínas Ribossomais Inativadas derivadas de plantas (RIP) ligadas a saponinas, formando a imunotoxina RIP-saporina. Nesse experimento houve efeito prozona em concentrações acima de $0,1 \mathrm{nM}$ da imunotoxina, sendo invertido pelo aumento da concentração de saporina no sistema (FLAVELL, 1995; TABORDA et al., 2003).

É possível imaginar que um efeito semelhante aconteça com os extratos utilizados à medida que estão sendo diluídos, as diversas moléculas bioativas presentes entrando em equilíbrio ao variar sua concentração, chegando a um equilíbrio semelhante ao observado na chamada de zona de equivalência de Heidelberger-Kendall observada no efeito prozona clássico. Resultados semelhantes foram observados por Teotônio (2015).

Fitocomplexos são substâncias formadas por diversos compostos bioativos e não necessariamente aqueles de interesse para produção farmacológica são aqueles presentes em maior quantidade. Por esse motivo, é essencial a análise posterior de qualquer extrato candidato a medicamento para se analisar qual fração do extrato apresenta tal atividade, sendo metodologias como a Cromatografia Líquida de Alta Performance (HPLC da sigla em inglês) uma ferramenta útil para investigação (DONNO et al., 2016; FILHO; YUNES, 1998).

Quando comparamos a produção de transcritos na expressão gênica podemos afirmar que os três extratos testados apresentam um nível de inibição de produção de mRNA de certa forma semelhante, sendo que o extrato PR Et destoa dos outros em relação a seu nível de repressão do gene $I L-6$. O extrato $\mathrm{PR} A q$ é o menos eficaz na inibição da expressão de transcritos do gênicos na maior parte dos genes estudados. 
O mediador inflamatório mais sensível à presença dos extratos foi a $I L-6$, gene que foi fortemente suprimido por todos os extratos, em especial pelo PR Et. A IL-6 é uma citocina com alta atividade pró-inflamatória, sendo um importante indicador de resposta inflamatória (LOKAU; AGTHE; GARBERS, 2016; MUNIĆ et al., 2011).

Várias vias inflamatórias, como a liberação de mediadores inflamatórios como o óxido nítrico e prostaglandinas, expressão de citocinas como o $T N F$ - $\alpha$ e a $I L-6$ são regulados pelo fator de transcrição $N F \kappa B$, gene altamente expresso por macrófagos ativados presentes em diversas doenças inflamatórias e outras situações de desequilíbrio, como doenças crônicas (DEL PRETE, 2011; MARKS-KONCZALIK, J.; CHU, S. C.; MOSS, 1998).

Como é um fator ligado a expressão de diversos genes pró-inflamatórios, é evidente que substâncias que inibam a expressão do $N F \kappa B$ são importantes candidatos a medicamentos anti-inflamatórios (JOUNG et al., 2012; YUAN et al., 2013).

Ainda que em menor intensidade do que genes como o IL-6, os resultados apresentados nesse trabalho demonstram redução na expressão do mRNA do NFkB quando em comparação com o controle positivo, que tem esse gene ativado. Isso por si só já permitiria supor que os extratos estudados apresentam ação anti-inflamatória, o que se torna ainda mais sólido quando em conjunto com os demais resultados. A análise dos resultados leva a crer que os extratos estudados são bons candidatos para tratar doenças inflamatórias, como também concluído por Teotônio (2015).

O nível de expressão dos demais genes inflamatórios analisados nesse estudo ( $C O X-2$, $I L-6, i N O S$ e $T N F-\alpha$ ) possivelmente foram diretamente influenciados pela inibição do $N F \kappa B$, já que esse gene está envolvido na expressão desses fatores.

Mesmo com os dados positivos em relação a expressão gênica, é necessário avaliar a produção de fatores inflamatórios de forma mais direta para poder avaliar o potencial antiinflamatório de uma substância. A análise de produção de NO é um bom alvo para essa finalidade uma vez que compostos que diminuem sua produção são candidatos atraentes como agentes anti-inflamatórios (ELMANN et al., 2011; KIM et al., 2009).

Outras espécies do gênero Pouteria, como a $P$. campechiana e a $P$ lucuma, tiveram ação biológica demonstrada em experimentos, incluindo ação inibitória em relação a produção de NO, demonstrando ação anti-inflamatória (MURAKAMI et al., 2005; ROJO et al., 2014).

O motivo pelo qual os extratos de Pouteria que foram utilizados nesse estudo apresentaram atividade anti-inflamatória e antioxidante como sugerido pelos resultados pode ser derivado da presença de compostos fenólicos, que modulam a via de sinalização MAPK, podem bloquear a produção de $\mathrm{NF \kappa B}$, podem suprimir citocinas e atividade de enzimas 
inflamatórias como a iNOS e COX-2. Em extratos de Pouteria o principal composto fenólico presente são os flavonóides (SILVA; SIMEONI; SILVEIRA, 2009; VERES, 2012).

Os dados presentes nesse estudo, em conjunto com outros trabalhos produzidos pela equipe de pesquisa, indicam atividade anti-inflamatória e antioxidantes dos extratos estudados, sendo necessário estudos complementares para isolar as substâncias responsáveis pelos efeitos relatados (TEOTÔNIO, 2015). 


\section{CONCLUSÃO}

O objetivo do trabalho foi avaliar se os extratos estudados apresentavam atividade protetora e/ou anti-inflamatória e com base nos resultados apresentados durante o estudo é possível inferir que os extratos de Pouteria torta e Pouteria ramiflora, nas concentrações de 0,078, 0,039 e 0,020 mg/mL apresentam tais atividades em célula da linhagem J774A.1. Além de não apresentar toxidade às células estudadas, os extratos possivelmente diminuem o estresse oxidativo nas células uma vez que diminuíram a produção de óxido nítrico.

De forma complementar ao observado em relação a produção de mediadores antiinflamatórios é possível afirmar que, no modelo celular estudado, os extratos possuem, nessas concentrações, a capacidade de modular negativamente a expressão do número de transcritos de genes pró-inflamatórios. Os extratos inibiram a produção de transcritos do fator de transcrição $N F \kappa B$, além dos genes $C O X-2, I L-6$, iNOS e $T N F-\alpha$ no modelo celular com macrófagos J774A.1 estimulados com LPS, o que indica que esses fitocomplexos são possíveis alvos terapêuticos.

Os dados apresentados nesse trabalho são preliminares, ainda necessitando de estudos complementares, entretanto são importantes para ressaltar a importância de estudos de plantas do Cerrado Brasileiro. 


\section{REFERÊNCIAS}

AGARWAL, R. B.; RANGARI, V. D. Antiinflammatory and Antiarthritic Activities of Lupeol and 19A -H Lupeol Isolated From Strobilanthus Callosus and Strobilanthus Ixiocephala Roots. Drugs, v. 35, n. 165206, p. 384-387, 2003.

AKREMI, N. et al. Evaluation of the Genotoxicity and Cytotoxicity of Semipurified Fractions from the Mediterranean Brown Algae, Dictyopteris membranaceaPharmacognosy Magazine India, jul. 2016.

AKTAN, F. iNOS-mediated nitric oxide production and its regulation. Life Sciences, v. 75, n. 6, p. 639-653, 2004.

ALLEN, D. D. et al. Cell lines as in vitro models for drug screening and toxicity studies. Drug development and industrial pharmacy, v. 31, n. 8, p. 757-768, 2005.

ALMEIDA SP, PROENÇA CEB, SANO SM, R. J. Cerrado: espécies vegetais úteis. Planaltina: Embrapa-CPAC. 1998.

ALOLGA, RAPHAEL NAMMAHIME; AMADI, SARAH WAMBUI; ONOJA, VITUS; ASSANHOU, ASSOGBA GABIN; MUYABA, MOSES; KASSIM, S. A. Anti-inflammatory and antipyretic properties of Kang 601 heji, a traditional Chinese oral liquid dosage form. Asian Pacific Journal of Tropical Medicine, v. 8, n. 9, p. 694-700, 2015.

ALVES-ARAUJO, A. Pouteria in Lista de Espécies da Flora do Brasil. Jardim Botânico do Rio de Janeiro, 2016.

AMANO, F.; NODA, T. Improved detection of nitric oxide radical (NO) production in an activated macrophage culture with a radical scavenger, car\{ballot box \}y PTIO, and Griess reagent. FEBS Letters, v. 368, n. 3, p. 425-428, 1995.

ASEERVATHAM, G. S. B. et al. Antioxidant and hepatoprotective potential of Pouteria campechiana on acetaminophen-induced hepatic toxicity in rats. Journal of Physiology and Biochemistry, v. 70, n. 1, p. 1-14, 2014.

BANJANAC, M. et al. Anti-inflammatory mechanism of action of azithromycin in LPSstimulated J774A.1 cells. Pharmacological Research, v. 66, n. 4, p. 357-362, 2012.

BASSO, L. A. et al. The use of biodiversity as source of new chemical entities against defined molecular targets for treatment of malaria, tuberculosis, and T-cell mediated diseases - A Review. Memorias do Instituto Oswaldo Cruz, v. 100, n. 6, p. 475-506, 2005.

BOLETI, A. P. A.; VENTURA, C.A.; JUSTO G.Z. SILVA R. A.; DE SOUZA A. C. T, F. C. V. . Y. T. . M. M. L. R. Pouterin, a novel potential cytotoxic lectin-like protein with apoptosis-inducing activity in tumorigenic mammalian cells. Toxicon, v. 51, p. 1321-1330, 2008.

BOLETI, A. P. D. A. et al. Insecticidal and antifungal activity of a protein from Pouteria torta seeds with lectin-like properties. Journal of Agricultural and Food Chemistry, v. 55, n. 7 , p. 2653-2658, 2007.

BRASIL. PLANO DE AÇÕES ESTRATÉGICAS PARA O ENFRENTAMENTO DAS 
DOENÇAS CRÔNICAS NÃO TRANSMISSÍVEIS (DCNT) NO BRASIL, 2011-2022. [s.l: s.n.]. v. 63

BRASIL. Dispõe sobre o REGISTRO DE MEDICAMENTOS FITOTÉRAPICOS E O REGISTRO E A NOTIFICAÇÃO DE PRODUTOS TRADICIONAIS FITOTERÁPICOS. RDC n $^{\circ} 26$ (13 de Maio de 2014). D.O.U. Brasília: Anvisa, p. 34, 2014 b.

BUCKLEY, C. D. et al. Stromal Cells in Chronic Inflammation and Tertiary Lymphoid Organ Formation. Annu. Rev. Immunol, v. 33, p. 715-45, 2015.

CARAMORI, S. S.; LIMA, C. S.; FERNANDES, K. F. Biochemical characterization of selected plant species from Brazilian Savannas. Brazilian Archives of Biology, v. 47, n. June, p. 253-259, 2004.

CARNEIRO, C.E.; ALVES-ARAUJO, A.; ALMEIDA JR., E.B.; TERRA-ARAUJO, M. . Sapotaceae in Lista de Espécies da Flora do Brasil. Jardim Botânico do Rio de Janeiro, 2016.

CHE, C.; KOIKE K., C. G. A. . F. H. H. S. D. R. H. Triterpenes of Pouteria torta (Sapotaceae). J. Nat Prod. (Lloydia), v. 43, p. 420-421, 1980.

CHEN, J. H. et al. The effects of diketopiperazines from Callyspongia sp. on release of cytokines and chemokines in cultured J774A.1 macrophages. Bioorganic and Medicinal Chemistry Letters, v. 22, n. 9, p. 3177-3180, 2012.

CHOI, Y. Y. et al. The anti-inflammatory potential of Cortex Phellodendron in vivo and in vitro: Down-regulation of NO and iNOS through suppression of NF- $\kappa$ B and MAPK activation. International Immunopharmacology, v. 19, n. 2, p. 214-220, 2014.

CHOVATIYA, R.; MEDZHITOV, R. Review. n. Figure 1, p. 281-288, 2014.

COLEMAN, J. W. W. Nitric oxide in immunity and inflammation. International Immunopharmacology, v. 1, n. 8, p. 1397-1406, 2001.

CORREIA, A. F. et al. Amazonian plant crude extract screening for activity against multidrug-resistant bacteria. European Review for Medical and Pharmacological Sciences, v. 12, n. 6, p. 369-380, 2008.

CORREIA, A. F. et al. Activity of crude extracts from Brazilian cerrado plants against clinically relevant Candida species. BMC Complementary and Alternative Medicine, v. 16, n. 1, p. 203, 2016.

COSTA, A. V. D. ET AL. Neuroprotective effects of Pouteria ramiflora (Mart.) Radlk (Sapotaceae) extract on the brains of rats with streptozotocin-induced diabetes. Metabolic Brain Disease, v. 28, n. 3, p. 411-419, 2013.

COSTA, D. L. M. G. ET AL. Flavonoid Detection in Hydroethanolic Extract of Pouteria torta (Sapotaceae) Leaves by HPLC-DAD and the Determination of Its Mutagenic Activity. Journal of Medicinal Food, v. 17, n. 10, p. 1103-1112, 2014.

CRAGG, G.M.; BOYD, M.R.; GREVER, M.R.; SCHEPARTZ, S. A. Pharmaceutical prospecting and the potential for pharma-ceutical crops - Natural product drug discovery at 
the UnitedStates National Cancer Institute. AnnMissouri Bot Gard, v. 82, p. 47-53, 1995.

D'AGOSTINO, P. et al. Anti-inflammatory effects of chemically modified tetracyclines by the inhibition of nitric oxide and interleukin-12 synthesis in J774 cell line. International Immunopharmacology, v. 1, n. 9-10, p. 1765-1776, $2001 \mathrm{a}$.

D'AGOSTINO, P. et al. Anti-inflammatory effects of chemically modified tetracyclines by the inhibition of nitric oxide and interleukin-2 synthesis in $\mathrm{J} 774$ cell line.

Int.Immunopharmacol., v. 1, n. 1567-5769 LA-eng PT-Journal Article RN-0 (AntiInflammatory Agents, Non-Steroidal) RN-0 (Cytokines) RN-0 (Enzyme Inhibitors) RN-0 (Fluorescent Dyes) RN-0 (Indicators and Reagents) RN-0 (RNA, Messenger) RN-0 (Tetracyclines) RN-10102-43-, p. 1765-1776, 2001 b.

DARSHAN, S.; DORESWAMY, R. Patented antiinflammatory plant drug development from traditional medicine. Phytotherapy Research, v. 18, n. 5, p. 343-357, 2004.

DAVID, V. Aplicação de técnicas cromatográficas na separação e determinação de triterpenos e hidrocarbonetos presents nas flores, frutos e xilopódio de Pouteria torta. [s.l: s.n.].

DE MELO, A. S. et al. IL-10 and IFN- $\gamma$ gene expression in chronic Chagas disease patients after in vitro stimulation with recombinant antigens of Trypanosoma cruzi. Cytokine, v. 58, n. 2, p. 207-212, 2012.

DE PAULA ROGERIO, A. et al. The role of lipids mediators in inflammation and resolution. BioMed research international, v. 2015, p. 605959, 2015.

DEL PRETE, A. A. A. P. S. G. F. R. C. M. ET. Molecular pathways in cancer-related inflammation. Biochemia Medica, p. 264-275, 2011.

DONNO, D. et al. Biomolecules and natural medicine preparations: Analysis of new sources of bioactive compounds from Ribes and Rubus spp. buds. Pharmaceuticals, v. 9, n. 1, p. 1$13,2016$.

DRAGHICIU, O. et al. Myeloid derived suppressor cells - An overview of combat strategies to increase immunotherapy efficacy Myeloid derived suppressor cells - An overview of combat strategies to increase immunotherapy ef fi cacy. n. October, p. 1-10, 2015.

E., Q. C. A. C. . C. C. Estudos Taxonômicos de Pouteria Aublet (Sapotaceae) para o Estado da Bahia, Brasil. 2 1, n. 1863, p. 36-39, 2010.

ELIAS SILVIA T, SALLES PALOMA M, DE PAULA JOSÉ E, SIMEONI LUIZ A, SILVEIRA DÂMARIS, GUERRA ELIETE N.S, M. A. B. Cytotoxic effect of Pouteria torta leaf extracts on human oral and breast carcinomas cell lines. Journal of cancer research and therapeutics, v. 9, n. 4, p. 601-606, 2013.

ELMANN, A. et al. Anti-neuroinflammatory effects of the extract of Achillea fragrantissima. BMC complementary and alternative medicine, v. 11, p. 98, 2011.

FERREIRA, L. C. et al. Anti-inflammatory and antinociceptive activities of Campomanesia adamantium. Journal of Ethnopharmacology, v. 145, n. 1, p. 100-108, 2013. 
FICHTNER-FEIGL, S. et al. Cytokines Mediating the Induction of Chronic Colitis and Colitis- Mucosal Immunol Associated Fibrosis. v. 1, n. 0 1, p. 1-9, 2008.

FILHO, V. C.; YUNES, R. A. Estratégias para a obtenção de compostos farmacologicamente ativos a partir de plantas medicinais. Conceitos sobre modificação estrutural para otimização da atividade. Quimica Nova, v. 21, n. 1, p. 99-105, 1998.

\section{FLAVELL, D. J. ET AL. COMPARISON OF THE PERFORMANCE OF ANTI-CD7} IMMUNOTOXINS FOR THE DELIVERY OF SAPORIN TO. v. 13, n. Abril, p. 185-200, 1995.

FONTES JÚNIOR EA, SOUZA PJ, NASCIMENTO JL, SANTOS SN, ESPINDOLA LS, F. V. Antinociceptive and antiinflammatory properties of the ethanolic extract of Pouteria ramiflora roots. Lat Am J Pharm, v. 28, n. 6, p. 812-818, 2009.

FÜRST, R.; ZÜNDORF, I. Plant-derived anti-inflammatory compounds: Hopes and disappointments regarding the translation of preclinical knowledge into clinical progress. Mediators of Inflammation, v. 2014, 2014.

GAMA, L. U.; BARBOSA, A. A. A.; OLIVEIRA, P. E. A. M. Sistema sexual e biologia floral de Pouteria ramiflora e $P$. torta (Sapotaceae). Revista Brasileira de Botânica, v. 34, n. 3, p. 375-387, 2011.

GREEN, L. C.; LUZURIAGA, K. R.; WAGNER, D. A.; RAND, W.; ISTFAN, N.; YOUNG, V.R.; TANNENBAUM, S. R. Nitrate biosynthesis in man. Proc. Natl. Acad. Sci. USA, v. 78, n. 12, p. 7764-7768, 1981.

HAMILTON, A. C. Medicinal plants, conservation and livelihoods. Biodiversity and Conservation, v. 13, n. 8, p. 1477-1517, 2004.

HANADA, T.; YOSHIMURA, A. Regulation of cytokine signaling and inflammation. Cytokine and Growth Factor Reviews, v. 13, n. 4-5, p. 413-421, 2002.

HASSOUN, M.; REDDY, S. P. Hyperoxia-Induced Acute Lung Injury and. v. 182, n. 11, p. $1-18,2010$.

HEADLAND, S. E.; NORLING, L. V. The resolution of inflammation : Principles and challenges. Seminars in Immunology, 2015.

HEIFETS, L. Centennial of Metchnikoff's discovery. Journal of the Reticuloendothelial Society, v. 31, n. 5, p. 381-391, maio 1982.

HOEFER, I. E. et al. Aspirin, but not clopidogrel, reduces collateral conductance in a rabbit model of femoral artery occlusion. Journal of the American College of Cardiology, v. 46, n. 6, p. 994-1001, 2005.

IOANNIDOU, A.; GOULIELMAKI, E.; GARINIS, G. A. DNA Damage: From Chronic Inflammation to Age-Related Deterioration. Frontiers in Genetics, v. 7, n. October, p. 1-8, 2016.

JACOBS, J. F. M. et al. Antigen excess in modern immunoassays: To anticipate on the unexpected. Autoimmunity Reviews, v. 14, n. 2, p. 160-167, 2015. 
JOUNG, E.-J. et al. Anti-inflammatory effect of ethanolic extract from Myagropsis myagroides on murine macrophages and mouse ear edema. BMC complementary and alternative medicine, v. 12, n. 1, p. 171, 2012.

JUNG, H. W. et al. Hexane fraction of Zingiberis Rhizoma Crudus extract inhibits the production of nitric oxide and proinflammatory cytokines in LPS-stimulated BV2 microglial cells via the NF-kappaB pathway. Food and Chemical Toxicology, v. 47, n. 6, p. 11901197, 2009.

KENNETH L. ROCK, EICKE LATZ, FERNANDO ONTIVEROS, AND H. K. The sterile inflammatory response. n. 3, p. 321-342, 2010.

KIM, A.-R. et al. Isolation and identification of phlorotannins from Ecklonia stolonifera with antioxidant and anti-inflammatory properties. Journal of agricultural and food chemistry, v. 57, n. 9, p. 3483-3489, maio 2009.

KIM, H. J.; PARK, G. M.; KIM, J.-K. Anti-inflammatory effect of pristimerin on lipopolysaccharide-induced inflammatory responses in murine macrophages. Archives of pharmacal research, v. 36, n. 4, p. 495-500, 2013.

KIM, S.-H. et al. Discoidin domain receptor 1 mediates collagen-induced nitric oxide production in J774A.1 murine macrophages. Free radical biology \& medicine, v. 42, n. 3, p. 343-52, 2007.

KORHONEN, R. et al. Nitric oxide production and signaling in inflammation. Current drug targets. Inflammation and allergy, v. 4, n. 4, p. 471-479, ago. 2005.

KUMAR V, ABBAS A. K., A. J. C. Inflammation and repair. [s.l: s.n.].

LASKIN,DEBRA L. AND PENDINO, K. 1. MACROPHAGES AND INFLAMMATORY MEDIATORS IN TISSUE INJURY. Pharmacol. Toxicol, v. 0, p. 597-603, 1995.

LAWRENCE, T.; WILLOUGHBY, D. A; GILROY, D. W. Anti-inflammatory lipid mediators and insights into the resolution of inflammation. Nature reviews. Immunology, v. 2, n. 10, p. 787-95, 2002.

LEVY, B. D. et al. Lipid mediator class switching during acute inflammation: signals in resolution. Nature immunology, v. 2, n. 7, p. 612-619, 2001.

LIBBY, P.; RIDKER, P. M.; HANSSON, G. K. Inflammation in Atherosclerosis. From Pathophysiology to Practice. Journal of the American College of Cardiology, v. 54, n. 23, p. 2129-2138, 2009.

LOKAU, J.; AGTHE, M.; GARBERS, C. Generation of Soluble Interleukin-11 and Interleukin-6 Receptors: A Crucial Function for Proteases during Inflammation. Mediators of Inflammation, v. 2016, 2016.

LORENZI, H. Árvores brasileiras: manual de identificação e cultivo de plantas arbóreas do Brasil. Nova Odessa: Editora Plantarum, 1992.

LUNDVIG, D. M. S.; IMMENSCHUH, S.; WAGENER, F. A. D. T. G. Heme oxygenase, inflammation, and fibrosis: The good, the bad, and the ugly? Frontiers in Pharmacology, v. 
3 MAY, n. May, p. 1-14, 2012.

MA, J. et al. Analysis of polyphenolic antioxidants from the fruits of three Pouteria species by selected ion monitoring liquid chromatography-mass spectrometry. Journal of Agricultural and Food Chemistry, v. 52, n. 19, p. 5873-5878, 2004.

MALIK, Z. A. et al. Ethnomedicinal plants traditionally used in health care practices by inhabitants of Western Himalaya. Journal of Ethnopharmacology, v. 172, p. 133-144, 2015.

MANI SENTHIL KUMAR, K. T. et al. Anti-inflammatory activity of Acanthus ilicifolius. Journal of Ethnopharmacology, v. 120, n. 1, p. 7-12, 2008.

MARKS-KONCZALIK, J.; CHU, S. C.; MOSS, J. Cytokine-mediated Transcriptional Induction of the Human Inducible Nitric Oxide Synthase Gene Requires Both Activator Protein 1 and Nuclear Factor א B-binding Sites *. v. 273, n. 35, p. 22201-22208, 1998.

MATTANA, C. M. ET AL. Evaluation of cytotoxicity and genotoxicity of Acacia aroma leaf extracts. TheScientificWorldJournal, v. 2014, p. 380-850, 2014.

MATTILA, J. T.; THOMAS, A. C. Nitric oxide synthase: Non-canonical expression patterns. Frontiers in Immunology, v. 5, n. OCT, p. 1-5, 2014.

MERESSE, B.; MALAMUT, G.; CERF-BENSUSSAN, N. Celiac Disease: An Immunological Jigsaw. Immunity, v. 36, n. 6, p. 907-919, 2012.

MÓCSAI, A.; WALZOG, B.; LOWELL, C. A. Intracellular signalling during neutrophil recruitment. Cardiovascular Research, v. 107, n. 3, p. 373-385, 2015.

MONCADA, S., FERREIRA, S. H. AND VANE, J. R. Prostaglandins, aspirin-like drugs and the oedema of inflammation. Nature, v. 246, p. 217-219, 1973.

MONTENEGRO, L. H. M. et al. Terpenóides e avaliação do potencial antimalárico, larvicida, anti-radicalar e anticolinesterásico de Pouteria venosa (Sapotaceae). Revista Brasileira de Farmacognosia, v. 16, n. suppl, p. 611-617, 2006.

MUNIĆ, V. et al. Intensity of macrolide anti-inflammatory activity in J774A.1 cells positively correlates with cellular accumulation and phospholipidosis. Pharmacological Research, v. 64, n. 3, p. 298-307, 2011.

MURAKAMI, A. et al. Suppressive effects of Okinawan food items on free radical generation from stimulated leukocytes and identification of some active constituents: implications for the prevention of inflammation-associated carcinogenesis. Asian Pacific journal of cancer prevention : APJCP, v. 6, n. 4, p. 437-448, 2005.

MYERS, N. et al. Biodiversity hotspots for conservation priorities. Nature, v. 403, n. 6772, p. 853-858, fev. 2000.

NAPOLITANO, D. R. et al. Down-modulation of nitric oxide production in murine macrophages treated with crude plant extracts from the Brazilian Cerrado. Journal of Ethnopharmacology, v. 99, n. 1, p. 37-41, 2005. 
NETEA, M. G.; QUINTIN, J.; VAN DER MEER, J. W. M. Trained immunity: A memory for innate host defense. Cell Host and Microbe, v. 9, n. 5, p. 355-361, 2011.

NEWMAN, D. J.; CRAGG, G. M. Natural Products as Sources of New Drugs from 1981 to 2014. Journal of Natural Products, v. 79, n. 3, p. 629-661, 2016.

NEWMAN, D. J.; CRAGG, G. M.; SNADER, K. M. The influence of natural products upon drug discovery. Natural product reports, v. 17, n. 3, p. 215-234, jun. 2000.

NGUTA, J. M. et al. Antimycobacterial and cytotoxic activity of selected medicinal plant extracts. Journal of Ethnopharmacology, v. 182, p. 10-15, 2016.

NUNEMAKER, C. S. Considerations for Defining Cytokine Dose, Duration, and Milieu That Are Appropriate for Modeling Chronic Low-Grade Inflammation in Type 2 Diabetes.

Journal of Diabetes Research, v. 2016, p. 1-9, 2016.

OKIN, D.; MEDZHITOV, R. Evolution of inflammatory diseases. Current Biology, v. 22, n. 17, p. 733-740, 2012.

OKSMAN-CALDENTEY, K. M.; INZÉ, D. Plant cell factories in the post-genomic era: New ways to produce designer secondary metabolites. Trends in Plant Science, v. 9, n. 9, p. 433440, 2004.

PAN, L.; CHAI, H.-B.; KINGHORN, A. D. Discovery of new anticancer agents from higher plants. Frontiers in bioscience (Scholar edition), v. 4, p. 142-56, 2012.

PARK, S. B. et al. Anti-inflammatory effect of a selective $11 \beta$-hydroxysteroid dehydrogenase type 1 inhibitor via the stimulation of heme oxygenase-1 in LPS-activated mice and J774.1 murine macrophages. Journal of Pharmacological Sciences, v. 131, n. 4, p. 241-250, 2016.

PARK, S. Y. et al. Induction of heme oxygenase-1 expression by cilostazol contributes to its anti-inflammatory effects in J774 murine macrophages. Immunology Letters, v. 136, n. 2, p. 138-145, 2011.

PASERO, G.; MARSON, P. Piccola storia della terapia antireumatica. II. L'aspirina. Reumatismo, v. 62, n. 2, p. 148-156, 2010.

PATRONO, C.; ROCCA, B. Aspirin, 110 years later. Journal of Thrombosis and Haemostasis, v. 7, n. SUPPL. 1, p. 258-261, 2009.

PENNINGTON TD, GARDENS RB, G. K. The genera of Sapotaceae: Royal Botanic Gardens, Kew New York Botanical Garden, Bronx; 1991.

PERFEITO, J. P. . S. M. L. . L. K. S. E. . P. J. E. . S. D. Characterization and biological properties of Pouteria torta extracts : v. 15, n. 3, p. 183-186, 2005.

PERKINS, J. Acute and chronic inflammation. [s.l: s.n.].

POLITO, L. et al. Plants Producing Ribosome-Inactivating Proteins in Traditional Medicine. Molecules (Basel, Switzerland), v. 21, n. 11, nov. 2016.

PRAVEEN RAO, P. N.; KNAUS, E. E. Evolution of nonsteroidal anti-inflammatory drugs 
(NSAIDs): Cyclooxygenase (COX) inhibition and beyond. Journal of Pharmacy and Pharmaceutical Sciences, v. 11, n. 2, p. 81-110, 2008.

PRUIMBOOM, L.; RAISON, C. L.; MUSKIET, F. A. J. Physical Activity Protects the Human Brain against Metabolic Stress Induced by a Postprandial and Chronic Inflammation. Behavioural Neurology, v. 2015, 2015.

PUNTUREE, K.; WILD, C. P.; VINITKETKUMNEUN, U. Thai medicinal plants modulate nitric oxide and tumor necrosis factor-?? in J774.2 mouse macrophages. Journal of Ethnopharmacology, v. 95, n. 2-3, p. 183-189, 2004.

PYEE, Y. et al. Suppression of inflammatory responses by handelin, a guaianolide dimer from chrysanthemum boreale, via downregulation of NF- $\kappa$ B signaling and pro-inflammatory cytokine production. Journal of Natural Products, v. 77, n. 4, p. 917-924, 2014.

RANGEL, T. F. L. V. B. et al. Human development and biodiversity conservation in Brazilian Cerrado. Applied Geography, v. 27, n. 1, p. 14-27, 2007.

RATES, S. M. Plants as source of drugs. Toxicon : official journal of the International Society on Toxinology, v. 39, n. 5, p. 603-613, maio 2001.

RATTER, J. A.; RIBEIRO, J. F.; S., B. The Brazilian Cerrado Vegetation and Threats to its Biodiversity. Annals of Botany, v. 80, p. 223-230, 1997.

RECIO, M. C.; ANDUJAR, I.; RIOS, J. L. Anti-inflammatory agents from plants: progress and potential. Current medicinal chemistry, v. 19, n. 14, p. 2088-2103, 2012.

REPETTO, G.; DEL PESO, A.; ZURITA, J. L. Neutral red uptake assay for the estimation of cell viability/cytotoxicity. Nature protocols, v. 3, n. 7, p. 1125-31, 2008.

RIBEIRO, D.; FREITAS, M.; LIMA, J.L.F.C.; FERNANDES, E. Proinflammatory Pathways: The Modulation by Flavonoids. Medicinal Research Reviews, v. 35, p. 877-936, 2015.

ROBINSON, M. M.; ZHANG, X. the World Medicines Situation 2011 Traditional Medicines : Global Situation, Issues and Challenges. World Health Organization, n. 3rd Edition, p. 1-14, 2011.

ROJO, L. E. et al. NIH Public Access. v. 9, n. 3, p. 185-195, 2014.

RUDDLE, N. H. High Endothelial Venules and Lymphatic Vessels in Tertiary Lymphoid Organs: Characteristics, Functions, and Regulation. Frontiers in Immunology, v. 7, n. November, p. 1-7, 2016.

SCOTECE, M. et al. Further evidence for the anti-inflammatory activity of oleocanthal: Inhibition of MIP-1 $\alpha$ and IL-6 in J774 macrophages and in ATDC5 chondrocytes. Life Sciences, v. 91, n. 23-24, p. 1229-1235, 2012.

SCOTT, A. What is "inflammation"? Are we ready to move beyond Celsus? British Journal of Sports Medicine, v. 38, n. 3, p. 248-249, 2004.

SERHAN, C. N. et al. Lipid Mediators in the Resolution of Inflammation. Cold Spring 
Harbor Perspectives in Biology, p. 1-21, 2014.

SHAHBAZI, S. et al. Drug Targets for Cardiovascular-Safe Anti-Inflammatory: In Silico Rational Drug Studies. PloS one, v. 11, n. 6, p. e0156156, 2016.

SILVA, C. A. M.; SIMEONI, L. A.; SILVEIRA, D. Genus Pouteria : Chemistry and biological activity Revisão. v. 19, n. December 2008, p. 501-509, 2009.

SOLEIMANPOUR, M. et al. The Role of Non-Steroidal Anti-Inflammatory Drugs (NSAIDs) in the Treatment of Patients With Hepatic Disease: A Review Article. Anesth Pain Med, v. 6, n. 4, 2016.

SOUZA, P. M. et al. Plants from Brazilian Cerrado with Potent Tyrosinase Inhibitory Activity. PLoS ONE, v. 7, n. 11, p. 1-7, 2012.

SWENSON, U.; ANDERBERG, A. A. Phylogeny, character evolution, and classification of Sapotaceae (Ericales). Cladistics, v. 21, n. 2, p. 101-130, 2005.

TABORDA, C. P. et al. More is not necessarily better: prozone-like effects in passive immunization with IgG. Journal of immunology (Baltimore, Md. : 1950), v. 170, n. 7, p. 3621-3630, 2003.

TAKEUCHI, O.; AKIRA, S. Pattern Recognition Receptors and Inflammation. Cell, v. 140, n. 6, p. 805-820, 2010.

\section{TEOTÔNIO, I. Efeitos Anti-Inflamatórios de Espécies de Pouteria spp. sobre} Macrófagos Murinos RAW 264.7 Estimulados com LPS. [s.1.] Universidade de Brasília, 2015.

VALLIÈRES, M.; DU SOUICH, P. Modulation of inflammation by chondroitin sulfate. Osteoarthritis and Cartilage, v. 18, n. SUPPL. 1, p. 18-23, 2010.

VAN TONDER, A.; JOUBERT, A. M.; CROMARTY, A. D. Limitations of the 3-(4,5dimethylthiazol-2-yl)-2,5-diphenyl-2H-tetrazolium bromide (MTT) assay when compared to three commonly used cell enumeration assays. BMC research notes, v. 8, p. 47, 2015.

VANE, J. R. Inhibition of prostaglandin synthesis as a mechanism of action for aspirin-like drugs. Nature: New biology, v. 231, n. 25, p. 232-235, jun. 1971.

VANE, J. R. The fight against rheumatism: from willow bark to COX-1 sparing drugs. J Physiol Pharmacol, v. 51, p. 573-586, 2000.

VERES, B. Anti-Inflammatory Role of Natural Polyphenols and Their Degradation Products. Severe Sepsis and Septic Shock - Understanding a Serious Killer, p. 379-410, 2012.

WALTENBERGER, B. et al. Natural products to counteract the epidemic of cardiovascular and metabolic disorders. Molecules, v. 21, n. 6, p. 1-33, 2016.

WANG, Z. Imaging Nanotherapeutics in Inflamed Vasculature by Intravital Microscopy. Theranostics, v. 6, n. 13, p. 2431-2438, 2016.

WHITTAKER, R. J.; WILLIS, K. J.; FIELD, R. Scale and species richness : towards a 
general, theory of species diversity hierarchical. Diversity, v. 28, n. 4, p. 453-470, 2001.

WONG, E. H. J. et al. Comparative Genomics Revealed Multiple Helicobacter pylori Genes Associated with Biofilm Formation In Vitro. Plos One, v. 11, n. 11, p. e0166835, 2016.

WU, F. et al. The Role of Interleukin-17 in Lung Cancer. Mediators of Inflammation, v. 2016, p. 1-6, 2016.

YING, X. et al. Piperine inhibits LPS induced expression of inflammatory mediators in RAW 264.7 cells. Cellular immunology, v. 285, n. 1-2, p. 49-54, 2013.

YUAN, Q. et al. Ethanol extract of Adiantum capillus-veneris L. suppresses the production of inflammatory mediators by inhibiting NF- $\kappa$ B activation. Journal of Ethnopharmacology, $v$. 147, n. 3, p. 603-611, 2013.

ZILTENER, J. L.; LEAL, S.; FOURNIER, P. E. Non-steroidal anti-inflammatory drugs for athletes: An update. Annals of Physical and Rehabilitation Medicine, v. 53, n. 4, p. 278$288,2010$. 